\title{
MARBURY V. MADISON Y LOS MITOS ACERCA DEL CONTROL JUDICIAL DE CONSTITUCIONALIDAD
}

\section{Manuel José García-Mansilla}

Facultad de Derecho, Universidad Austral

MGarciaMansilla@austral.edu.ar

Recibido: $1 / 4 / 2020$

Aceptado: $11 / 5 / 2020$

A page of history is worth a volume of logic. Oliver Wendell Holmes ${ }^{1}$

\section{Resumen}

Este trabajo propone revisar ciertos mitos acerca del rol que habrían tenido tanto el Chief Justice John Marshall como su decisión en el fallo Marbury v. Madison en relación con el origen del control judicial de constitucionalidad.

Palabras clave: Marbury v. Madison, John Marshall, control judicial de constitucionalidad, constitución, deber judicial.

\section{Marbury v. Madison and the myths about judicial review}

\begin{abstract}
This article proposes a review of certain myths about the alleged role that both Chief Justice John Marshall and his decision at Marbury v. Madison had in connection with the origins of judicial review.
\end{abstract}

Key words: Marbury v. Madison, John Marshall, judicial review, constitution, judicial duty.

\footnotetext{
* Agradezco a Alberto F. Garay, Alberto B. Bianchi, Antonio María Hernández, Carlos Laplacette, José Sebastián Elías, Alfonso Santiago, Ignacio Colombo Murúa, Pedro Caminos, Juan Bautista Etcheverry, Jerónimo Lau Alberdi, Iván Vigani, Gregorio Uriburu y Ricardo Ramírez Calvo, quienes leyeron borradores de este trabajo y me hicieron valiosos comentarios, críticas y sugerencias. Por supuesto, soy el único responsable de los errores que el trabajo pueda tener.

1 New York Trust Co. v. Eisner, 256 U.S. 345, p. 349 (1921).
} 


\section{Introducción}

John Marshall no inventó el control judicial de constitucionalidad. 1803 tampoco fue el año en el que por primera vez un tribunal ejerció el control de constitucionalidad de una ley federal en los Estados Unidos. La Suprema Corte estadounidense no se "autoasignó" (ni, mucho menos, "usurpó") esa facultad en el caso Marbury v. Madison. ${ }^{2}$ Y la judicial review no es un ejemplo de "creación” pretoriana de sus jueces (que tampoco esperaron más de cincuenta años para declarar inconstitucional, por segunda vez, una ley del Congreso en el también famoso caso Dred Scott v. Sanford). ${ }^{3}$ Sin embargo, esto es lo que, con mayor o menor énfasis, se suele enseñar año tras año en muchas facultades de derecho, no solo en la Argentina, sino en varios países del mundo. Así es que a través de un proceso mecánico de repetición, tanto el rol de John Marshall como el del caso Marbury v. Madison renuevan el estatus de verdades indiscutibles en relación con los orígenes del control judicial de constitucionalidad en el constitucionalismo moderno. Pero se trata, lisa y llanamente, de un conjunto de mitos y errores históricos que conviene revisar de raíz.

La fuerza de lo que, en conjunto, podríamos llamar "el mito de Marbury", con sus diversas variantes o modulaciones, es evidente. Cualquiera que repase diversas obras jurídicas publicadas en castellano, sean tanto clásicas como modernas, podrá encontrar frases como estas:

«Marbury v. Madison» es la decisión más importante del derecho constitucional americano y, sin duda, un fallo que ha influido en nuestro derecho constitucional y en todo el sistema de control de constitucionalidad. Establece la autoridad para el Poder Judicial de revisar la constitucionalidad de los actos de los poderes Legislativo y Ejecutivo. A pesar de que la Constitución guarda silencio sobre si los tribunales federales tienen esta autoridad, esta competencia ha existido prácticamente sin disputa desde que el Chief Justice Marshall diera su opinión en el caso Marbury en 1803. (Sola, 2001, p. 187)

[L]a competencia judicial para comprobar la constitucionalidad de la legislación emitida por el Congreso apareció en la joven República [estadounidense] durante el primer cuarto del siglo XIX, y fue una consecuencia de los esfuerzos del Chief Justice John Marshall para extender la jurisdicción federal. Los jueces se convirtieron de esta manera en un verdadero tercer poder; fenómeno este sin precedente histórico [...]. (Loewenstein, 1964, p. 310) ${ }^{4}$

25 U.S. (1 Cranch) 137 (1803).

360 U.S. (19 How.) 393 (1857).

4 Según Loewenstein (1964), se trataría de un "derecho de los tribunales" que habría sido "asumido, usurpado o implícitamente otorgado” (p. 308). 
Desde entonces, desde esa capital sentencia de 1803, la judicial review, entendida como control judicial sobre la constitucionalidad de las leyes, va a desarrollarse y va a concluir siendo una pieza central del sistema [...]. ¿Cómo explicar la sorprendente aceptación general de una institución cuya posición central está basada enteramente en una competencia, la de judicial review, que no ha sido atribuida expresamente por la Constitución, sino propiamente "usurpada", o al menos, autoatribuida? (García de Enterría, 2006, p. 135) ${ }^{5}$

El leading case «Marbury c/ Madison», del año 1803, ha sido el antecedente inmediato en Estados Unidos de la doctrina de la supremacía y del control constitucionales, y con su ejemplaridad suscitó el seguimiento o imitación dentro y fuera de Estados Unidos. De allí se trasplantó a nuestro derecho. (Bidart Campos, 2005, p. 336) ${ }^{6}$

Luego de arrogarse la atribución de no aplicar las leyes anticonstitucionales, la Corte Suprema la ejercitó con tanta moderación que transcurrió más de medio siglo sin que otra ley del Congreso fuera rechazada por el tribunal. Ello aconteció en 1857, en otro caso famoso, el de Dred Scott v. Sanford [...]. (Bidegain, 1994, p. 127) ${ }^{7}$

Montesquieu -a todo evento, el ideólogo de la división de poderes- decía en El espiritu de las leyes (LIV, XI, Cap. VI) que los jueces eran la bouche qui prononuce [sic] les paroles de la loi: "la boca que pronuncia las palabras de la ley, seres inanimados que no pueden moderar la fuerza de ésta ni su rigor”. Marshall, en cambio, da vuelta el paradigma, inventa lo que hoy conocemos como "activismo" judicial y afirma enfáticamente que son los jueces los que deben decir qué cosa es la ley. (Arballo, 2003, p. 848)

Lo realmente notable de este fallo desde el punto de vista político es cómo la Corte renunció a ejercer un posible poder en un caso concreto -en una situación en la que el mismo Marshall estaba involucrado ipuesto que él había emitido las comisiones [de designación de jueces de paz] como Secretario de Estado de Adams!-, dado que de lo contrario hubiera generado un conflicto de poderes del que seguramente habría salido debilitada, pero a través de un argumento que implicaba autoasignarse un poder mucho más general, permanente y profundo. (Nino, 2004, pp. 663-664) ${ }^{9}$

5 Énfasis agregado.

6 Bidart Campos (2005) destaca que el control de constitucionalidad cobró "vigencia sociológica" a través de "fuente judicial" (p. 337).

7 Énfasis agregado.

8 Énfasis agregado. Arballo (2003) advierte que "tanta insistencia en el poder de la Corte (que ésta, en verdad, se autoarrogaba) era en realidad una advertencia a los otros poderes que trascendía el asunto que se estaba decidiendo" (p. 849). Énfasis agregado.

9 Énfasis agregado. 
«Marbury v. Madison» es -sin lugar a duda- el caso más famoso del constitucionalismo moderno, y todos los profesores de derecho constitucional nos referimos a él para explicar el nacimiento del control judicial de constitucionalidad sobre los actos de los poderes políticos del Estado. (Amaya, 2017, p. X) ${ }^{10}$

Los ejemplos con citas similares podrían multiplicarse (probablemente, por cientos). Y es que la historia oficial, de ribetes míticos, es francamente seductora: la Constitución de los Estados Unidos, se afirma, no contemplaba la judicial review. Frente a un conflicto por la designación de los llamados "jueces de la medianoche", ${ }^{11}$ que dejaba a la Suprema Corte estadounidense en una difícil encrucijada política, el Chief Justice Marshall inventó la judicial review. Y lo hizo ¡a pesar de no ser abogado! Con esa jugada política y jurídica magistral, Marsha11 permitió al tribunal salir airoso de la encerrona a la que había sido sometido por el presidente Thomas Jefferson. El nuevo Presidente había dado señales de que no iba a acatar la eventual decisión de la Corte de hacer cumplir con la entrega de la designación formal de William Marbury como juez de paz firmada por el presidente saliente, John Adams, horas antes de abandonar el cargo. Y mucho más importante que eludir a Jefferson fue que su sentencia permitió que los jueces federales se autoasignaran una facultad constitucional decisiva que no estaba expresamente reconocida en la Constitución de 1787, pero que, sin embargo, terminaría siendo la clave de bóveda del sistema constitucional de cuño estadounidense. ${ }^{12}$ Tan radical fue la contribución de Marshall a través de la creación de la judicial review en 1803 que, por prudencia, la Corte tuvo que esperar más de medio siglo para poder volver a ejercer su función más importante. Y, cuando lo hizo, ayudó a desatar la Guerra Civil norteamericana con el infame caso Dred Scott.

La repetición de esta verdadera fábula histórica, especialmente por gran parte de la doctrina en el ámbito hispano parlante, ${ }^{13}$ tiene varias explicaciones. Me

10 Énfasis agregado. Amaya (2017) aclara, sin embargo, que sería incorrecto sostener que la judicial review nació "a partir del genio de Marshall" (p. 1).

11 Los pormenores del caso pueden consultarse en Hobson (1996, pp. 47-58).

12 Por todos, ver Sola (2001, pp. 189-192).

13 Entre las excepciones, destaco a Linares Quintana y a Bianchi. Linares Quintana (1978) recopila antecedentes estatales y federales sobre el control judicial de constitucionalidad en los Estados Unidos y advierte, ya en 1978, que "muchos comentaristas han señalado la falta de originalidad del pronunciamiento judicial recaído en el caso Marbury v. Madison" (p. 381). De forma similar, Bianchi (1992) advertía años después que la sentencia de Marshall no era original: "Si bien no caben dudas que la decisión de Marshall en 'Marbury' marca un hito decisivo en la historia del control judicial de constitucionalidad, no menos cierto es, también, que no se trata de una elaboración enteramente original” (p. 62). 
limitaré a exponer las dos que creo pueden ser las más importantes. Por un lado, se trata de una postura que durante casi todo el siglo XX, si bien con diversos matices, adquirió el carácter de historia oficial y ortodoxa en los Estados Unidos. La mayoría de los estudios clásicos en la materia repetían una explicación que parecía indiscutible en el mundo anglosajón. ${ }^{14}$ Más allá de la duda que podría asaltar, por ejemplo, a cualquiera que leyera El Federalista $\mathrm{N}^{\circ} 78$ de Alexander Hamilton publicado en 1788, lo cierto es que la doctrina estadounidense sostuvo durante gran parte del siglo XX esta historia prácticamente sin excepciones. Por el otro, los numerosos estudios académicos que fueron cuestionando y corrigiendo estos errores históricos que forman parte del mito de Marbury, especialmente los publicados durante los últimos veinte años en los Estados Unidos, no han tenido la necesaria difusión y atención en los países de habla hispana. ${ }^{15}$

En este trabajo intentaré exponer esos cuestionamientos doctrinarios al mito de Marbury, así como analizar su impacto en el ámbito académico estadounidense. Para poner en contexto la importancia de esta doctrina, hoy mayoritaria, voy a estructurar el trabajo en cuatro partes. En la primera, necesariamente más extensa, haré una revisión de las evidencias históricas que permiten cuestionar de raíz el mito de Marbury. En la segunda, explicaré en qué contexto nacieron la leyenda y los mitos alrededor de Marbury v. Madison. En la tercera, haré una referencia a las revisiones y críticas que se hicieron al mito desde distintas ópticas en los Estados Unidos, en especial durante los últimos veinte años. En la cuarta parte, explicaré por qué creo que es tan importante corregir la historia oficial que nutre el mito de Marbury en cuanto a los orígenes del control judicial de constitucionalidad. Finalmente, daré mis conclusiones.

\section{Desmitificando a Marbury v. Madison}

\subsection{John Marshall no inventó el control judicial de constitucionalidad}

A pesar de la pretendida autoría de Marshall, las referencias anteriores a 1803 acerca del deber de los jueces federales de declarar la inconstitucionalidad de las leyes del Congreso que contradigan la Constitución, lejos de ser escasas, son

14 Entre otros, ver Bickel (1962, p. 1) ("[T]he institution of the judiciary needed to be summoned up out of the constitutional vapors, shaped and maintained; the Great Chef Justice, John Marshall was there to do it and did. If any social process can be said to have been 'done' at a given time and by a given act, it is Marshall's achievement. The time was 1803; the act was the decision in the case of Marbury v. Madison").

15 Entre las excepciones en cuanto a la difusión y análisis de algunos de esos trabajos académicos modernos, ver, entre otros, Ahumada Ruiz (2006), Fernández Segado (2011) y Laplacette (2016). 
abrumadoras. Muchos años antes de que el gran Chief Justice se sentara a escribir su sentencia en Marbury v. Madison, los principales hombres públicos más influyentes en los Estados Unidos, en especial convencionales constituyentes, jueces y abogados, ya habían defendido ese rol por parte del Poder Judicial en numerosas oportunidades, tanto de forma pública como privada. Y lo hicieron con argumentos tan o más elaborados que los del propio Marshall. Sin pretensión de exhaustividad, destaco las siguientes:

\subsubsection{James Iredell}

Emigró desde Inglaterra a los Estados Unidos a los 17 años. Luego de estudiar derecho de forma privada, tuvo una destacada actuación en el estado de Carolina del Norte, en donde no solo ejerció la profesión, sino que ocupó diversos cargos públicos, incluidos los de juez en la Corte Superior estatal, Attorney General y compilador y revisor de las leyes del estado de Carolina del Norte. Iredell tuvo también una activa participación en la Convención de Carolina del Norte que intentó ratificar la Constitución en 1788. ${ }^{16}$ Posteriormente, sería designado por el presidente George Washington como Justice de la Suprema Corte el 8 de febrero de 1790. Ejerció ese cargo hasta su muerte, el 20 de octubre de 1799.

A pesar de su juventud, Iredell fue uno de los líderes intelectuales de la revolución en Carolina del Norte y un abogado de renombre en los Estados Unidos. Ya en septiembre de 1783, definía a la república como una forma de gobierno en la que "la Ley es superior a cualquiera o a todos los individuos, y la Constitución es superior incluso a la Legislatura, y de la cual los jueces son los guardianes y protectores" (Iredell, 1783, citado en Higginbotham, 1976, pp. 446-451). ${ }^{17}$

En 1786, defendió a Elizabeth Cornell Bayard en un conocido caso ante la Suprema Corte estatal. Allí, planteó la inconstitucionalidad de una ley local de 1785 que ordenaba desechar sumariamente los reclamos judiciales para intentar recobrar la propiedad en casos de confiscación bajo las Confiscation Acts de 1777 y 1779 . Ambas leyes permitían al Gobierno local quitarles todos los bienes a personas consideradas como leales al imperio británico y venderlas a un

16 Cfr. Connor (1912, p. 236).

17 La definición de la forma republicana de gobierno y el rol de los jueces está en la página 449, donde también defiende la permanencia en el cargo y la protección del salario de los jueces como mecanismos para garantizar su independencia. La traducción al castellano de la cita original en inglés es propia, al igual que todas las traducciones incluidas en este trabajo. 
tercero como método para solventar los costos de la guerra de independencia. Sin embargo, la constitución de Carolina del Norte establecía concretamente que toda controversia legal relacionada con la propiedad debía ser decidida mediante el juicio por jurados, al que se consideraba sagrado e inviolable. ${ }^{18}$ Samuel Cornell, el padre de la reclamante, sabiendo las consecuencias de la ley debido a su lealtad a Gran Bretaña, había legado a sus hijas todo su patrimonio antes de huir del estado de Carolina del Norte. A pesar de ello, las autoridades locales le confiscaron todos los bienes legados a una de sus hijas, Elizabeth, y se los vendieron a Spyres Singleton, un conocido político local. Con la ayuda de Iredell, Cornell Bayard inició una demanda para recuperar los bienes confiscados. Pero la ley estatal de 1785, contradiciendo directamente la constitución local, impedía que el reclamo fuera decidido a través del juicio por jurados. Los jueces se enfrentaban así a un obstáculo legislativo, teóricamente insalvable para considerar el caso.

La Suprema Corte estatal decidió demorar el estudio del planteo de inconstitucionalidad, previendo la posibilidad de que la legislatura local revisara la ley. Iredell aprovechó esa demora y publicó un artículo en los periódicos locales explicando que la ley era inconstitucional porque violaba la Constitución de Carolina del Norte de 1776. El artículo en cuestión, titulado "To the public", fue publicado el 17 de agosto de 1786 (McRee, 1858, pp. 145 y ss.). Allí, Iredell hizo una defensa pública del control judicial de constitucionalidad y, entre otras cosas, sostuvo:

No he vivido tan poco tiempo en el Estado, ni con tan poco interés sobre sus preocupaciones, como para olvidar la ansiedad extrema que nos agitaba a todos al formar la constitución, una constitución que considerábamos como la base fundamental de nuestro gobierno, inalterable, salvo por el mismo alto poder que la estableció, y que por lo tanto debíamos deliberar sobre ella con la mayor precaución, porque si contenía algún principio malvado, el gobierno formado bajo ella debía ser aniquilado antes de que el mal pudiera ser corregido. Por supuesto, había que considerar cómo imponer restricciones a la legislatura, que aunque la dejaran libre para todos los propósitos útiles, fueran al mismo tiempo

18 La sección XIV de la Declaración de Derechos de la Constitución de Carolina del Norte del 17 de diciembre de 1776 establecía: "That in all controversies at law, respecting property, the ancient mode of trial by jury is one of the best securities of the rights of the people, and ought to remain sacred and inviolable (The Constitution of North Carolina, adopted December 17, 1776; and the amendments thereto, submitted to the people by the convention which assembled at Raleigh, June 4, 1835; together with an ordinance for carrying the same into effect" (J. Gales \& Son, Raleigh, 1835, p. 4). 
una salvaguarda contra el abuso del poder ilimitado, en el que no se podía confiar, sin el peligro más inminente, para cualquier hombre o cuerpo de hombres en la tierra. (McRee, 1858, pp. 145-146)

\section{Iredell recordó que los revolucionarios estadounidenses aborrecían la omni- potencia legislativa del parlamento británico y explicó que:}

el poder de la Asamblea está limitado y definido por la constitución. Es una criatura de la constitución. [...] El pueblo ha elegido ser gobernado bajo tales y tales principios. No ha elegido ser gobernado, ni prometió someterse a ningún otro; y la Asamblea no tiene más derecho a ser obedecida en otros términos, que el que podría tener cualquier otro poder en la tierra a gobernarnos; porque hemos acordado tanto ser gobernados por el Diván Turco como por nuestra propia Asamblea General, únicamente bajo unos términos expresamente prescriptos. Hay consecuencias que parecen tan naturales, y de hecho tan irresistibles, que no observo que hayan sido mayormente cuestionadas. El gran argumento es que, aunque la Asamblea no tiene derecho a violar la constitución, si lo hace de hecho, el único remedio es, o una humilde petición para que se derogue la ley, o una resistencia universal del pueblo. Pero mientras tanto, su norma, sea cual fuere, debe ser obedecida como una ley; porque el poder judicial no debe atreverse a cuestionar el poder de una norma de la Asamblea. (McRee, 1858, pp. 146-147) ${ }^{19}$

\section{Luego de rechazar ambas posiciones, Iredell planteó:}

queda por averiguar si el poder judicial tiene alguna autoridad para interferir en tal supuesto. Entiendo que el deber de ese órgano en todos los casos es decidir de acuerdo con las leyes del Estado. Supongo que no se negará que la constitución es una ley del Estado, que es la ley fundamental, y que es inalterable por la legislatura, que deriva todo su poder de ella. Una ley de la Asamblea puede derogar otra ley de la Asamblea. Por esta razón, la ley posterior debe ser obedecida, y no la anterior. Una ley de la Asamblea no puede derogar la constitución, ni parte alguna de ella. Por esa razón, una ley de la Asamblea, inconsistente con la constitución, es nula y no puede ser obedecida, sin desobedecer a la ley superior a la que estábamos previa e irrevocablemente obligados. Los jueces, por lo tanto, deben tener el cuidado de que cada ley de la Asamblea que pretendan imponer esté autorizada por la constitución ya que, de lo contrario, corren el riesgo de actuar sin autoridad legal. Este no es un poder usurpado o discrecional, sino uno que inevitablemente resulta de la naturaleza de su cargo, ya que son jueces en beneficio de todo el pueblo, no meros servidores de la Asamblea. (McRee, 1858, p. 148)20

19 Énfasis en el original.

20 Énfasis en el original. 
A instancias de Iredell, en Bayard v. Singleton, ${ }^{21}$ en mayo de 1787, la Suprema Corte de Carolina del Norte declaró inconstitucional la ley de 1785 y ordenó que el caso prosiguiera y fuera decidido mediante un juicio por jurados conforme lo previsto en la Constitución estatal de 1776. Luego de resaltar la importancia de las obligaciones derivadas del juramento al asumir el cargo de juez, así como los deberes inherentes a la función judicial, el tribunal expuso lo siguiente:

Que, según la Constitución, cada ciudadano tenía indudablemente el derecho a una decisión sobre su propiedad mediante un juicio por jurados. Por eso, si la Legislatura pudiera quitarle este derecho y exigirle que enfrente una condena sobre su propiedad sin un juicio, podría con la misma autoridad requerir que le quiten la vida sin un juicio por jurados, y que deba ser condenado a morir, sin la formalidad de ningún juicio en absoluto: que si los miembros de la Asamblea General pudieran hacer esto, podrían con la misma autoridad, no solo convertirse en los Legisladores del Estado de por vida, sin más elecciones del pueblo, sino a partir de alli transmitir la dignidad y autoridad de la legislación a sus herederos varones para siempre. Pero que estaba claro que ninguna ley que pudieran aprobar podría derogar o alterar la Constitución de manera alguna, porque si pudieran hacerlo, al mismo tiempo destruirían su propia existencia como Legislatura y disolverían el gobierno allí establecido. En consecuencia, la Constitución (que el poder judicial estaba obligado a tener en cuenta como correspondía con cualquier otra ley), estando en plena vigencia como la ley fundamental del país, a pesar de la norma de la legislatura en la que se fundaba la moción actual, esa misma norma, por supuesto, debe quedar anulada y sin ningún efecto en esta ocasión. ${ }^{22}$

Bayard v. Singleton fue el primer caso en el que la Suprema Corte de Carolina del Norte declaró inconstitucional una ley estatal. Apenas conocida la decisión, Richard Dobbs Spaight, representante de Carolina del Norte en la Convención de Filadelfia, escribió a Iredell una crítica a la decisión de los jueces. ${ }^{23}$ Nue-

21 Bayard v. Singleton, 1 N.C. 5 (1787).

22 1 N.C. 5 , pp. 6-7.

23 "The late determination of our judges at Newbern, must, in my opinion, produce the most serious reflections in the breast of every thinking man, and of every well-wisher to his country. It cannot be denied, but that the Assembly have passed laws unjust in themselves, and militating in their principles against the Constitution, in more instances than one, and in my opinion of a more alarming and destructive nature than the one which the judges, by their own authority, thought proper to set aside and declare void. [...] I do not pretend to vindicate the law, which has been the subject of controversy: it is immaterial what law they have declared void; it is their usurpation of the authority to do it, that I complain of, as I do most positively deny that they have any such power; nor can they find any thing 
vamente, Iredell defendió ese rol de los jueces en una carta privada a Dobbs Spaight, fechada el 26 de agosto de 1787. Allí, expuso de nuevo casi todos los argumentos que John Marshall desarrollaría quince años después en Marbury:

En relación con la última decisión de [la Suprema Corte de Carolina del Norte] en Newbern, confieso que siempre ha sido mi opinión, que una ley incompatible con la Constitución era nula; y que los jueces, consistentemente con sus deberes, no podrían darle efecto. Me parece que la Constitución es una ley fundamental, que limita los poderes de la Legislatura, y que cada ejercicio de esos poderes debe, necesariamente, ser comparado con ella. [...] En un Gobierno republicano (tal como lo concibo), la libertad individual es una cuestión de suma importancia y, si no hay un control sobre las pasiones públicas, corre el mayor peligro. Al tener el poder en sus propias manos, la mayoría puede cuidarse a sí misma; pero ¿en qué condición están las minorías, si el poder del otro es ilimitado? Supongo que estas consideraciones, u otras similares, ocasionaron esas disposiciones expresas para la libertad personal de cada ciudadano, que los ciudadanos, cuando formaron la Constitución, eligieron reservar como un derecho inalienable, y no dejarlo a merced de ninguna Asamblea que sea. Esa restricción podría ser atendida con inconvenientes; pero decidieron arriesgarse a esas molestias, por el bien de la ventaja; y en cada transacción debemos actuar de la misma manera: debemos elegir entre males de uno u otro tipo: la imperfección del hombre nunca puede mantenerse completamente al margen de todo. Por lo tanto, siendo la Constitución una ley fundamental, y una ley por escrito de la naturaleza solemne que he mencionado [...], el poder judicial, en el ejercicio de su autoridad, debe tomar nota de ella como la base de su autoridad, así como de toda otra autoridad; y como ningún artículo de la Constitución puede ser derogado por una Legislatura, que deriva todo su poder de ella, se sigue que la ley fundamental e irrevocable debe ser obedecida, a través del rechazo de un acto injustificado e incompatible con ella, o usted debe obedecer un acto fundado en una autoridad que no fue otorgada por el pueblo, y a la cual, entonces, el pueblo no le debe obediencia. No es que los jueces hayan sido nombrados árbitros para determinar, como si lo fueran, en cualquier instancia, si la Asamblea ha violado o no la Constitución; pero cuando una ley se presenta necesariamente ante ellos al momento de resolver un caso, deben, inevitablemente, determinarlo de una forma u otra. [...] Realmente me parece que el ejercicio de ese poder es inevitable, dado que la Constitución no es un objeto meramente imaginario, sobre el cual se pueden formar diez mil opiniones diferentes, sino un documento escrito

in the Constitution, either directly or impliedly, that will support them, or give them any color of right to exercise that authority. Besides, it would have been absurd, and contrary to the practice of all the world, had the Constitution vested such powers in them, as they would have operated as an absolute negative on the proceedings of the Legislature, which no judiciary ought ever to possess" (carta de Richard Dobbs Spaight a James Iredell del 12 de agosto de 1787, en McRee, 1858, p. 169). 
al que todos pueden recurrir, y al que, en consecuencia, los jueces no pueden ignorar deliberadamente. (McRee, 1858, pp. 172-175)

Los argumentos de Iredell son muy similares a los que otros hombres públicos esgrimirán para defender el control judicial de constitucionalidad durante fines del siglo XVIII. ${ }^{24}$ Tanto el carácter de "ley fundamental" que se le reconoce a la constitución escrita, ${ }^{25}$ así como los límites del Poder Legislativo en cuanto a la imposibilidad de sancionar leyes que contradigan esa norma jurídica considerada de rango superior, sancionada por el pueblo y alterable solamente por él, y, fundamentalmente, el deber de los jueces de invalidar las leyes que violen la constitución, están presentes en todas esas argumentaciones. Lo mismo ocurre con la idea acerca del carácter subordinado que tenía el Poder Legislativo, cuya autoridad deriva de la constitución. Detrás de muchas de esas posturas hay también un profundo escepticismo y temor a eventuales abusos de poder por parte del Poder Legislativo. El deber de los jueces de ejercer el control de constitucionalidad sobre las leyes no se considera como un conflicto entre el Poder Judicial y el legislador, sino uno entre el legislador y la voluntad del pueblo expresada en la constitución. ${ }^{26}$

\subsubsection{James Wilson}

Emigró desde Escocia a los Estados Unidos a los 23 años. Fue una de las seis personas que firmaron tanto la Declaración de Independencia en 1776 como la Constitución de Filadelfia en 1787. ${ }^{27}$ Su influencia en la Convención Constituyente fue decisiva y estuvo casi a la par de la de James Madison. ${ }^{28}$ También tuvo una activa participación en el proceso de ratificación de la Constitución en el estado de Pennsylvania, que fue el segundo estado en ratificarla el 12 de diciembre de 1787 (Hall, 1998, p. 126).

Al defender junto con Madison la inclusión en el gobierno federal de un Consejo de Revisión con participación de los jueces y el Poder Ejecutivo para ejercer

24 Según Casto (2009, p. 398), el análisis y justificación del control de judicial de constitucionalidad escrito por Iredell fue el más exhaustivo de todos los intentados por un juez de la Suprema Corte en su historia.

25 Sobre el concepto de fundamental law y sus alcances, ver Hamburger (1989, pp. 254-265).

26 Cfr. Casto (1995, pp. 329 y ss.).

27 Los otros cinco fueron: George Clymer, Benjamin Franklin, Robert Morris, George Read y Roger Sherman.

28 Cfr. Farrand (1913, pp. 197-198). 
un control estricto de las leyes previo a su ejecución, Wilson tuvo oportunidad de referirse al control judicial de constitucionalidad en más de una ocasión. En la sesión del 21 de julio de 1787 de la Convención de Filadelfia, sostuvo:

\begin{abstract}
El Poder Judicial debería tener la oportunidad de protestar contra las invasiones proyectadas sobre el pueblo, así como sobre ellos mismos. Se había dicho que los jueces, como expositores de las Leyes, tendrían la oportunidad de defender sus derechos constitucionales. Había peso en esta observación; pero este poder de los Jueces no iba lo suficientemente lejos. Las leyes pueden ser injustas, pueden ser imprudentes, pueden ser peligrosas, pueden ser destructivas; y, sin embargo, pueden no ser tan inconstitucionales como para justificar a los Jueces a negarse a darles efecto. Permítaseles participar en el poder de Revisión, y tendrán la oportunidad de tomar nota de estas características de una ley y de contrarrestar, por el peso de sus opiniones, las posturas inadecuadas de la Legislatura. (Farrand, 1937, tomo II, p. 21)
\end{abstract}

A pesar de las objeciones recibidas, en especial en cuanto a lo inconveniente que era inmiscuir a los jueces en cuestiones de índole política, un mes después, el 23 de agosto de 1787, Wilson volvió a referirse al control previo y abstracto de los jueces en el marco de la propuesta del Consejo de Revisión:

La firmeza de los Jueces no es en sí misma suficiente. Algo más es indispensable. Sería mejor prevenir la sanción de una ley indebida, que declararla nula después de sancionada. (Farrand, 1937, tomo II, p. 391)

Debido al temor hacia los eventuales abusos del Poder Legislativo, Wilson prefería un sistema de control adicional al deber que ya tenían los jueces de declarar la invalidez de una ley que contradijera la Constitución en el marco de un caso concreto. Sin embargo, una vez sancionada la Constitución, defendió ese deber de los jueces como un mecanismo de control de las leyes. De hecho, en la Convención de ratificación de Pensilvania, que tuvo lugar entre los meses de noviembre y diciembre de 1787 , Wilson resaltó tanto la importancia de la independencia de los jueces como la del deber que tenían de declarar la invalidez de las leyes inconstitucionales. Lo hizo para responder a aquellos que criticaban ese control judicial por considerarlo una herramienta que no iba a prevenir los posibles abusos del Congreso:

bajo esta Constitución, la legislatura puede ser restringida, y mantenida dentro de los límites que se le fijaron, a través de la intervención del departamento judicial. [...] Tuve ocasión, en un día anterior, de declarar que el poder de la 
Constitución era superior al poder de la legislatura que actuaba bajo esa Constitución; dado que es posible que la legislatura, actuando en esa capacidad, pueda transgredir los límites asignados a ella, y una ley pueda sancionarse, en el modo habitual, a pesar de esa transgresión; pero cuando esa ley llegue a ser discutida ante los jueces, cuando consideren sus principios y encuentren que son incompatibles con el poder superior de la Constitución, su deber es declararla nula; y los jueces, independientes y no obligados a buscar en cada sesión el mantenimiento de sus salarios, se comportarán con intrepidez y rechazarán darle a esa ley la sanción de la autoridad judicial. (Elliot, 1836, tomo II, pp. 445-446)

Frente a tan claro planteo, un convencional argumentó que los jueces que declararan inconstitucional una ley del Congreso en el marco de un juicio podrían ser removidos a través del impeachment. El planteo parecía estar fundado en un reciente intento, si bien infructuoso, de la Legislatura de Rhode Island después de que la Corte Superior estatal invalidara una ley en 1786 en el caso Trevett $v$. Weeden. ${ }^{29}$ La respuesta de Wilson fue contundente:

La última observación concierne a los jueces. Se dice que, si llegan a decidir en contra de la ley, una cámara los acusará y la otra los condenará. Espero que los caballeros muestren cómo puede suceder esto; porque una mera suposición no debe admitirse como prueba. Los jueces deben ser enjuiciados, porque deciden que una ley es nula y sin efecto, ipor haber sido sancionada desafiando a la Constitución! ¿Qué Cámara de Representantes se atrevería a enjuiciar, o qué Senado a juzgar, a jueces por el cumplimiento de su deber? (Elliot, 1836, tomo II, p. 478)

En respuesta a un planteo de otro convencional que sostuvo que así y todo podían sancionarse leyes inconsistentes con la Constitución, Wilson insistió en destacar el carácter superior de esta, los límites del Congreso y el rol de los jueces:

29 Para un detalle completo de los pormenores del caso, ver Warren (1923, Vol.. 32, pp. 16-22). El abogado de la defensa en ese caso fue James Mitchell Varnum, un célebre general del ejército de Washington que había estudiado en Harvard y en Brown. Varnum defendió a un carnicero que se había negado a recibir papel moneda debido a la inflación y corría el riesgo de ir a la cárcel por negarse a cumplir una ley estatal. A pedido de la población de Rhode Island, los argumentos de Varnum fueron publicados al año siguiente de decidido el caso. Como parte de su defensa, Varnum sostuvo: "Have the Judges a power to repeal, to amend, or to alter laws? -God forbid!- In that case they would become Legislators.- Have the Legislators power to direct the Judges how they shall determine upon the laws already made? -God forbid!- In that case they would become Judges.- The true distinction lies in this, that the Legislative have the incontroulable power of making laws not repugnant to the constitution.- The Judiciary have the sole power of judging of those laws, and are bound to execute them; but cannot admit any act of the Legislative as law, which is against the constitution" (Varnum, 1787, p. 27). 
Si una ley fuera incompatible con los poderes conferidos al Congreso por este instrumento, los jueces, como consecuencia de su independencia y de que los poderes particulares del gobierno son definidos, declararán que esa ley es nula; porque predomina el poder de la Constitución. Por lo tanto, cualquier cosa que sea promulgada por el Congreso en contra de la misma, no tendrá fuerza de ley. (Elliot, 1836, tomo II, p. 489)

En sus famosas Lectures on Law, cuya primera exposición fue el 15 de diciembre de 1790 con la presencia del propio Washington, su vicepresidente, John Adams, y todos los miembros del Congreso, el entonces Justice Wilson explicaba:

El departamento legislativo, así como cualquier otra parte del gobierno, deriva su poder de la constitución: el legislativo, así como cualquier otro departamento, debe ser dirigido por la constitución; ninguna modificación de la constitución por parte de la legislatura puede ser hecha o autorizada. En nuestro sistema jurídico, estas posiciones parecen ser incontrovertibles. La constitución es la ley suprema del país: cualquier otro poder debe ser inferior y subordinado a esa ley suprema. Ahora, supongamos, que la legislatura apruebe una ley, manifiestamente repugnante con alguna parte de la constitución; y que el funcionamiento y la validez de ambas lleguen a cuestionarse regularmente ante un tribunal, que forma parte del departamento judicial. En ese departamento es que el "pueblo" otorgó el "poder judicial de los Estados Unidos", al "ordenar y establecer" la constitución. El diseño y la función del poder judicial es administrar justicia de acuerdo con la ley del país. La justicia, conforme a la naturaleza de las cosas, no puede administrarse bajo dos reglas contradictorias. Una de ellas debe, necesariamente, ceder a la otra. (Hall y Hall, 2007, p. 742) ${ }^{30}$

Acto seguido, Wilson destacaba el deber que tenían los jueces de anular las leyes que contradijeran la Constitución:

Ambas, de acuerdo con nuestra suposición, aparecen de forma regular ante un tribunal, para su decisión acerca de su funcionamiento y validez. Es el derecho y es el deber del tribunal decidir sobre ellas: su decisión debe tomarse, porque la justicia debe administrarse de acuerdo con la ley del país. Cuando surge la pregunta: ¿Cuál es la ley del país? También debe decidirse esta cuestión. ¿De qué manera es que debe decidirse esta cuestión? La respuesta parece ser muy fácil. El poder supremo de los Estados Unidos ha dado una regla: un poder subordinado

30 Wilson dio esas lecciones entre 1790 y 1792 en el entonces College of Philadelphia (hoy, la University of Pennsylvania). Las Lectures on Law fueron publicadas en 1804, seis años después de la muerte de Wilson, por impulso de su hijo Bird Wilson (Hall, 2004, p. 63). 
en los Estados Unidos ha dado una regla contradictoria: la primera es la ley del país: como consecuencia necesaria, la segunda es nula y no tiene ninguna operación. Conforme la constitución de los Estados Unidos, es el derecho y el deber de un tribunal de justicia decidir de esta forma. Este es el resultado necesario de la distribución del poder, que hizo la constitución, entre los departamentos legislativo y judicial. La misma constitución es la ley suprema para ambos. Si esa constitución es infringida por uno, no es razón para que la infracción deba ser incitada, sino que es una razón fuerte para que el otro deba desconocerla y declararla nula. Los efectos de esta saludable regulación, que resultan necesariamente de la constitución, son grandes e ilustres. Como consecuencia de ello, los límites del poder legislativo, un poder que es de lo más apto para traspasar sus límites, no solo están claramente marcados en el sistema mismo; sino que se hace una provisión efectiva y permanente para que toda transgresión de esos límites se juzgue y se haga vana e infructuosa. ¡Qué noble salvaguardia contra el despotismo legislativo! (Hall y Hall, 2007, tomo I, pp. 742-743)

Esta visión acerca del carácter de norma jurídica fundamental de la Constitución, de los límites que impone al Poder Legislativo y del deber de los jueces de anular las leyes que la contradigan no implica sostener que Wilson tenía una visión activista del Poder Judicial. Por el contrario, remarcaba que los jueces deben recordar que "su deber y su trabajo no es hacer la ley, sino interpretarla y aplicarla” (Hall y Hall, 2007, tomo II, p. 953).

Wilson había sido designado por Washington como Justice de la Suprema Corte el 8 de febrero de 1790 y ejercería ese cargo hasta su muerte, el 21 de agosto de $1798 .{ }^{31}$ Como explicaré más adelante, como juez de la Corte de Circuito de Pensilvania tuvo un rol destacado en el caso Hayburn. Ese caso, decidido el 11 de abril de 1792 bajo el liderazgo de Wilson, ${ }^{32}$ marcó un hito histórico: fue la primera vez en la que un tribunal federal declaró la inconstitucionalidad de una ley del Congreso en los Estados Unidos.

\subsubsection{Alexander Hamilton}

Nacido en la isla de Nieves, en las Antillas, el 11 enero de 1755, quedó huérfano a los 13 años y tuvo que educarse con un tutor. Después de lograr pagarse

31 Wilson fue el primer Justice que murió en funciones. Sobre la carrera de Wilson en la Suprema Corte y los problemas que tuvo en los últimos años de su vida como consecuencia de sus deudas, que lo llevaron a ser encarcelado y a huir de sus acreedores, ver Marcus (2019, p. 147). Este triste e indecoroso final para una figura tan importante es lo que tal vez explique (pero no justifique) lo poco estudiado que es Wilson en general.

32 Cfr. (Hall, 1998, p. 137). 
un viaje de estudios mediante una colecta popular, pudo radicarse en los Estados Unidos y estudiar economía y leyes en la actual Universidad de Columbia, en Nueva York. A partir de allí, tendría una carrera pública meteórica que quedaría trunca a los 49 años, luego de un duelo con Aaron Burr. ${ }^{33}$

Son bien conocidas las referencias de Hamilton acerca del control de constitucionalidad en El Federalista $\mathrm{N}^{\circ} 78$, publicado el 28 de mayo de 1788. Allí, entre otros argumentos, sostuvo:

El derecho de los tribunales a declarar nulas las leyes de la legislatura, por ser contrarias a la Constitución, ha suscitado ciertas perplejidades debido a la creencia de que esa doctrina implicaría la superioridad del poder judicial frente al legislativo. Se arguye que la autoridad que puede declarar nulos los actos de otra, necesariamente será superior a aquella cuyos actos pueden ser anulados. Dado que esta doctrina es de gran importancia para todas las constituciones Americanas, no estará de más discutir brevemente los fundamentos en que descansa. No hay proposición que se apoye sobre principios más claros que la que afirma que es nulo todo acto de una autoridad delegada, que sea contrario a los términos del mandato bajo el cual se ejerce. Por lo tanto, ningún acto legislativo contrario a la Constitución puede ser válido. Negar esto equivaldría a afirmar que el mandatario es superior al mandante, que el servidor está por encima de su amo, que los representantes del pueblo son superiores al pueblo mismo, y que los hombres que obran en virtud de ciertos poderes pueden hacer no sólo lo que estos no permiten, sino incluso lo que ellos prohíben. (Hamilton, Madison y Jay, 1818, p. 485)

\section{Y, a renglón seguido, Hamilton agregó:}

Si se dijera que el cuerpo legislativo es, por sí solo, el juez constitucional de sus propios poderes y que la interpretación que hiciera de ellos es decisiva para los otros departamentos, se puede responder que no puede ser ésta la presunción natural cuando esto no se derive de alguna disposición en particular de la Constitución. No es admisible suponer que la Constitución haya podido tener la intención de facultar a los representantes del pueblo para sustituir su VOLUNTAD a la de sus electores. Es mucho más racional suponer que los tribunales han sido concebidos como un cuerpo intermedio entre el pueblo y la legislatura, a fin de, entre otras cosas, mantener a esta última dentro de los límites asignados a su autoridad. La interpretación de las leyes es propia y peculiarmente una atribución de los tribunales. Una Constitución es de hecho una ley fundamental y así debe ser considerada por los jueces. Por lo tanto, a ellos les corresponde determinar su significado, así

33 Entre las numerosas biografías sobre Hamilton que se han publicado, recomiendo la de Ron Chernow (2004). 
como el de cualquier ley en particular que provenga del cuerpo legislativo. Y si ocurriere que entre las dos hay una discrepancia, debe preferirse, como es natural, aquella que posee fuerza obligatoria y validez superiores; en otras palabras, la Constitución debe preferirse a la ley ordinaria, la intención del pueblo a la intención de sus agentes. Esta conclusión no implica de ningún modo la superioridad del poder judicial sobre el legislativo. Sólo implica que el poder del pueblo es superior a ambos y que donde la voluntad de la legislatura, declarada en sus leyes, se halla en oposición con la del pueblo, declarada en la Constitución, los jueces deberán gobernarse por esta última, en lugar de las primeras. Deberán regular sus decisiones por las leyes fundamentales, en lugar de aquellas que no lo son. (Hamilton, Madison y Jay, 1818, pp. 485-486)

No tan conocidas son las referencias del mismo Hamilton en El Federalista $\mathrm{N}^{\circ} 16$, en el que, luego de plantear la posibilidad de distinguir entre el ejercicio legal de un poder y la ilegal usurpación de una autoridad, planteó que:

El éxito de esa usurpación requeriría no solo una mayoría facciosa en la legislatura, sino también la connivencia de los tribunales de justicia y de la masa del pueblo. Si los jueces no se embarcaran en una conspiración con la legislatura, declararían que las resoluciones de esa mayoría son contrarias a la ley suprema del país, inconstitucionales y nulas. (Hamilton, Madison y Jay, 1818, p. 101)

Todas estas reflexiones de Hamilton fueron anticipadas en el marco de un conocido caso en Nueva York en 1784. Junto con otros abogados, representó a Joshua Waddington, un agente de dos mercaderes británicos a quienes Elizabeth Rutgers, viuda y patriota, les reclamaba el pago de alquileres por la ocupación de una propiedad que le había sido confiscada por autoridades realistas. Cabe recordar que Nueva York estuvo bajo el control de las fuerzas británicas desde 1776 hasta la firma del Tratado de Paz en 1783. Varios patriotas huyeron del estado luego de la ocupación militar británica y tuvieron que abandonar sus propiedades. En el caso de Rutgers, su negocio fue primero saqueado y luego restaurado y explotado por los mercaderes británicos representados por Waddington, quienes habían obtenido el permiso correspondiente de las autoridades civiles y militares británicas. En Rutgers v. Waddington, ${ }^{34}$ Hamilton planteó como defensa la inconstitucionalidad de una ley estatal, la Trespass Act de 1783, que reconocía a los patriotas una acción judicial para reclamar por la ocupación de propiedad que había quedado sujeta al control del Gobierno de Gran Bretaña durante la guerra de independencia. Hamilton argumentó, entre

34 Ver Arguments and Judgment of the Major's Court of the City of New York, in a cause between Elizabeth Rutgers 
otras cosas, que la Trespass Act violaba el Tratado de Paz con Inglaterra, una norma federal de rango superior que había otorgado una suerte de amnistía que incluía las acciones del Gobierno británico que habían favorecido a su cliente. ${ }^{35}$ Cabe recordar que, a ese momento, aún no se había sancionado la Constitución de 1787 y el país se regía por las Artículos de Confederación de 1781. El planteo de Hamilton en favor de su impopular cliente fue receptado parcialmente por el tribunal en un fallo que causó gran impacto en la época (Chernow, 2004, p. 199).

\subsubsection{James Madison}

Tenía solamente 36 años cuando fue designado como uno de los delegados por el estado de Virginia en la Convención de Filadelfia en 1787. Tan importante fue su trabajo que algunos autores lo señalan como el "padre de la Constitución de los Estados Unidos”. ${ }^{36}$ A pesar de no haber escrito con la precisión de Iredell, Wilson o Hamilton acerca del control judicial de constitucionalidad (recordemos que Madison no era abogado), ${ }^{37}$ existen varias referencias en documentos públicos y privados que demuestran que lo consideraba como uno de los frenos y contrapesos de su sistema de separación de poderes. ${ }^{38} \mathrm{Y}$, fundamentalmente, como una forma proteger los derechos finalmente incluidos en el Bill of Rights. ${ }^{39}$

El punto de partida del pensamiento tanto de Madison como de la mayoría de los convencionales constituyentes está marcado, entre otras cosas, por una profunda desconfianza hacia el Poder Legislativo. Madison dejó expresada en más de una oportunidad esa desconfianza que los constituyentes norteamericanos tenían no solo respecto al poder del legislador, sino también de las faccio-

and Joshua Waddington, impreso por Samuel Loudon, Nueva York, 1784, pp. 3-47.

35 Para un análisis minucioso de los argumentos desplegados por Hamilton, ver Treanor (2005, pp. 480-487).

36 Cfr. Ketcham (1990, p. 229).

37 Al respecto, ver Corwin (1939, p. 821).

38 Tal como explica Gargarella (2008), Madison fue "el principal ideólogo del sistema de 'frenos y contrapesos", al que consideraba como "el único remedio institucional adecuado frente al egoísmo y la ambición de poder que parecía inherente a la naturaleza del hombre” (p. 16). Para un análisis detallado del pensamiento constitucional de Madison y su influencia en nuestro país, ver García-Mansilla y Ramírez Calvo (2003, p. 139).

39 Al respecto, ver Patterson (1939, p. 22). 
nes que operan a través del Gobierno. ${ }^{40}$ En la sesión del 21 de julio de 1787 en la Convención de Filadelfia, Madison advirtió que:

La experiencia en todos los Estados ha evidenciado una poderosa tendencia en la Legislatura de absorber todo el poder en su vórtice. Esta fue la verdadera fuente de peligro para las Constituciones Americanas; y sugirió la necesidad de dar toda autoridad defensiva a los otros departamentos que fuera consistente con los principios republicanos. (Farrand, 1937, tomo II, p. 74)

La propuesta de Madison en la Convención, apoyada por Wilson, fue la de incluir un Consejo de Revisión con participación de los jueces para hacer un control anterior a la ejecución de las leyes federales. Esa moción no fue aceptada, a pesar de las cuatro veces que Madison y sus aliados intentaron aprobarla. Lo llamativo del caso es que muchos de los convencionales que se oponían a la participación del Poder Judicial en el Consejo era porque consideraban que los jueces ya ejercerían un rol similar, pero a través del control judicial de constitucionalidad en el marco de un caso concreto. Así, por ejemplo, se manifestaron los siguientes convencionales:

- Elbridge Thomas Gerryః según consta en las notas sobre la Convención, Gerry, futuro vicepresidente de Madison y firmante de la Declaración de Independencia en 1776, expresó sus dudas de esta forma:

El Sr. Gerry duda si el Poder Judicial debe formar parte de él, ya que los jueces tendrán un control suficiente contra invasiones en su propio departamento a través de su interpretación de las leyes, que incluía un poder de decidir sobre su Constitucionalidad. (Farrand, 1937, tomo I, p. 97)

- Rufus King: al igual que Gerry, se opuso al Consejo de Revisión debido a que los jueces ya tenían el deber de controlar la constitucionalidad de las leyes que fueran cuestionadas en el marco de los casos que tuvieran que decidir:

El Sr. King opinó que el Poder Judicial no debería unirse al veto de una Ley, porque los Jueces tendrán la interpretación de esas Leyes cuando se presenten ante ellos; y sin duda detendrán la operación de aquellas que parezcan repugnantes a la constitución. (Farrand, 1937, tomo I, p. 109)

- Luther Martin: eximio abogado que lideraría posteriormente la oposición

40 Para ver la evolución del pensamiento de Madison al respecto, ver Rakove (1992, p. 667). 
antifederalista y representaría años después a Samuel Chase en su proceso de remoción y a Aaron Burr en el proceso que se le siguió por traición en 1807. Rechazó la participación de los jueces en el Consejo de esta forma:

El Sr. L. Martin consideraba la asociación de los Jueces con el Ejecutivo como una innovación peligrosa; así como una que no podría producir la ventaja particular que se espera de ella. No se puede suponer que el conocimiento de la humanidad y de los asuntos legislativos pertenezca en mayor grado a los Jueces que a la legislatura. Y en cuanto a la Constitucionalidad de las leyes, ese punto se presentará ante los jueces en su propio carácter oficial. En ese carácter tienen un poder negativo sobre las leyes. Si se los une con el Ejecutivo en un Consejo de Revisión tendrían un doble control negativo. (Farrand, 1937, tomo II, p. 76)

- George Mason: en respuesta a Martin, el principal redactor de la Declaración de Derechos de Virginia de 1776, al apoyar la propuesta de Madison de creación del Consejo de Revisión, expresó:

Se había dicho [por el Sr. L. Martin] que si los jueces se unieran a este control de las leyes, tendrían un doble control negativo, ya que en su capacidad expositiva como jueces ya tendrían uno. Él respondería que en esta capacidad podrían impedir en un solo caso, el funcionamiento de las leyes. Podrían declarar nula una ley inconstitucional. Pero con respecto a todas las leyes, por injustas, opresivas o perniciosas que sean, que no quedaran claramente incluidas en esta descripción, estarían como Jueces bajo la necesidad de darles vía libre. Él deseaba un mayor uso de la ayuda que podían dar los jueces para prevenir toda ley impropia. (Farrand, 1937, tomo II, p. 78)

Mason expresaba así la distinción que había entre el control judicial de constitucionalidad ya existente, con sus efectos limitados al caso concreto decidido por los jueces, y la propuesta del Consejo de Revisión que no venía a reemplazarlo, sino que implicaba un control previo y más ambicioso por su mayor alcance.

Así como Madison buscaba la forma de limitar el poder del legislador, otros convencionales compartían esa preocupación y la relacionaban con el control judicial de constitucionalidad. Gouverneur Morris, por ejemplo, al momento de discutir el mecanismo de ratificación de la Constitución a través de las legislaturas estatales o a través de convenciones electas por el pueblo, sostuvo:

Las modificaciones legislativas que no se ajusten al pacto federal, serían claramente inválidas. Los Jueces las considerarían nulas y sin efecto. (Farrand, 1937, tomo II, p. 92) 
En idéntico sentido se expresó Madison:

El Sr. MADISON pensaba que era claro que las legislaturas eran incompetentes para los cambios propuestos. Estos cambios harían incursiones esenciales en las Constituciones estatales, y sería una doctrina nueva y peligrosa que una Legislatura pudiera cambiar la constitución a la cual debía su existencia. De hecho, podría haber algunas Constituciones dentro de la Unión, que le habían otorgado un poder a la Legislatura para participar en las modificaciones al Pacto federal. Pero ciertamente había algunas que no; y en el caso de éstas, necesariamente se debe obtener una ratificación por parte del pueblo. Él consideraba que la diferencia entre un sistema fundado solo en las Legislaturas y uno fundado en el pueblo, como la verdadera diferencia entre una liga o tratado y una Constitución. La primera en cuanto a la obligación moral podría ser tan inviolable como la segunda. En cuanto a la operación política, había dos distinciones importantes a favor de esta última. Una ley que viole un tratado ratificado por una ley preexistente, podría ser respetada por los Jueces como una ley, aunque una imprudente o pérfida. Una ley que viole una constitución establecida por el propio pueblo sería considerada por los jueces como nula y sin efecto. (Farrand, 1937, tomo II, pp. 92-93)

Si bien podría argumentarse que aquí se refiere solamente a la mejor forma de ratificación de la Constitución de 1787, lo cierto es que Madison distingue a la Constitución de un tratado y dice claramente que una ley que viole la ley fundamental establecida por el pueblo puede ser invalidada por los jueces.

Sancionada la Constitución, esa desconfianza tanto hacia el Poder Legislativo como a las facciones mayoritarias que operan a través del Gobierno no cejaron en el pensamiento de Madison:

[A]lli donde quiera que resida el poder real del Gobierno, existe el riesgo de opresión. En nuestros Gobiernos el poder real reside en la mayoría de la Comunidad, y la invasión de los derechos privados es de esperarse que proceda, principalmente, no de actos de Gobierno contrarios al sentir de sus ciudadanos, sino de actos en los que el Gobierno es un mero instrumento del mayor número de ellos. ${ }^{41}$

En ese marco, Madison también defendió el control judicial de constitucionalidad como forma de preservar los derechos naturales reconocidos en el Bill of Rights. Hay que recordar que a pesar de que la Convención de Filadelfia había ideado la constitución como medio para estructurar y limitar al Gobierno

41 Ver carta de Madison a Thomas Jefferson del 17 de octubre de 1788 en Madison (1999, p. 420). 
y, a través de esa regulación, garantizar la protección de los derechos naturales de las personas, había omitido una declaración de derechos. ${ }^{42}$ Esa omisión generó las críticas y la oposición de los antifederalistas a la Constitución de 1787 durante el proceso de ratificación en los diferentes estados de la Unión. ${ }^{43} \mathrm{La}$ falta de un Bill of Rights tuvo que ser explicada, entonces, en las convenciones estaduales en las que se discutía si se ratificaba o no la Constitución de Filadelfia. En Carolina del Sur, por ejemplo, Charles Pickney justificaba la ausencia de una declaración de derechos y explicaba que "como tal vez podríamos haber omitido la enumeración de algunos de nuestros derechos, entonces podría decirse que habíamos delegado en el gobierno general el poder de sacarnos aquellos de nuestros derechos que no hubiésemos enumerado" (Elliot, 1836, tomo IV, p. 316). De forma similar, durante la Convención de Ratificación en Pensilvania, James Wilson explicaba que "si intentamos una enumeración, todo lo que no esté enumerado se presumirá como entregado. La consecuencia es que, una imperfecta enumeración arrojará todos los poderes implícitos en manos del gobierno, y así los derechos de las personas quedarán incompletos" (Elliot, 1836, tomo II, p. 436). El trasfondo del problema es la visión expansiva que los constituyentes norteamericanos tenían respecto a los derechos naturales o "libertades" de las personas que el Gobierno debía asegurar y proteger. Eso hacía prácticamente imposible su enumeración. ${ }^{44}$

La solución al problema planteado por esa visión expansiva y la consiguiente imposibilidad de enumerar todos los derechos naturales fue ideada por Madison. Pese a que originalmente era escéptico acerca de la necesidad de incluir un catálogo de derechos, Madison finalmente lideró la propuesta de adopción del Bill of Rights. ${ }^{45}$ Para ello, propuso una reforma que permitía proteger la con-

42 Sobre la idea de los derechos naturales, ver García-Mansilla (2014, pp. 511-560).

43 Cfr. Levy (1999, pp. 25 y ss.).

44 Vale la pena recordar la opinión que Iredell, futuro Justice de la Suprema Corte, durante la Convención de Carolina del Norte. Luego de rechazar las críticas por la falta de una declaración de derechos, Iredell sostuvo la imposibilidad de enumerarlos y la consiguiente peligrosidad de incluir una lista incompleta. Y remató su exposición del siguiente modo: "It would not only be useless, but dangerous, to enumerate a number of rights which are not intended to be given up; because it would be implying, in the strongest manner, that every right not included in the exception might be impaired by the government without usurpation; and it would be impossible to enumerate every one. Let any one make what collection or enumeration of rights he pleases, I will immediately mention twenty or thirty more rights not contained in it" (Elliot, 1836, tomo IV, p. 167).

45 Jefferson es quien terminaría de convencer a Madison acerca de la necesidad de incluir el Bill of Rights, en una carta enviada el 15 de marzo de 1789 en la que resalta la importancia del control judicial sobre las leyes: "In the arguments in favor of a declaration of rights, you omit one which has great weight with me, the legal check which it puts into the hands of the judiciary. This is a body, 
cepción amplia de los derechos naturales y evitar el peligro de la enumeración. Su propuesta sería finalmente reflejada en la Enmienda IX de la Constitución estadounidense: "La enumeración de ciertos derechos en la Constitución no será interpretada para denegar o menoscabar otros retenidos por el pueblo”.

Madison defendió la inclusión del Bill of Rights en un discurso pronunciado en la Cámara de Representantes el 8 de junio de 1789. Allí dijo:

Creo que la mayoría de las personas que se opusieron a ella [la Constitución], lo hicieron porque no contenía disposiciones efectivas contra las violaciones de los derechos individuales ni aquellas salvaguardias que hace tiempo se acostumbran a interponer entre ellos y el magistrado que ejerce el poder soberano. (Madison, 1999, p. 441)

Madison consideraba a la declaración de derechos como un límite al poder del Gobierno y una protección de esos derechos frente a los posibles abusos de este. Más adelante, en el mismo discurso, compara la declaración de derechos británica con la que se proponía para los Estados Unidos. Allí, deja claro que la Constitución tiene el carácter de norma jurídica directamente invocable por los particulares para resistir los eventuales abusos del Gobierno:

En la declaración de derechos establecida por ese país [Gran Bretaña], la verdad
es que no han hecho más que establecer una barrera contra el poder de la co-
rona, pero el poder de la legislatura permanece ilimitado. [...] Aunque el caso
pueda ser totalmente diferente y no se haya considerado necesario establecer
límites al poder legislativo en ese país, una opinión diferente prevalece en los Es-
tados Unidos. El pueblo de los diferentes Estados ha creído necesario establecer
barreras contra el poder en todas las formas y departamentos de gobierno [...].
(Madison, 1999, p. 445)

Finalmente, luego de insistir en la importancia del Bill of Rights para prevenir y resistir los posibles excesos cometidos por el Gobierno o la comunidad, Madison sostuvo que la incorporación de los derechos naturales a la Constitución iba a tener un efecto saludable. La protección contra esos abusos de poder estaría en mano de los jueces. En palabras de Madison:

Tribunales de justicia independientes se considerarán a sí mismos de forma peculiar como los guardianes de esos derechos; se convertirán en un baluarte

which if rendered independent, and kept strictly to their own department merits great confidence for their learning and integrity" (Koche y Peden, 2004, p. 426). 
inexpugnable frente a cualquier asunción de poder por parte del legislativo o el ejecutivo; serán llevados naturalmente a resistir cualquier violación de los derechos expresamente contemplados en la Constitución a través de la declaración de derechos. (Madison, 1999, p. 449)

Queda claro, entonces, que Madison pretendía que la declaración de derechos pudiera ser invocada por los ciudadanos ante los poderes públicos y muy especialmente en juicio. Bajo esa concepción, central para el constitucionalismo estadounidense, el propósito principal del control judicial de constitucionalidad es la protección de los derechos llamados "naturales". Esos derechos no son considerados como otorgados por el Gobierno o la mayoría, sino que son reconocidos como preexistentes en la Constitución y operan como un límite al Gobierno y a la mayoría. Y los jueces son los encargados de proteger esos derechos contra las decisiones que eventualmente los infrinjan, especialmente en el caso del Congreso, pero también del Poder Ejecutivo. ${ }^{46}$

\subsubsection{Oliver Ellsworth}

Fue miembro de la Convención de Filadelfia por el estado de Connecticut. Tuvo después una activa participación durante el proceso de ratificación en su estado natal, tanto a través de la publicación de trece ensayos anónimos conocidos como "Letters of a Landholder" 47 (que en la época llegó a ser comparado con El Federalista), como en la propia Convención estatal reunida en Hartford en $1788 .{ }^{48}$ Después de ser elegido senador, ayudó en el diseño y sanción de la Judiciary Act de $1789 .{ }^{49}$ Posteriormente, fue designado por Washington en el cargo de Chief Justice en reemplazo de John Rutledge, a quien el Senado le había negado el acuerdo después de haber sido designado en comisión en remplazo de John Jay. Se mantuvo en ese cargo desde el 8 de marzo de 1796 hasta su retiro, el 15 de diciembre de 1800.

En un influyente discurso pronunciado el 7 de enero de 1788 en la Convención de Ratificación del estado de Connecticut, Ellsworth sostuvo:

Esta Constitución define el alcance de los poderes del gobierno general. Si la

\footnotetext{
46 Cfr. Gerber (2011, p. 342).

47 Ver Sheehan y McDowell (1998, pp. 286 y ss.).

48 Cfr. Casto (1996, p. 77).

49 Al respecto, ver Ritz (1990).
} 
legislatura general sobrepasa en algún momento sus límites, el departamento judicial es un control constitucional. Si los Estados Unidos van más allá de sus poderes, si sancionan una ley que la Constitución no autoriza, es nula; y el poder judicial, los jueces nacionales, que para garantizar su imparcialidad serán independientes, la declararán nula. Por otro lado, si los estados van más allá de sus límites, si hacen una ley que es una usurpación sobre el gobierno general, la ley es nula; y los jueces honorables e independientes declararán que es así. (Elliot, 1836, tomo II, p. 196)

Los argumentos del ex convencional y futuro Chief Justice son similares a los expuestos por Iredell, Wilson, Hamilton, Madison y los demás convencionales y jueces que expresaron su confianza en el deber de los jueces de decidir los casos aplicando la constitución como ley suprema y fundamental y de ejercer el control constitucional para invalidar las leyes del Congreso que no la respetasen.

\subsubsection{John Blair}

Fue miembro de la Convención de Filadelfia por el estado de Virginia. Posteriormente, fue designado por el presidente Washington como Justice de la Suprema Corte, cargo que ocupó desde el 2 de febrero de 1790 hasta su renuncia, el 25 de octubre de 1795 (Holt, 1998, pp. 155 y ss.). Blair había integrado previamente la Corte de Apelaciones de Virginia, que decidió en 1782 el conocido caso Commonwealth v. Caton. ${ }^{50}$ En el llamado "Caso de los Prisioneros", 51 los jueces del tribunal invitaron a que los abogados que tuvieran interés dieran su opinión. St. George Tucker, uno de los juristas más importantes de la época, se presentó e hizo una elaborada defensa del control judicial de constitucionalidad de las leyes, tal vez la más antigua del período revolucionario anterior a la sanción de la Constitución de Filadelfia. ${ }^{52}$

A la hora de resolver el caso, veintiún años antes que Marbury v. Madison, uno de los colegas de Blair explicó que:

si toda la legislatura, un evento que debe ser desaprobado, intentara sobrepasar los límites prescritos por el pueblo, Yo, al administrar la justicia pública del país, asumiré los poderes unidos en mi sede en este tribunal; y, señalando a la cons-

\footnotetext{
508 Va. (4 Call.) 5 (1782).

51 Para ver los pormenores de este caso y su importancia como antecedente de la judicial review es de consulta obligada el exhaustivo trabajo de Treanor (1994, p. 491).

52 Ver Treanor (1994, pp. 522-529).
} 
titución, les diré a ellos, aquí está el límite de su autoridad; y hasta aquí podrán ir, pero no más allá. ${ }^{53}$

En cuanto a la actuación de Blair, al final del reporte del caso se advierte que:

El Chancellor Blair y el resto de los jueces eran de la opinión que el tribunal tenía el poder de declarar cualquier resolución o ley de la legislatura, o de cualquiera de sus ramas, como inconstitucional y sin efecto. ${ }^{54}$

Si bien la personalidad de Blair era más bien apocada, participó también junto con James Wilson de la decisión de la Corte de Circuito de Pensilvania que declaró inconstitucional por primera vez una ley del Congreso en 1792 (Holt, 1998, p. 168), caso sobre el que me referiré más adelante.

\subsubsection{William Paterson}

Oriundo de Irlanda, emigró a los Estados Unidos a muy temprana edad junto con sus padres. Fue miembro de la Convención de Filadelfia por el estado de Nueva Jersey, en el que había sido Attorney General, entre 1776 y 1783, y gobernador, entre 1790 y 1793 . Luego de finalizada la Convención, fue elegido senador y allí colaboró con Oliver Ellsworth en la sanción de la Judiciary Act de $1789.5^{55}$ Después de renunciar a su cargo de gobernador, ocupó el de Justice luego de ser designado por el presidente Washington. Se mantuvo en ese cargo desde el 4 de marzo de 1793 hasta su muerte, el 9 de septiembre de 1806.

El Justice Paterson dejó sentada su opinión acerca del deber de los jueces de controlar la constitucionalidad de las leyes en una exposición que hizo en 1795 ante el Grand Jury en el caso Vanhorne's Lessee v. Dorrance, ${ }^{56}$ una decisión de la corte de circuito de Pensilvania. Cabe recordar que era una práctica aceptada desde los tiempos de la Revolución que los jueces de la Suprema Corte, en su trabajo en las cortes de circuito, hicieran este tipo de exposiciones, en algunos casos con contenido de índole político. ${ }^{57}$ En esa oportunidad, después de destacar las diferencias entre la Constitución inglesa y la de los Estados Unidos, Paterson explicó:

538 Va. (4 Call.), p. 8 (voto del Chancellor George Whyte, quien había sido profesor de Derecho de John Marshall en el College of William and Mary Treanor (Treanor, 1994, p. 497)).

548 Va. (4 Call.), p. 20.

55 Ver Degnan (1998, pp. 238-240).

56 2 U.S. (2 Dall.) 304 (1795).

57 Sobre el punto, ver Lerner (1967, p. 127). 
¿Qué es una constitución? Es la forma de gobierno, delineada por la poderosa mano del pueblo, en la cual se establecen ciertos primeros principios de leyes fundamentales. La Constitución es cierta y fija; contiene la voluntad permanente del pueblo y es la ley suprema del país; es superior al poder de la Legislatura, y solo puede ser revocada o alterada por la autoridad que la hizo. El principio que le da vida y el golpe que le causa la muerte deben provenir de la misma mano. ¿Qué son las legislaturas? Criaturas de la Constitución; deben su existencia a la Constitución: derivan sus poderes de la Constitución: es su comisión; y, por lo tanto, todas sus leyes deben ser conformes a ella, o de lo contrario serán nulas. ${ }^{58}$

\section{A renglón seguido, Paterson aclaró que:}

La Constitución es el trabajo o la voluntad del pueblo mismo, en su capacidad original, soberana e ilimitada. La ley es el trabajo o la voluntad de la Legislatura en su capacidad derivada y subordinada. Una es el trabajo del Creador, y la otra de la Criatura. La Constitución fija límites al ejercicio de la autoridad legislativa y prescribe la órbita dentro de la cual debe moverse. En resumen, caballeros, la Constitución es el sol del sistema político, alrededor del cual deben girar todos los cuerpos legislativos, ejecutivos y judiciales. Cualquiera que sea el caso en otros países, sin embargo, en esto no puede haber ninguna duda: que cada ley de la Legislatura, repugnante a la Constitución, es absolutamente nula. ${ }^{59}$

Finalmente, Paterson destacó no solo el deber que tenían los jueces de declarar nulas las leyes que contradijeran la Constitución, sino también el estatus del Poder Judicial en el sistema de gobierno limitado creado en la Constitución de Filadelfia:

Considero como una posición clara que si un acto legislativo se opone a un principio constitucional, el primero debe ceder, y ser rechazado debido a su repugnancia. Sostengo que es una posición igualmente clara y sólida que, en tal caso, será deber del Tribunal adherirse a la Constitución, y declarar el acto legislativo nulo y sin efecto. La Constitución es la base de la autoridad legislativa; se encuentra en la base de toda ley, y es una regla y comisión bajo la cual tanto legisladores como jueces deben proceder. Es un principio importante, que nunca debe perderse de vista en la discusión de preguntas del presente tipo, que el poder judicial en este país no es una rama subordinada, sino coordinada del gobierno. ${ }^{60}$

Tal como explica Treanor (1994, p. 527), a pesar de tratarse de un caso en

\footnotetext{
582 U.S. (2 Dall.), p. 308.

59 Ídem.

602 U.S. (2 Dall.), p. 309.
} 
el que se discutía la constitucionalidad de una ley local, lo cierto es que la exposición de Paterson se convirtió en un ejemplo de la concepción fuerte del control judicial de constitucionalidad de la legislación en general. De hecho, fue impresa en forma de panfleto y circuló por todo el país. ${ }^{61}$

\subsubsection{Las convenciones estatales de ratificación}

Un repaso de las convenciones de ratificación muestra también el reconocimiento del control judicial de constitucionalidad por parte de otras figuras de renombre, tanto del bando de los federalistas como de los antifederalistas. Además de los mencionados previamente, entre muchos otros y sin pretensión de exhaustividad, cito los siguientes:

- Convención de Ratificación del estado de Massachusetts: en la Convención reunida en Boston en enero de 1788 para ratificar la Constitución de Filadelfia, Samuel Adams sostuvo:

Si alguna ley sancionada por el gobierno federal se extendiera más allá del poder otorgado por la Constitución propuesta, y fuera inconsistente con la constitución de este estado, será un error y será anulada por los tribunales de justicia. (Elliot, 1836, tomo II, p. 131)

- Convención de Ratificación del estado de Virginia: en la Convención reunida en Richmond en junio de 1788, Patrick Henry planteó:

Sí, señor, nuestros jueces [locales] se opusieron a las leyes de la legislatura. Tenemos este hito para guiarnos. Tenían fortaleza para declarar que eran el poder judicial y se opondrían a las leyes inconstitucionales. ¿Están seguros de que su poder judicial federal actuará así? ¿Está ese poder judicial tan bien construido, y tan independiente de las otras ramas, como nuestro poder judicial estatal? ¿Dónde están sus hitos en este gobierno? Seré directo para decir que no podrán encontrar ninguno en él. Tomo como el máximo elogio para este país el que las leyes de la legislatura, si son inconstitucionales, pueden ser rechazadas por el poder judicial. (Elliot, 1836, tomo III, p. 325)

El propio John Marshall afirmó en esa misma Convención que los jueces declararían inconstitucional una ley del Congreso sancionada en contradicción a la Constitución federal:

61 Cfr. Rosenberg (1969, p. 539). 
Si llegaran a sancionar una ley no autorizada por ninguno de los poderes enumerados, los jueces la considerarían como una infracción de la Constitución que deben salvaguardar. No considerarían que tal ley entrara bajo su jurisdicción. La declararían nula. (Elliot, 1836, tomo III, p. 553)

Frente a los cuestionamientos de algunos delegados que afirmaban que los jueces federales serían indulgentes con las autoridades federales, Marshall respondió:

\begin{abstract}
¿A qué órgano se acudiría para protección frente a una infracción de la Constitución, si no se le diera ese poder al poder judicial? No hay otro cuerpo que pueda permitir esa protección. Pero el honorable miembro se opone, porque dice que el poder judicial federal excluirá a los funcionarios de su gobierno del castigo merecido. El sheriff federal, dice él, irá a la casa de un hombre pobre y lo golpeará, o abusará de su familia, y el tribunal federal lo protegerá. ¿Algún caballero cree esto? ¿Es necesario que los funcionarios cometan una intrusión en la propiedad o en las personas de aquellos con quienes tienen que trabajar? ¿Se permitirán tales grandes insultos a la gente de este país? Si se hiciera una ley para autorizarlos, sería nula. (Elliot, 1836, tomo III, p. 554)
\end{abstract}

- Convención de Ratificación del estado de Carolina del Norte: en la primera Convención reunida en Hillsborough en julio de 1788, ${ }^{62}$ el convencional John Steele planteó:

El poder judicial de ese gobierno está tan bien construido como para ser un freno. No había frenos en la antigua Confederación. Su poder era, en principio y en teoría, trascendente. Si el Congreso hace leyes incompatibles con la Constitución, los jueces independientes no las convalidarán, ni la gente las obedecerá. Se producirá una resistencia universal. (Elliot, 1836, tomo IV, p. 71)

Cabe recordar que los convencionales del estado de Carolina del Norte conocían perfectamente el precedente sentado en Bayard $v$. Singleton, decidido apenas unos meses antes de reunirse la convención.

Las citas podrían multiplicarse, pero no quiero aburrir al lector. Tal como explican Prakash y Yoo (2003, p. 956), los delegados más importantes en al menos siete de las convenciones estatales de ratificación expresaron abiertamente que la Constitución autorizaba el control judicial de constitucionalidad de las leyes del Congreso. En ninguna de esas convenciones se negó que los tribuna-

62 Carolina del Norte tuvo dos convenciones de ratificación. En la primera, reunida en 1788 y dominada por los antifederalistas, la Constitución de Filadelfia no fue ratificada. Recién al año siguiente, en una segunda convención, Carolina del Norte ratificaría la Constitución. 
les pudieran impedir la ejecución de una ley inconstitucional ni se manifestó desconocimiento o falta de familiaridad con el deber de ejercer el control de constitucionalidad por parte de los jueces. ${ }^{63}$ No solo eso: varios de los discursos más importantes relacionados con el reconocimiento y la defensa del control judicial de constitucionalidad, incluyendo los de los futuros miembros de la Suprema Corte Wilson y Ellsworth, fueron publicados y discutidos en decenas de diarios a lo largo de varios estados (Prakash y Yoo, 2003, pp. 965-974).

\subsection{Los jueces no se autoasignaron la judicial review}

Un aspecto adicional y muy importante a tener en cuenta es la conciencia que todos tenían acerca de la novedad que estaban introduciendo en el mundo de las instituciones al reconocer el carácter de norma jurídica fundamental a una constitución escrita. En todas las justificaciones al control judicial de constitucionalidad se expone el deber (no el poder) de los jueces de aplicar la constitución escrita como norma jurídica superior a cualquier ley que sancione el Poder Legislativo. Y también que ese carácter jurídico superior de la constitución tiene que ver con la idea de imponer límites a todo el gobierno federal, especialmente al legislador. La constitución se convierte así en la ley que gobierna a aquellos que gobiernan. ${ }^{64}$

Esta novedad en cuanto a la constitución era constantemente remarcada en los Estados Unidos, en especial para contrastarla con el ejemplo de Gran Bretaña. Madison lo expresa muy bien en El Federalista $\mathrm{N}^{\circ}$ 53:

La importante distinción, tan bien comprendida en América, entre una Constitución establecida por el pueblo e inalterable por el gobierno y una ley establecida y alterable por el gobierno, parece haber sido mal comprendida y menos observada en cualquier otro país. Dondequiera que haya residido el supremo poder de legislar, se ha supuesto que también residía una potestad plena para cambiar la forma de gobierno. Inclusive en Gran Bretaña, donde los principios de la libertad política y civil han sido más discutidos y donde más se habla de los derechos de la Constitución, se sostiene que la autoridad del Parlamento es suprema e incontrolable, tanto con respecto a la Constitución, como a los objetos ordinarios sobre los que dispone el legislador. De acuerdo con esto, y en distintas ocasiones, han cambiado por medio de actos legislativos algunos de los artículos más fundamentales del gobierno. [...] Donde no existiese, ni pudiera

63 Cfr. Prakash y Yoo (2003, pp. 956).

64 Cfr. Barnett (2016, p. 23). 
existir una Constitución superior al gobierno, no habría modo de buscar una garantía constitucional semejante a la establecida en los Estados Unidos. (Hamilton, Madison y Jay, 1818, pp. 335-336) 65

En idéntico sentido, en el capítulo XI de sus Lectures on Law, James Wilson explicaba:

En Gran Bretaña no se conoce nada parecido a una constitución propiamente dicha. Lo que se sabe, en ese reino, bajo ese nombre [...] es la criatura y el dependiente del poder legislativo [...]. La autoridad omnipotente del parlamento es el último recurso. [...] El orden de las cosas en Gran Bretaña es exactamente el reverso del orden de las cosas en los Estados Unidos. Aquí, el pueblo es el amo del gobierno; allí, el gobierno es el amo del pueblo. (Hall, 2007, pp. 718-719)

Lo propio ocurre con el voto del Justice William Patterson en el caso Vanhorne's Lessee v. Dorrance de 1795:

Es difícil decir qué es la constitución de Inglaterra; dado que no se reduce a la certeza y precisión escritas, queda totalmente a merced del Parlamento [...] no hay una constitución escrita, ninguna ley fundamental, nada visible, nada real, nada cierto, por el cual una ley pueda ser evaluada. ${ }^{66}$

Es evidente que, ya desde el momento de la revolución, se impuso en los Estados Unidos la idea acerca del rol normativo y jurídicamente superior que tenía la constitución escrita sancionada por el pueblo. Tal como explica Casto (1995), en los Estados Unidos

las constituciones escritas se adoptaron como limitaciones expresas a la teoría y práctica inglesa de la omnipotencia legislativa. Esta distinción entre constituciones escritas y no escritas no era simplemente una cuestión de forma. En el caso de una constitución no escrita, la aprobación del pueblo tenía que inferirse de una larga costumbre y aceptación. Por el contrario, el proceso de reducir una propuesta constitucional por escrito y obtener su aprobación positiva por parte de los representantes del pueblo al ratificar las convenciones estableció claramente la legitimidad de una constitución. A diferencia de las inferencias extraídas de la costumbre, las limitaciones expresas de una constitución escrita tenían una procedencia soberana directa y obvia. (pp. 333-334)

65 Énfasis agregado.

662 U.S. 304, p. 308. Énfasis agregado. 
Algo similar ocurrió con el carácter de límite que este concepto específico y nuevo de constitución tenía para el gobierno federal, en especial para el Congreso. Ese límite al Poder Legislativo, al que se consideraba una criatura de la Constitución a la cual debía su autoridad para legislar, significaba otro cambio radical para la época ya que, diferenciándose de Gran Bretaña, implicaba trasladar la soberanía desde el Poder Legislativo a la Constitución. ${ }^{67}$ Así lo explica, por ejemplo, St. George Tucker:

la revolución estadounidense ha formado una nueva época en la historia de las instituciones civiles, al reducir a la práctica lo que, antes, se suponía que existía solo en las especulaciones visionarias de los escritores teóricos. [...] El mundo, por primera vez desde que comenzaron los anales de sus habitantes, vio un pacto original escrito, formado por las voces libres y deliberadas de individuos dispuestos a unirse en los mismos lazos sociales; exhibiendo así un fenómeno político desconocido en épocas anteriores. [...] Este precedente memorable fue seguido pronto por un número mucho mayor de estados en la unión, y abrió el camino hacia ese instrumento, por el cual la unión de los estados confederados se ha completado desde entonces, y en el que, como intentaremos mostrar en lo sucesivo, la soberanía del pueblo y la responsabilidad de sus servidores son principios establecidos de manera fundamental e inequívoca; en el que se definen los poderes de las diversas ramas del gobierno, y el exceso de ellos, tanto en la legislatura, como en las otras ramas, encuentra límites, que no pueden transgredirse sin ofender a ese poder mayor de quien toda autoridad se deriva entre nosotros; a saber, el PUEBLO. (Tucker, 1803, p. 4)

Ese concepto nuevo de constitución, con sus características peculiares de ser expresión de la soberanía del pueblo, de ser escrita, de tener el carácter de norma jurídica de máxima jerarquía directamente invocable por los ciudadanos y sus abogados en juicio (como hicieron, por ejemplo, Iredell o Hamilton ya antes de la sanción de la Constitución de 1787), así como de imponer límites precisos al Gobierno, especialmente al Poder Legislativo, se combinó con el deber que tenían los jueces bajo el Common Law de decidir los casos y controversias correspondientes a su jurisdicción de acuerdo al derecho vigente. ${ }^{68}$ Desde esta perspectiva, la aplicación de la Constitución como máxima norma del orden jurídico pasó a ser un aspecto más del deber general que tenían que cumplir habitualmente los jueces a la hora de decidir casos. Así, esta novedad institucional derivó en el rol ordinario para todos los jueces que se encontraran frente a una

67 Cfr. Leonard (2006, p. 881).

68 Sobre este último punto, el libro de Philip Hamburger (2008) es de consulta obligada. 
ley que contradijera la constitución de invalidarlas en el caso concreto a través de una declaración de inconstitucionalidad (Althouse, 2010, p. 1123). Por eso es que, como explica Schwartz (1963), no hubo necesidad de mencionar ese rol de los jueces específicamente en la Constitución. El motivo es sencillo: el control judicial de constitucionalidad era considerado y aceptado por la tradición jurídica de la época como una parte esencial del derecho vigente ${ }^{69}$ y por eso se lo consideraba incluido dentro de las atribuciones propias de la función judicial. Desde este punto de vista, Marshall no introdujo novedad alguna en los Estados Unidos y la llamada judicial review no tuvo el origen heroico que se le pretende atribuir.

\subsection{Marbury v. Madison no fue el primer caso en el que un tribunal ejerció el control de constitucionalidad sobre una ley federal en los Estados Unidos. Tampoco el primero en el que se declaró la inconstitucionalidad de una ley federal en ese país}

Por supuesto que la gran mayoría de los convencionales que actuaron en Filadelfia en 1787, o en las convenciones estaduales posteriores que ratificaron la Constitución entre el 7 de diciembre de 1787 y el 29 de mayo de $1790,{ }^{70}$ incluido el propio Marshall, o que casi todos los Justices que actuaron en la Suprema Corte antes de la llegada del célebre Chief Justice al tribunal en 1801 defendieran el deber de invalidar leyes que contradijeran la constitución solo permite corregir el mito acerca de su autoría. Lo propio ocurre con la existencia de numerosos precedentes judiciales a nivel estadual de tribunales que declararon la inconstitucionalidad de una ley con anterioridad a $1803 .{ }^{71}$ De toda esa revisión resulta indiscutible que John Marshall no pudo inventar, ni inventó, el control judicial de constitucionalidad. ${ }^{72}$ Sin embargo, nada de esto le quitaría mérito a su decisión en Marbury v. Madison: seguiría siendo la primera sentencia en la que se declaró la inconstitucionalidad de una ley federal en los Estados Unidos luego de la entrada en vigencia de la Constitución de Filadelfia. Y la contribución de Marshall habría sido, precisamente, permitir que el Tribunal se autoadjudique y establezca de forma definitiva una facultad que la constitución no le reconoció

69 Cfr. Schwartz (1963, p. 17).

70 Delaware fue el primero de los trece estados originales en ratificar la Constitución. Rhode Island, que no participó de la Convención de Filadelfia en 1787, el último.

71 Para Treanor (2005, p. 458), uno de los principales estudiosos de la materia, fueron por lo menos 38 casos y no los escasos 6 o 7 que la doctrina solía citar.

72 O, en palabras de Löffler (2016, p. 153), Marshall no fue el padre del control de constitucionalidad. 
expresamente, pero que todos entendían como necesaria. Esta variante del mito tampoco funciona. Nuevamente, estamos frente a una afirmación errónea que los hechos históricos desmienten.

El estudio del período anterior al ingreso de John Marshall a la Suprema Corte no generó el mismo entusiasmo entre académicos de diversas disciplinas. ${ }^{73}$ Sin embargo, es indispensable para verificar si, efectivamente, Marbury v. Madison fue el primer caso en el que un tribunal federal declaró inconstitucional una ley del Congreso. El estudio de las cortes presididas a partir de su instalación el 19 de octubre de 1789 por el Chief Justice John Jay, quien ejerció la presidencia hasta el 29 de junio de 1795, por el Chief Justice John Rutledge, quien lideró el tribunal desde 12 de agosto hasta el 28 de diciembre de 1795, y por el Chief Justice Oliver Ellsworth, quien hizo lo propio entre el 8 de marzo de 1796 y el 15 de diciembre de 1800 demuestra que Marbury v. Madison fue, como mínimo, el sexto caso en el que la Suprema Corte estadounidense ejerció el control judicial de constitucionalidad sobre una ley del Congreso.

Antes de revisar esos casos anteriores a Marbury, corresponde aclarar que la Suprema Corte no encaró de entrada la tarea de publicar oficialmente sus fallos. ${ }^{74}$ Además, no había obligación de dejar por escrito sus decisiones, aun las más importantes, que eran expuestas de viva voz desde el estrado (Joyce, 1985, p. 1298). Por eso, hasta por lo menos el año 1800, las decisiones escritas de la Corte eran la excepción, no la regla (Davis, 1889, pp. XV-XVI).

Los reportes de las sentencias de la Suprema Corte en sus primeros años estuvieron a cargo de abogados que, por propia iniciativa, entendían que podían generar un ingreso económico al vender esos reportes a jueces, litigantes y al público en general. De ahí que estos reportes no tuvieran desde sus orígenes la precisión y continuidad actual. De hecho, el primer "reportero" de los casos de la Suprema Corte fue un abogado oriundo de Jamaica, Alexander James Dallas, quien empezó su tarea varios años después de que la Suprema Corte dictara su primer fallo. ${ }^{75}$ Dallas reconstruyó, precisamente, el período correspondiente entre 1791 y el año $1800,{ }^{76}$ y lo hizo como un emprendimiento pu-

73 Cfr. Wexler (2006, pp. 1373-1374).

74 Al respecto, ver Joyce (1985, p. 1291).

75 Cfr. O'Connor (2004, pp. 24 y ss.).

76 "Dallas was a pioneer of American case reporting and had much to learn about the Enterprise. His volumes, while very useful to the bar, suffered from several important problems. The first was delay: the Supreme Court cases decided in 1793 weren't published by Dallas until 1798, and the cases decided in 1800 weren't put out until 1807. There was also expense: the reports cost about five dollars a volume, a price well beyond the means of many lawyers of the time. In addition, many cases were 
ramente privado, sin apoyo gubernamental, con un gran esfuerzo personal no exento de dificultades y tropiezos. Frustrado por su falta de éxito, abandonó sus tareas advirtiendo que "he encontrado tan miserable aliento por mis reportes que he determinado juntarlos todos y ofrecérselos a las ratas". ${ }^{7}$

Lo que no destruyeron los roedores lo hicieron el agua y el fuego: parte del archivo de la Corte correspondiente a sus primeros años de actividad fue destruido en sucesivas inundaciones, incendios y una explosión de gas en el Capitolio entre 1814 y $1898 .{ }^{78}$ De ahí que existan importantes fallos que no fueron publicados oficialmente y otros que, para poder ser debidamente reconstruidos, se requiere no solo la lectura de los incompletos reportes de Dallas, sino la revisión de cartas privadas, notas de diarios o fuentes similares, especialmente las minutas de la Suprema Corte del período 1789-1801 que se salvaron de la destrucción y fueron publicadas por The American Journal of Legal History entre 1961 y 1964 (Surrency, 1961a, p. 37). A pesar de las limitaciones referidas, pueden mencionarse los siguientes casos:

\subsubsection{La Invalid Pensions Act Ilega a tribunales: el caso Hayburn (1792)}

La Judiciary Act de 1789 no fue la primera ley del Congreso en ser declarada inconstitucional por la Suprema Corte. Y ese augusto tribunal no fue el primero en declarar inconstitucional una ley federal en los Estados Unidos. El mérito le corresponde a la Corte de Circuito de Pensilvania que, a través de una decisión de los jueces James Wilson, John Blair y Richard Peters, declaró inconstitucional la Invalid Pensions Act de 1792 en el caso Hayburn. Para ser más preciso, el 11 de abril de 1792 es la fecha que marca la primera sentencia de un tribunal federal que, en el marco de un caso concreto, declara inconstitucional una ley del Congreso. Es decir, casi once años antes que Marbury v. Madison.

El Congreso había sancionado el 23 de marzo de 1792 la Invalid Pensions Act que, entre otras cosas, establecía un mecanismo para que soldados heridos durante la guerra de independencia pudieran obtener una pensión por invalidez. ${ }^{79} \mathrm{El}$ artículo 2 de la ley había dispuesto que las cortes federales de circuito

omitted, largely at Dallas's own discretion." (O'Connor, 2004, p. 26)

77 Ver "Dallas, Alexander James" en Hall (2005, p. 247).

78 Cfr. Browning y Glenn (1960, p. 243).

79 United States Statutes at Large, Vol. 1, 2 ${ }^{\text {nd }}$. Congress, $1^{\text {st }}$. Session, Ch. 11, p. 243 (1792) ("An Act to provide for the settlement of the Claims of Widows and Orphans barred by the limitations heretofore established, and to regulate the Claims to Invalid Pensions"). 
recibieran los pedidos para acceder al beneficio en los diversos estados. Hay que recordar que, a pesar de no estar previsto en la Constitución, la Judiciary Act de 1789 obligó a los jueces de la Suprema Corte a integrar las llamadas "cortes de circuito". Esos tribunales federales se integraban periódicamente con dos jueces de la Suprema Corte y un tercer juez federal designado en cada circuito en los distintos estados. La Invalid Pensions Act pretendía aprovechar ese despliegue geográfico de la justicia federal, cuyas Cortes de Circuito podían recibir los pedidos de pensión en varios estados.

La ley obligaba a los jueces federales a analizar las pruebas presentadas por los reclamantes y determinar si les correspondía acceder a la pensión conforme el grado de su invalidez física. También regulaba el tipo de pruebas que los inválidos, que no hubieran desertado durante la guerra, tenían que presentar a los jueces de circuito. A su vez, en su artículo 3, la ley obligaba a los jueces durante un plazo de dos años a permanecer al menos cinco días en cada circuito para poder recibir y atender los reclamos. ${ }^{80}$ Finalmente, el artículo 4 de la ley establecía que las decisiones de esos tribunales federales quedaban, en ciertos casos, sujetas a una revisión administrativa del Secretario de Guerra. Así, a pesar de lo que resolvieran las Cortes de Circuito, el secretario de guerra podía decidir incluir o no a los reclamantes en la lista de pensionados e informar de ello al Congreso. ${ }^{81}$

Apenas unos días después de sancionada la ley, James Wilson se encontró en la calle con el entonces Attorney General Edmund Randolph. Según refiere el propio Randolph en una carta al presidente Washington en el marco de una conversación sobre la constitucionalidad de dos leyes sancionadas por el Congreso, Wilson le advirtió que tanto él como el Justice John Blair dudaban fuertemente acerca de la constitucionalidad de la Invalid Pensions Act. ${ }^{82}$

80 "Sec. 3. [...] And it shall be the duty of the judges of the circuit courts respectively, during the term of two years from the passing of this act, to remain at the places where the said courts shall be holden, five days at the least from the time of opening the sessions thereof, that persons disabled as aforesaid, may have full opportunity to make their application for the relief proposed by this act."

81 "Sec. 4. And be it further enacted, That the Secretary at War, upon receipt of the proofs, certificate and opinion aforesaid, shall cause the same to be duly filed in his office, and place the name of such applicant on the pension list of the United States, in conformity thereto: Provided always, That in any case, where the said Secretary shall have cause to suspect imposition or mistake, he shall have power to withhold the name of such applicant from the pension list, and make report of the same to Congress, at their next session."

82 Carta de Edmund Randolph a George Washington del 5 de abril de 1792: "Both Mr. Blair and Mr. Wilson are now at Trenton. I have never heard Mr. Blair say a syllable upon the subject of the representation bill. Some days ago I met Mr. Wilson in Sixth Street, and he stopped to ask me, whether Mr. Blair had communicated to me an idea, which both of them entertained on a late law of the present session, requiring the judges of the circuit courts to hear applications of 
A comienzos de abril de 1792, William Hayburn, un veterano de la guerra de independencia, se presentó ante la Corte de Circuito de Pensilvania a reclamar su inclusión en la lista de beneficiarios de la pensión. A instancias de James Wilson, el 11 de abril de 1792, la Corte de Circuito rechazó la petición por considerar que la Invalid Pensions Act era inconstitucional. ${ }^{83}$

La decisión de la Corte de Circuito no pasó desapercibida. En la sesión del 13 de abril de 1792 en la Cámara de Representantes, William Vans Murray hizo el siguiente planteo: "Siendo esta la primera vez en que una corte de justicia declara que una ley del Congreso es inconstitucional, la novedad del caso produce una variedad de opiniones con respecto a las medidas a ser tomadas en esta ocasión" (Annals of Congress, 1792, Vol. 3, p. 557).

El 15 de abril de 1792, cuatro días después del fallo, Madison escribía desde Filadelfia al general Henry Lee y destacaba que la declaración de inconstitucionalidad de la ley de pensiones había despertado la atención del público y la inquietud de quienes deseaban que el Congreso no fuera controlado. ${ }^{84}$

Los diarios de la época también recalcaron la importancia de la decisión. ${ }^{85}$ El National Gazette de Filadelfia, por ejemplo, en su edición del 16 de abril de 1792, publicó lo siguiente:

Un corresponsal señala que la última decisión de los Jueces de los Estados Unidos en la Corte de Circuito de Pensilvania, declarando inconstitucional una ley de la actual sesión del Congreso, debe ser motivo de gran satisfacción para todos los

pensioners, invalids \&c. I informed him, that Mr. Blair had not mentioned it to me; but that it was said in town, that they meant to refuse to execute the act. Upon his making a strong remark against its constitutionality, (but by the way I suspect that in this the judges, if they persist, will be found wrong) I observed, that doubts had been entertained by some discerning and respectable men as to the constitutionality of the representation bill. To this he replied, it can never come before me, as a judge, and therefore I will say that congress appear to have forgotten the source, from which representation flows. We immediately separated, without exchanging another word". Se puede acceder a una copia de la carta en la página web de la Biblioteca del Congreso de los Estados Unidos (ver George Washington Papers, Series 4, General Correspondence, en https://www.loc. gov/resource/mgw4.101_1002_1003/?st=gallery).

83 El caso fue decidido en medio de un cuestionamiento abierto de la Suprema Corte al sistema de circuitos que obligaba a los Justices a viajar constantemente, en condiciones muchas veces precarias, y a pasar varios meses fuera de sus hogares. Al respecto, ver Holt (1998, pp. 167-169).

84 Carta de James Madison a Henry Lee del 15 de abril de 1792: "The judges have also called the attention of the public to Legislative fallibility, by pronouncing a law providing for Invalid Pensioners unconstitutional and void; perhaps they may be wrong in the execution of their power, but such an evidence of its existence gives inquietude to those who do not wish Congress to be controuled or doubted whilst its proceedings correspond with their views" (Letters and other writings of James Madison, 1865, Vol. I [1769-1793], J. B. Lippincott \& Co., Filadelfia, p. 554).

85 Cfr. Warren (1922, pp. 72 y ss.). 
republicanos y amigos de la libertad: toda vez que asegura al pueblo la amplia protección de sus derechos y privilegios constitucionales, contra cualquier intento de opresión legislativa o ejecutiva. Y, mientras veamos el ejercicio de esta noble prerrogativa de los jueces en manos de hombres capaces, sabios e independientes, como los que componen el actual sistema judicial de los Estados Unidos; se nos ofrece una esperanza justa de que, no solo se evitarán invasiones futuras, sino también de que cualquier ley existente del Congreso que suponga una afectación de los derechos constitucionales de los individuos o de los estados serán sometidas, oportunamente, a revisión [...]. (National Gazzette, 16 de abril de 1792, p. 195)

El 18 de abril de 1792, los jueces de la Corte de Circuito de Pensilvania enviaron una carta al presidente George Washington explicando las objeciones constitucionales que habían tenido en cuenta en su fallo. En esa carta, incluida en el reporte de Dallas, los jueces Wilson, Blair y Peters expusieron los siguientes argumentos para negarse a aplicar la Invalid Pensions Act ante el pedido de Hayburn: en primer lugar, la violación del Congreso de respetar el principio de separación de los poderes previsto en la Constitución al asignarle a los jueces una tarea que no era de naturaleza judicial, sino administrativa; en segundo lugar, la violación de la independencia del Poder Judicial al prever que sus decisiones podían quedar sujetas a la revisión de un miembro del Poder Ejecutivo y, eventualmente, del Congreso. Finalmente, el deber de los jueces independientes de aplicar la Constitución como norma suprema, tal como surge del juramento al asumir sus funciones. ${ }^{86}$

86 Conforme surge del reporte de Dallas: "The Circuit Court for the District of Pennsylvania, consisting of Wilson, and Blair, Justices, and Peters, District Judge, made the following representation in a letter jointly addressed to the President of the United States on 18 April, 1792: To you it officially belongs to 'take care that the laws' of the United States 'to faithfully executed.' Before you, therefore, we think it our duty to lay the sentiments which, on a late painful occasion, governed us with regard to an act passed by the legislature of the union. The people of the United States have vested in Congress all legislative powers 'granted in the Constitution.' They have vested in one Supreme Court and in such inferior courts as the Congress shall establish 'the judicial power of the United States.' It is worthy of remark that in Congress the whole legislative power of the United States is not vested. An important part of that power was exercised by the people themselves when they 'ordained and established the Constitution.' This Constitution is 'the Supreme Law of the Land.' This supreme law 'all judicial officers of the United States are bound, by oath or affirmation, to support.' It is a principle important to freedom that in government, the judicial should be distinct from and Independent of the legislative department. To this important principle the people of the United States, in forming their Constitution, have manifested the highest regard. They have placed their judicial power not in Congress, but in 'courts.' They have ordained that the 'judges of those courts shall hold their offices during good behavior,' and that 'during their continuance in office, their salaries shall not be diminished.' Congress has lately passed an act to regulate, among other things, 'the claims to invalid pensions.' Upon due consideration, we have been unanimously of opinion that under this act, the circuit court held for the Pennsylvania District could not proceed. 
Los otros jueces de la Suprema Corte, especialmente James Iredell, también cuestionaban la constitucionalidad de la ley federal por motivos similares. ${ }^{87} \mathrm{Sin}$ embargo, a pesar de esos planteos, debido al fin patriótico de la ley, oirían y decidirían gran cantidad de peticiones y reclamos de inválidos de guerra en sus constantes viajes para atender las Cortes de Circuito, pero aclarando que no lo hacían como jueces, sino como "comisionados".

Frustrado frente a la negativa de la Corte de Circuito de Pensilvania de aplicar la Invalid Pensions Act en el caso concreto del reclamo de Hayburn, el 5 de agosto de 1792, Randolph le enviaría una carta al presidente Washington criticando la anulación de la ley federal por parte de los jueces debido a su inconstitucionalidad. Y advirtió que había que limitar de alguna forma el precedente que se había sentado. ${ }^{88}$ Inmediatamente, el Attorney General informó a la Suprema Corte que se presentaría a solicitarle que, de oficio, emitiera una orden (writ of mandamus) a esos jueces de circuito para aplicar la ley federal a pesar de la decisión que habían tomado. ${ }^{89}$ La presentación se hizo en una audiencia el viernes 10 de agosto de 1792 (Surrency, 1961b, p. 170). Al día siguiente, en el Hayburn's case, ${ }^{90}$ antes de permitir a Randolph argumentar que la decisión de la Corte de Circuito de Pensilvania era incorrecta y que había que obligar a sus jueces a que aplicaran la ley federal invalidada, la Corte rechazó el pedido. El rechazo se basó en que el Attorney General no tenía facultades para presentarse a

1st. Because the business directed by this act is not of a judicial nature. It forms no part of the power vested by the Constitution in the courts of the United States; the circuit court must consequently have proceeded without constitutional authority. $2 \mathrm{~d}$. Because if, upon that business, the court had proceeded, its judgments (for its opinions are its judgments) might, under the same act, have been revised and controlled by the legislature, and by an officer in the executive department. Such revision and control we deemed radically inconsistent with the independence of that judicial power which is vested in the courts, and consequently with that important principle which is so strictly observed by the Constitution of the United States. These, Sir, are the reasons of our conduct. Be assured that though it became necessary, it was far from being pleasant. To be obliged to act contrary either to the obvious directions of Congress or to a constitutional principle, in our judgment equally obvious, excited feelings in us which we hope never to experience again." (2 U.S. (2 Dall.), pp. 411-412)

87 Iredell enviaría una nota al presidente Washington el 8 de junio de 1792 (ver 2 U.S. (2 Dall.), pp. 412-414).

88 Carta de Edmund Randolph a George Washington del 5 de agosto de 1792: "It is much to be regretted, that the judiciary, in spite of their apparent firmness in Annulling the pension-law, are not, what some time hence they will be, a resource against the infractions of the constitution [...]. [T] he precedent, fixed by the condemnation of the pension-law, if not reduced to its precise principles, may justify every constable in thwarting the laws" (ver George Washington Papers en https://www.loc.gov/resource/mgw4.102_0336_0341/?sp=2).

89 Cfr. Surrency (1961b, p. 167).

90 Hayburn's case, 2 U.S. (2 Dall.) 409 (1792). 
reclamar en abstracto la aplicación de una ley del Congreso. Frente a esta negativa, Randolph insistió y se presentó nuevamente el mismo día, pero ahora en representación del propio Hayburn (Surrency, 1961b, pp. 171-172). En particular, volvió a reclamar la intervención de la Corte para torcer la negativa de los jueces de aplicar la ley del Congreso. La Suprema Corte decidió posponer el análisis del nuevo pedido de Randolph para el siguiente turno en el mes de febrero de 1793. ${ }^{91} \mathrm{La}$ Corte esperaba de esta forma darle tiempo al Congreso para corregir su evidente error y evitar pronunciarse sobre el fondo en este caso. ${ }^{92}$ La Corte eludió así tener que expedirse sobre el pedido del Attorney General: la reforma sería finalmente sancionada por el Congreso el 28 de febrero de $1793,{ }^{93}$ aunque se generarían dudas también sobre la constitucionalidad de esta nueva ley federal.

Mientras tanto, dado el fin patriótico y humanitario que tenía el régimen legal ideado por el Congreso, algunos jueces de la Corte continuaron ejerciendo el trabajo administrativo como una tarea adicional no judicial. Y, como expliqué, manifestaban hacerlo como "comisionados" por el Congreso. De hecho, así lo hizo Iredell durante un tiempo. ${ }^{94}$ Sin embargo, James Wilson, el impulsor de la declaración de inconstitucionalidad de la Corte de Circuito de Pensilvania, nunca dio el brazo a torcer. ${ }^{95}$ Como explica Maeva Marcus (2019), "Wilson se mantuvo firme en su creencia en la teoría del control judicial de constitucionalidad y no hizo intento alguno para encontrar la forma de hacer cumplir el objeto 'benevolente' de la Invalid Pensions Act”' (p. 157).

Más allá de lo incompleto del reporte del caso, lo cierto es que St. George Tucker (1803, p. 5), en su edición revisada de los Commentaries de Blackstone, cita el caso Hayburn como ejemplo del deber que tienen los jueces de oponerse a las leyes del Congreso que contradigan la Constitución. A su vez, Max Farrand (1908) concluye, con razón, que la evidencia histórica demuestra que

91 En su escueto reporte, Dallas refiere lo siguiente: "The Attorney General then changed the ground of his interposition, declaring it to be at the instance, and on behalf of Hayburn, a party interested; and he entered into the merits of the case, upon the act of Congress, and the refusal of the Judges to carry into effect" (Surrency, 1961b, p. 409).

92 A pesar de no haber decidido el fondo, este caso ha sido citado varias veces por la Suprema Corte. Para una crítica acerca de la forma en la que la Corte citó este precedente, ver Marcus y Tier (1988, p. 527).

93 United States Statutes at Large, Vol. 1, 2" nd Congress, $2^{\text {nd }}$ Session, Ch. 17, p. 324 (1793) ("An Act to regulate the Claims to Invalid Pensions").

94 Cfr. Treanor (2005, p. 536).

95 Así lo reconoce el Justice Iredell en una carta a su esposa, Hannah Iredell, del 30 de septiembre de 1792: "We have had a great deal of business to do here, particularly as I have reconciled myself to the propriety of doing the Invalid-business out of Court. Judge Wilson altogether declines it" (McRee, 1858, p. 361). Énfasis en el original. 
"James Wilson, John Blair y Richard Peters declararon inconstitucional la Invalid Pensions Act de 1792” (p. 285). Lo propio hace Charles Warren (1922, p. 71) en su célebre historia sobre la Suprema Corte de los Estados Unidos. ${ }^{96}$ Sin embargo, este precedente es frecuentemente olvidado y no es tenido en cuenta como lo que realmente es: la primera vez en la que una ley del Congreso es declarada inconstitucional por un tribunal federal en los Estados Unidos; ${ }^{97}$ a instancias, especialmente, de la férrea voluntad de James Wilson.

\subsubsection{John Chandler v. Secretary of War y United States v. Yale Todd (1794)}

El conflicto entre la justicia federal y el Congreso por el régimen previsto en la Invalid Pensions Act no quedó ahí. El Congreso reconoció que la ley de 1793, que fijaba una nueva regulación para el trámite de los reclamos de los inválidos de guerra, se dictaba debido a que la experiencia había demostrado que la norma anterior era inadecuada; en particular porque no impedía la admisión de reclamos improcedentes. Por eso, la nueva ley derogó los artículos 2, 3 y 4 de la ley de 1792. También reguló exhaustivamente el tipo de pruebas a presentar a los jueces de circuito y, en lugar de sujetar el trabajo de esos jueces a la revisión del Secretario de Guerra, esta vez sería el Congreso el que tendría la última palabra..$^{98}$ Además, la ley de 1793 previó la obligación tanto para el Secretario de Guerra como para el Attorney General de obtener una decisión de la Suprema Corte para convalidar aquellas decisiones de los jueces de las cortes de circuito que hubiesen adjudicado una pensión bajo el régimen anterior actuando no como jueces, sino como "comisionados". ${ }^{99}$ Este último punto en especial es el

96 "This action of the Federal Judges, holding for the first time an Act of Congress to be in conflict with the Constitution, at once became the subject of consideration in Congress."

97 En su extenso tratado, Linares Quintana (1978) menciona brevemente el caso y sin entrar en detalle alguno: "En 1792, un tribunal federal de circuito -integrado por los jueces Wilson, Blair y Peters- declaró, por vez primera en Estados Unidos, la inconstitucionalidad de una ley del Congreso" (p. 346).

98 "Sec. 2. And be it further enacted, District judge to transmit list of claims to Secretary at War, That the judge of the district shall transmit a list of such claims, accompanied by the evidence herein directed, to the Secretary for the department of War, in order that the same may be compared with the muster-rolls, and other documents in his office; by whom they are to be stated to Congress and the said Secretary shall make a statement of the cases of the said claimants to Congress, with such circumstances and remarks, as may be necessary, in order to enable them to take such order thereon, as they may judge proper."

99 Luego de aclarar que ninguna persona que no estuviera en el listado de pensionados con anterioridad a la sanción de la anterior ley de 1792 podría obtener la pensión sin haber cumplido con los requisitos de la nueva ley, el artículo 3 dispuso: "Sec. 3. [...] saving however to all persons, all and singular their rights founded upon legal adjudications under the [Invalid Pensions Act of 1792] [...]. 
que generaría un nuevo conflicto constitucional, pero esta vez entre el Congreso y la Suprema Corte.

En cumplimiento de lo previsto en la ley de 1793, de común acuerdo con el Secretario de Guerra, el Attorney General Randolph intentó obtener una decisión de la Suprema Corte acerca de la validez de las pensiones otorgadas por los jueces de circuito actuando como "comisionados". El 6 de agosto de 1793, presentó una moción para que la Corte emitiera una orden (writ of mandamus) al Secretario de Guerra para que incluyera a uno de esos inválidos en la lista de beneficiarios del régimen. Ante la posibilidad del rechazo de la moción debido a que dos de los jueces expresaron su desacuerdo a escucharla en la audiencia oral ya que el beneficiario en cuestión no había aceptado ser representado por el Attorney General, Randolph desistió del planteo. Así se lo comunicó al Secretario de Guerra en una carta en la que le sugirió la posibilidad de armar un caso para poder definir de una vez por todas la validez de las pensiones otorgadas por los jueces de circuito. ${ }^{100}$

Para poder despejar el conflicto constitucional planteado por la saga de la Invalid Pensions Act y su modificación posterior, la Suprema Corte se vería finalmente obligada a decidir sobre el fondo de la cuestión. En John Chandler v. Secretary of War $^{101}$ y United States v. Yale Todd, ${ }^{102}$ dos casos no reportados de 1794, la Suprema Corte declararía por primera vez la inconstitucionalidad de una ley federal. ${ }^{103}$

But it shall be the duty of the Secretary at War, in conjunction with the Attorney General, to take such measures as may be necessary to obtain an adjudication of the Supreme Court of the United States, on the validity of any such rights claimed under the act aforesaid, by the determination of certain persons styling themselves commissioners". Énfasis agregado.

100 Ver carta de Edmund Randolph a Henry Knox del 9 de agosto de 1793 en Lowrie y Franklin (1834, p. 78) ("In consequence of our arrangement I moved the Supreme Court of the United States on Tuesday last for a mandamus to be directed to you, as Secretary of War, commanding you to put on the pension list one of those who had been approved by the judges acting in the character of commissioners. The decision of one case would have involved every other. But two of the judges having expressed their disinclination to hear a motion in behalf of a man who had not employed me for that purpose, and I being unwilling to embarrass a great question with little intrusions, it seemed best to waive the motion until some of the invalids themselves should speak to counsel. To this end I beg leave to suggest the propriety of a letter, from your office to such of the invalids as have been certified to be proper for pensions, and perhaps it may be well to, intimate the turn which the affair has taken and I have just mentioned. It was very unlucky that, although one of the invalids was in court when I made the motion, and heard the difficulty, he omitted to notify himself to me until the court had risen and it was too late").

101 Los pormenores del caso fueron reconstruidos en Sherman (1905, p. 431).

102 Al respecto, ver Ritz (1958, p. 220).

103 Ambos casos fueron tratados en instancia originaria en la Suprema Corte. 
La reconstrucción de los hechos de ambos casos no es sencilla. A diferencia de lo que ocurre con el caso Hayburn, que por lo menos fue reportado en la misma época en la que se decidió (aunque de forma incompleta), no ocurre lo mismo con Chandler y con Yale Todd: ninguno de los dos fue siquiera mencionado por Dallas. En relación con el caso Chandler, decidido el 14 de febrero de 1794, las minutas con el resumen del expediente, certificadas por un secretario de la Suprema Corte, fueron leídas en el Congreso en 1802. ${ }^{104}$ Se conservan también las publicadas por The American Journal of Legal History en 1961 (Surrency, 1961b, pp. 188-193). La existencia del caso Yale Todd, decidido el 17 de febrero de 1794, fue advertida en 1852 por el Chief Justice Roger B. Taney en una nota agregada al final de la decisión del caso The United States v. Ferreira. ${ }^{105}$ En el Archivo Nacional en Washington, D. C. se conservan ocho páginas referidas al caso. ${ }^{106}$

En lo que se refiere a Chandler, según surge de la minuta referida, el caso fue decidido por el Chief Justice John Jay y los Justices James Wilson, John Blair, William Cushing y William Paterson. El 5 de febrero de 1794, el reclamante se presentó ante la Corte con su abogado, un tal "Mr. Edmond", y pidió que se emitiera una orden (writ of mandamus) para que el Secretario de Guerra lo incluyera en la lista de beneficiarios de la pensión prevista en la Invalid Pensions Act (Surrency, 1961b, pp. 188-189). El reclamo se basaba en que Chandler, un exveterano del estado de Connecticut, había sido beneficiado por una decisión de los jueces James Iredell y Richard Law, encargados de la Corte de Circuito en Hartford, de Connecticut, quienes habían ordenado incluirlo en la lista de beneficiarios de la pensión, pero actuando como "comisionados" y no como jueces. Sin embargo, a pesar de esa decisión favorable de los jueces de circuito, no había sido aún incluido en la lista de beneficiarios. Luego de escuchar los argumentos de Chandler en dos audiencias consecutivas (Surrency, 1961b, pp. 190 y 192) y de considerar tanto la ley de 1792 como la de 1793, la Corte rechazó el planteo el 14 de febrero de $1794 .{ }^{107}$

104 Annals of Congress (1802, Vol.. 11, pp. 903-904). La lectura de esas minutas se hizo en el marco de la discusión legislativa previa a la decisión de la Corte en Marbury v. Madison. En esa oportunidad, también se discutió acerca del control judicial de constitucionalidad.

10554 U.S. (13 How.) 40 (1852).

106 Cfr. Dionisopoulos y Peterson (1984, p. 49).

107 "The court having taken into consideration the motion of Mr. Edmond, of the 5th instant, and having considered the two acts of Congress relating to the same, are of opinion, that a mandamus cannot issue, to the Secretary of War, for the purpose expressed in said motion." (Annals of Congress, Vol. 11, p. 904) 
De acuerdo a la reconstrucción parcial que pudo hacer Walter Ritz en los archivos de la propia Corte en 1958, ${ }^{108}$ así como de la nota que Taney ordenó insertar en 1852, surge que el 17 de febrero de 1794, y con la misma integración, la Suprema Corte decidió el caso Yale Todd. A través del nuevo Attorney General, William Bradford, en un caso orquestado de común acuerdo con Todd, ${ }^{109}$ el gobierno federal reclamó la devolución de un monto pagado en concepto de pensión por invalidez bajo la Invalid Pensions Act, declarada inconstitucional en 1792.

Según surge de esos reportes, Todd había hecho un reclamo el 3 de mayo de 1792 pidiendo acceder a la pensión debido a las heridas recibidas durante la guerra de independencia. El reclamo había sido resuelto favorablemente por los jueces John Jay, William Cushing y Richard Law, integrantes de la Corte de Circuito de Connecticut, pero actuando como "comisionados". De hecho, el 5 de mayo de 1792, emitieron un certificado para que el Secretario de Guerra incluyera a Todd en la lista de pensionados. Dadas las dudas acerca de la constitucionalidad del régimen previsto en 1792 y corregido en 1793, el gobierno federal propuso a Todd llevar el caso de común acuerdo y le reclamó la devolución de las sumas pagadas en concepto de pensión. El 17 de febrero de 1794, la Suprema Corte ordenó a Todd devolver las sumas de dinero recibidas de parte del gobierno federal de los Estados Unidos en concepto de pensión bajo la ley federal de $1792 .{ }^{110}$

El mismo día en el que la Corte falló en favor del gobierno federal, Bradford escribió al secretario de Guerra Henry Knox y le avisó acerca de la decisión de la Corte:

108 La copia certificada del reporte del caso por parte de Taney se encuentra en el Archivo Nacional en Washington, D. C. Cfr. Ritz (1958, p. 220). La minuta del caso se transcribe en el artículo en cuestión en las páginas 227 a 231.

109 En la escueta minuta del caso se lo identifica como Amicable Action on the case (Surrency, 1961b, 196). Cabe recordar que el Attorney General había ofrecido al Secretario de Guerra hacer algo similar en la carta citada en la nota 100.

110 Según el Chief Justice Taney, el resultado del caso Todd es el siguiente: "The result of the opinions expressed by the judges of the Supreme Court of that day in the note to Hayburn's Case and in the case of United States $v$. Todd, is this: 1 . That the power proposed to be conferred on the circuit courts of the United States by the act of 1792 was not judicial power within the meaning of the Constitution, and was therefore unconstitutional, and could not lawfully be exercised by the courts. 2. That as the act of Congress intended to confer the power on the courts as a judicial function, it could not be construed as an authority to the judges composing the court to exercise the power out of court in the character of commissioners. 3. That money paid under a certificate from persons not authorized by law to give it might be recovered back by the United States" (54 U.S. (13 How.), p. 53). 
Tengo que reportar que, a consecuencia de las medidas tomadas "para obtener una decisión de la Suprema Corte acerca de la validez de las adjudicaciones de ciertas personas que se consideraban a sí mismas como comisionados bajo la ley del 23 de marzo de 1792", esa corte ha decidido hoy (en el caso Yale Todd) que esas adjudicaciones no son válidas. ${ }^{11}$

El 21 de febrero de 1794, Knox notificó a ambas cámaras del Congreso. ${ }^{112}$ Según consta en los registros de la época, el vicepresidente John Adams leyó una comunicación de Knox refiriéndose a los defectos de la ley sancionada en 1793. A su vez, ese mismo día, en la Cámara de Representantes leyó un reporte del Secretario de Guerra comunicando la decisión de la Corte al Congreso.

Frente a la negativa de la Suprema Corte de aplicar tanto la ley federal de 1792 como la de 1793, el Congreso tuvo que sancionar una nueva ley el 7 de junio de 1794. Allí le ordenó al Secretario de Guerra incluir en la lista de pensionados a aquellos reclamantes que habían sido oídos por los jueces de las cortes de circuito en el carácter de "comisionados" ${ }^{113}$ Los jueces federales pasarían así a dejar de tener cualquier tipo de intervención previa relativa al otorgamiento de las pensiones a los inválidos de guerra.

Tanto Chandler como Yale Todd son considerados por diversos autores como el primer caso en el que la Suprema Corte de los Estados Unidos declaró inconstitucional una ley del Congreso. ${ }^{114} \mathrm{Tal}$ vez, la escasa diferencia de tiempo y

111 Ver "Report of the Attorney General to the Secretary of War", 17 de febrero de 1794, en Lowrie y Franklin (1834, p. 78) ("I have to report, that, in consequence of measures taken "to obtain a decision of the Supreme Court upon the validity of the adjudications of certain persons styling themselves commissioners under the act of the $23 \mathrm{~d}$ of March 1792,' that court has this day determined (in the case Yale Todd) that such adjudications are not valid").

112 Ver "Decision of the Supreme Court on the Validity of Certain Claims for Invalid Pensions", Comunicación del Departamento de Guerra a la Cámara de Representantes, 21 de febrero de 1794, en Lowrie y Franklin (1834, p. 78).

113 Ver United States Statutes at Large, Vol. 1, 3rd Congress, $1^{\text {st }}$ Session, Ch. 57, p. 392 ("An Act concerning Invalids") (1794). En su parte pertinente, la ley de 1794 dispone: "Be it enacted by the Senate and House of Representatives of the United States of America in Congress assembled, That the Secretary of the War department be, and he is hereby directed to place upon the list of invalid pensioners of the United States, all persons who have been returned as such Secretary at War to place certain persons on pension list by the judges of the several districts under the act of Congress of the $28^{\text {th }}$ of February, 1793, intituled 'An act to regulate the claims to invalid pensions,' and who by legal proofs, are by him found to come clearly within the provisions of the said act, and are reported as having complete evidence of their claims in the report of the said secretary upon that subject, made to Congress the $25^{\text {th }}$ day of April, 1794; and all persons placed by virtue of this act on the list of invalid pensioners, shall receive such sums as the returns of the district judges have respectively specified, and be paid, in the same manner as invalid pensioners are paid, who have been heretofore placed on the list [...]".

114 Ver, por ejemplo, Sherman (1905, pp. 437-438) (Chandler); Ritz (1958, p. 227) (Yale Todd); 
el hecho de no haber sido reportados explique esa confusión. Lo cierto es que Chandler fue resuelto tres días antes que Yale Todd. Y, cualquiera sea la opinión que se tenga sobre ambos casos, resulta indiscutible que la Suprema Corte dejó de aplicar en ellos dos leyes del Congreso. Tan es así que el Congreso tuvo que sancionar una tercera ley para poder convalidar la actuación de los jueces de circuito que, actuando como comisionados, habían decidido otorgar pensiones a cierto grupo de inválidos de guerra. Dicho de otro modo, debido a las objeciones constitucionales planteadas en cuanto al rol de los jueces federales de circuito bajo las leyes federales de 1792 y 1793, la Suprema Corte se negó a convalidar su actuación. Por eso es que el Congreso se vio forzado a ratificar y dar validez a las decisiones tomadas por esos jueces de circuito a través de la ley de 1794 .

A pesar de ello, podría haber quien plantee que, al no existir un registro del contenido de ambas decisiones, no estaríamos frente una declaración de inconstitucionalidad de parte de la Suprema Corte. Cualquiera sea el caso, tal como explica Whittington (2019, p. 69), tomados en su conjunto, los casos relacionados con las leyes federales para otorgar pensiones por invalidez a veteranos de guerra muestran a los jueces determinados a defender la autonomía institucional de los tribunales y rehusarse -basados en argumentos constitucionales- a implementar una política federal que violaba esas reglas fundacionales. Y, además, a obligar al Congreso a tratar de corregir esos defectos constitucionales a través de sucesivas leyes. Si no se trata de un ejercicio del control judicial de constitucionalidad, se le parece bastante.

\subsubsection{Hylton v. United States (1796)}

Dos años después, en el caso Hylton v. United States ${ }^{115}$ se cuestionó la constitucionalidad de la Carriage Act de 1794. A través de esta ley federal, el Congreso había fijado un impuesto anual sobre carretas y carruajes con valores que iban de un dólar por los vehículos básicos de dos ruedas hasta diez dólares por los carruajes más grandes.

Dionisopoulos y Peterson (1984, p. 72) (Chandler); etc. Treanor (2005, p. 537), en cambio, descarta a Chandler y expresa fuertes dudas a favor de Yale Todd. Sin embargo, llama la atención que en un estudio tan exhaustivo haya omitido analizar el informe del Attorney General Bradford al Secretario de Guerra y la ley de junio de 1794. Más allá de la imposibilidad de arribar a conclusiones contundentes por la falta de un documento que dé cuenta del razonamiento expuesto por los jueces en su fallo, lo cierto es que hay indicios más que importantes que sugieren que, al menos en el caso de Yale Todd, la Corte efectivamente invalidó una ley federal basándose en su inconstitucionalidad. Máxime cuando, en el caso del Chief Justice Jay y del Justice Cushing, la sentencia en Yale Todd implicaba revertir lo que habían decidido actuando en la corte de circuito.

1153 U.S. (3 Dall.) 171 (1796). 
Ya en el debate en el Congreso se habían planteado dudas acerca de la constitucionalidad del impuesto, debido a que no quedaba claro si era o no un impuesto directo y, en su caso, si correspondía que se fijara en proporción a la población de cada estado, tal como fijaba la Constitución. ${ }^{116}$

El nuevo impuesto encontró una rápida resistencia en algunos estados, especialmente en Virginia. Dos jueces de la corte estatal, Edmund Pendleton y Spencer Roane, se negaron a pagarlo. Dadas las dudas de Alexander Hamilton acerca de la constitucionalidad de la medida, al igual que en el caso Yale Todd, el Gobierno de los Estados Unidos buscó la forma de generar un caso de común acuerdo con el potencial demandado para permitir que la Suprema Corte determinara la validez constitucional del nuevo impuesto.

Daniel Lawrence Hylton fue la persona elegida para ser demandado por los Estados Unidos ante la Corte de Circuito de Virginia. ${ }^{117}$ Como parte de su defensa, ejercida por John Taylor de Caroline, Hylton planteó que la Carriage Act de 1794 era inconstitucional dado que los ciento veinticinco carruajes que tenía eran solo para uso personal y, además, al ser un impuesto directo, no había sido determinado de forma proporcional entre los estados conforme lo previsto en el artículo I, sección 2, cláusula 3 de la Constitución de $1787 .{ }^{118} \mathrm{Du}$ rante las actuaciones seguidas en la Corte de Circuito de Virginia, Taylor hizo una encendida defensa del control judicial de constitucionalidad. Planteó que la Constitución era un baluarte contra las mayorías legislativas que interponía al Poder Judicial entre el Gobierno y los individuos. Los jueces eran así los encargados de asegurar que el Congreso no se extralimitara en el ejercicio de sus atribuciones y la forma de hacerlo era controlar la constitucionalidad de sus acciones, sin influencias políticas y en el marco de un debate judicial libre. ${ }^{119}$

116 Ver sesión de la Cámara de Representantes del 29 de mayo de 1794 en Annals of Congress (1794, Vol. 4, pp. 729-730). Tal como explicaré más adelante, casi cien años después, la Suprema Corte analizaría si el impuesto a las ganancias era o no un impuesto directo y desataría una fuerte polémica por una decisión que declaraba inconstitucional una ley federal en 1895. Esas reacciones darían origen al mito de Marbury.

117 Hylton sería parte de otro importante caso de la época: Ware v. Hylton (3 U.S. (3 Dall.) 199 [1796]), en el que la Corte invalidó una ley del estado de Virginia que contradecía el Tratado de Paz de 1783. John Marshall fue uno de los abogados del estado de Virginia en ese caso y, llamativamente, planteó que: "The judicial authority can have no right to question the validity of the law; unless such a jurisdiction is expressly given by the constitution" (3 Dall., p. 211).

118 En su parte pertinente, el artículo I, sección 2, cláusula 3 de la Constitución de 1787 dice: "Los representantes y los impuestos directos se prorratearán entre los distintos estados que formen parte de esta Unión, de acuerdo con su población respectiva [...]".

119 Cfr. Frankel (2003, p. 6). 
La Suprema Corte había sido parcialmente renovada con el ingreso del Justice Samuel Chase, el 27 de enero de 1796. El caso fue presentado en sucesivas audiencias el 23, 24 y 25 de febrero de 1796 (Surrency, 1963a, pp. 71-72). La decisión fue tomada el 8 de marzo de 1796, fecha de ingreso a la Corte del Chief Justice Oliver Ellsworth, que decidió no participar de la decisión. Tal como surge del reporte de Dallas, el caso tenía como fin determinar la constitucionalidad o no del impuesto. ${ }^{120}$ Entre los abogados del gobierno federal estaba Alexander Hamilton, que buscaba que la Corte convalidara la validez constitucional del impuesto. La Suprema Corte terminaría decidiendo que el impuesto a los carruajes no era un impuesto directo y que, por lo tanto, no violaba ni el artículo I, sección 2, cláusula 3 ni el artículo I, sección 9, cláusula 3 de la Constitución, que requieren fijar impuestos directos en proporción a la población de cada estado. La Corte consideró que los impuestos directos no incluían a los impuestos a la posesión de bienes.

Los jueces de la Corte destacaron que estaban ejerciendo el control de constitucionalidad sobre el impuesto establecido por el Congreso. El Justice William Paterson, por ejemplo, destacó que:

La pregunta es si ¿un impuesto sobre los carruajes es un impuesto directo? Si se trata de un impuesto directo, es inconstitucional, ya que se ha establecido de conformidad con la regla de uniformidad y no con la regla de distribución [en proporción a la población de cada Estado]. ${ }^{121}$

Los Justices Chase e Iredell hicieron consideraciones similares, aunque el recién ingresado Chase pareció dudar acerca de la facultad de los jueces de ejercer el control de constitucionalidad. ${ }^{122}$ Finalmente, el Justice Wilson sostuvo que no tenía dudas acerca de la constitucionalidad del impuesto. ${ }^{123}$

Si bien la Suprema Corte terminaría convalidando la ley federal cuestionada por Hylton, lo cierto es que los jueces ejercieron efectivamente el control de constitucionalidad y lo reconocieron expresamente (Frankel, 2003, p. 11). De hecho, se trata del primer caso reportado de control de constitucionalidad de una ley del Congreso por parte de la Corte. ${ }^{124}$

1203 U.S. (3 Dall.), p. 172.

1213 U.S. (3 Dall.), p. 176. En su voto, Paterson se basa en la intención del constituyente para determinar el alcance del poder del Congreso en materia de impuestos (ídem).

1223 U.S. (3 Dall.), p. 175.

1233 U.S. (3 Dall.), pp. 183-184.

124 Cfr. Whittington (2019, p. 71). Whittington sostiene que ese mismo año la Corte convalidó otra ley federal cuestionada por inconstitucional en el caso United States v. La Vengeance, 3 U.S. 297 (3 Dall.) 


\subsubsection{La duda de Chase}

La duda planteada por Chase sería rápidamente despejada. El Justice Chase había sido uno de los firmantes de la Declaración de la Independencia del 4 de julio de 1776. Fue designado por el presidente Washington como Justice de la Suprema Corte a comienzos de 1796. No conocía medias tintas: era agresivo y militante en todo lo que hacía. Sin embargo, su pensamiento había sufrido una mutación entre la sanción de la Constitución de 1787 y su ingreso a la Corte. De hecho, había mantenido una postura antifederalista en relación con la Constitución de $1787 .{ }^{125} \mathrm{Su}$ cambio de pensamiento se explicaría por la aversión que sentía por la Revolución Francesa y el intento de los republicanos de imponer sus ideas en los Estados Unidos.

Además de hacer una interpretación que tendría gran influencia acerca de la irretroactividad solamente sobre leyes penales en Calder v. Bull, ${ }^{126}$ Chase sostuvo que cualquier ley "contraria a los grandes primeros principios del pacto social" debe ser declarada nula. En esta opinión enfatizó que la Constitución constituía un límite al legislador.

Posteriormente, en United States v. Callender, ${ }^{127}$ defendió también el poder de los jueces federales al decidir que los jurados no podían pronunciarse acerca de la constitucionalidad de las leyes:

Debe recordarse que el Poder Judicial de los Estados Unidos es coexistente, coextensivo y coordinado con, y a su vez totalmente independiente de, la legislatura federal, o del Ejecutivo. A través del artículo sexto de la Constitución, entre otras cosas, se declara que la Constitución será la ley suprema del país. Por el tercer artículo, se establece que "El poder judicial de los Estados Unidos será conferido a una Suprema Corte y a los tribunales inferiores que el Congreso pueda ordenar y establecer de tiempo en tiempo; y que el poder judicial se extenderá a todos los casos de derecho y equidad, que surjan bajo la constitución y las leyes de los Estados Unidos." Entre los casos que pueden surgir bajo la Constitución, se encuentran todas las restricciones a la autoridad del Congreso y de las legislaturas estatales. Es muy claro que el presente caso surge bajo la Constitución y también bajo una ley de los Estados Unidos, por lo tanto, es la misma posibilidad a la que la Constitución declara que los poderes judiciales de los Estados Unidos se extenderán. Es incontrovertible que la Constitución es la ley suprema y, por ende, debe ser la regla por la cual los jueces federales y estatales están obligados a regular sus decisiones. ${ }^{128}$

(1796) (2019, p. 72).

125 Al respecto, ver Haw (1981, p. 272).

1263 U.S. (Dall.) 386 (1798).

12725 F. Cas. 239, No. 14, 709 (C.C. Va.) (1800).

12825 F. Cas., p. 256. 
Chase vinculó también el control judicial de constitucionalidad con el juramento de defender la Constitución previsto en el artículo VI, sección 3 y el mecanismo de reforma de la Constitución previsto en el artículo V:

Según el artículo sexto de la constitución, se establece (entre otras cosas) que todos los miembros del congreso, y de las diversas legislaturas estatales, y todos los funcionarios judiciales de los Estados Unidos, y de los diversos estados, estarán obligados a defender la constitución por un juramento o afirmación. Por esta disposición, entiendo que cada persona, tanto juramentada como afirmada, promete que preservará la constitución tal como está establecida, y la distribución de poderes otorgada de ese modo; y que no aceptará ninguna enmienda o alteración de la misma, sino en la forma prescrita en el artículo quinto; y que no dará su consentimiento a ninguna usurpación por parte de una rama de la legislatura sobre la otra, o sobre el ejecutivo, o por el ejecutivo sobre cualquiera de las ramas, o por cualquier departamento o funcionario del gobierno, del poder otorgado a otro; o que el poder otorgado a cualquiera sea ejercido por otros. También entiendo por este compromiso, que la persona que lo toma, promete también que se opondrá por su ejemplo, argumento, consejo y persuasión, y por todos los demás medios en su poder, salvo la fuerza, a cualquier diseño, consejo o intento de deteriorar o destruir la constitución. Si la exposición de esta obligación solemne es sustancialmente correcta, no puedo creer que cualquier persona que tenga la misma comprensión de ella sostenga que un pequeño jurado pueda ejercer legítimamente el poder otorgado por la constitución al poder judicial federal. ${ }^{129}$

Chase concluyó que solamente el Poder Judicial podía ejercer el control de constitucionalidad de las leyes. ${ }^{130}$

A partir de estas consideraciones, saco esta conclusión: que el poder judicial de los Estados Unidos es la única autoridad apropiada y competente para decidir si alguna ley sancionada por el Congreso (o cualquiera de las legislaturas estatales) es contraria a, o se sanciona en violación de, la constitución federal. [...] Creo que ha sido la opinión general y prevaleciente en toda la Unión, que el poder que ahora quiere ejercer un jurado, pertenece propiamente a los tribunales federales. ${ }^{131}$

La actuación de Chase en este caso disparó, junto con otras acusaciones,

129 Ídem.

130 Según Presser (2002, p. 1507), Marshall estaba entre el público cuando Chase hizo esta alocución al jurado y luego repitió en Marbury lo dicho por Chase.

13125 F. Cas., p. 256. 
un célebre procedimiento de remoción impulsado por el presidente Jefferson. Como es sabido, Chase fue el único Justice de la Suprema Corte en ser sometido a impeachment en la historia de los Estados Unidos. Su absolución tuvo un gran impacto en la consolidación de la independencia del Poder Judicial y, por ende, en la del control judicial de constitucionalidad. ${ }^{132}$ Ejerció el cargo de Justice hasta su muerte, el 9 de junio de 1811.

\subsubsection{Hollingsworth v. Virginia; Brailsford v. Georgia y Moultrie v. Georgia (1798)}

El 8 de enero de 1798, el presidente John Adams anunció al Congreso que la Enmienda XI había sido ratificada por la cantidad de estados requerida por la Constitución para poder entrar en vigencia. ${ }^{133}$ Esa enmienda constitucional había sido impulsada para revertir la decisión de la Suprema Corte en el caso Chisholm v. Georgia, ${ }^{134}$ que reconoció la competencia originaria de la Corte en los casos en los que un ciudadano de un estado había demandado a otro estado. Unas semanas después del anuncio de la entrada en vigencia de la enmienda constitucional, a instancias del Attorney General Charles Lee, la Corte desestimó todos los casos pendientes en una sentencia muy conocida, Hollingsworth v. Virginia, ${ }^{135}$ y en dos casos no reportados por Dallas: Brailsford v. Georgia y Moultrie v. Georgia.

De las minutas correspondientes al 14 de febrero de 1798 surge que los Justices Chase, Cushing, Iredell y Paterson resolvieron estos tres casos en orden y del siguiente modo: "La Corte opina que, en consideración de la Enmienda de la Constitución relacionada con los juicios contra los Estados, no tiene jurisdicción sobre esta causa". ${ }^{136}$ En todos estos casos, la Corte aplicó retroactivamente la Enmienda XI e invalidó así el artículo 13 de la Judiciary Act de 1789, que había permitido esos reclamos entre ciudadanos de un estado contra otro estado. ${ }^{137}$ Aunque reconoce la peculiaridad de estos casos, Treanor $(2005$, p. 547)

132 Analicé este impeachment en detalle en García-Mansilla (2016, pp. 185-214).

133 Annals of Congress (1798, Vol. 8, p. 809). La Enmienda XI dispone: "The Judicial power of the United States shall not be construed to extend to any suit in law or equity, commenced or prosecuted against one of the United States by Citizens of another State, or by Citizens or Subjects of any Foreign State".

1342 U.S. (2 Dall.) 419 (1793).

1353 U.S. (3 Dall.) 378 (1798).

136 Cfr. Surrency (1963b, p. 267).

137 En su parte pertinente, el artículo 13 de la Judiciary Act de 1789 disponía: "That the Supreme Court shall have exclusive jurisdiction of all controversies of a civil nature, where a state is a party, 
afirma que la Corte ejerció en los tres el control judicial de constitucionalidad, ya que una ley federal terminaría siendo invalidada por ser inconsistente con la Constitución.

Desde una perspectiva similar, uno de los principales estudiosos de la historia de la Suprema Corte afirma que el caso Hollingsworth debería descartar el saber convencional que indica que Marbury fue la primera vez en la que la Suprema Corte declaró inconstitucional una ley del Congreso. Currie (1981, p. 842) sostiene que el artículo 13 de la Judiciary Act de 1789, que la Corte en Chisholm había interpretado que autorizaba las demandas de un ciudadano de un estado contra otro estado en la Suprema Corte, todavía estaba vigente en 1798 y no había sido modificado. Pero la Corte lo trató como si no fuera derecho vigente debido a la aprobación de la Enmienda XI, es decir, por su inconstitucionalidad sobreviniente.

Del reporte de Dallas surge que, como parte de la decisión en Hollingsworth, la Corte tuvo que atender un cuestionamiento acerca de la invalidez de la reforma constitucional por no haber sido enviada al Ejecutivo para su aprobación. ${ }^{138}$ La Corte analizó la atribución que ejerce el Congreso en el proceso de enmienda y sostuvo que no es de carácter legislativo y que, por ende, no puede ser objeto de un veto por parte del Presidente. En su voto, el Justice Samuel Chase sostuvo: "El caso de las enmiendas es evidentemente un acto sustantivo, desconectado del trabajo ordinario de la legislación, y no está dentro de la política, o los términos, que confieren al Presidente un veto sobre las leyes y resoluciones del Congreso". ${ }^{139}$

Llama la atención que aquellos que sostienen que el control judicial de constitucionalidad nació con el célebre Marbury v. Madison olviden que en $\mathrm{Ho}$ llingsworth la Corte controló no ya una ley, sino nada menos que el proceso de reforma constitucional que derivó en la aprobación de la Enmienda XI. Y lo hizo cinco años antes que Marbury. Por eso, se ha dicho con cierta razón que: "El control judicial de constitucionalidad sobre el proceso de enmienda constitucional es, en cierto sentido, más antiguo que la propia revisión judicial de las leyes" (Dellinger, 1983, p. 403).

except between a state and its citizens; and except also between a state and citizens of other states, or aliens, in which latter case it shall have original but not exclusive jurisdiction". Ese mismo artículo es el que sería invalidado en Marbury v. Madison.

1383 U.S., p. 379.

1393 U.S., p. 381. 


\subsubsection{El caso Mossman (1800)}

Algunos autores incluyen al caso Mossman v. Higginson ${ }^{140}$ como un caso de control judicial de constitucionalidad. Según Whittington (2019, pp. 73-74), "en el año 1800, tres años antes que Marbury, la Suprema Corte bajo el Chief Justice Oliver Ellsworth invalidó por primera vez un aspecto de la Judiciary Act de 1789".

En Mossman se discutía la aplicación del artículo 11 de la Judiciary Act de 1789 en cuanto extendía la jurisdicción federal de las cortes de circuito a los casos en los que un extranjero fuera parte. ${ }^{141}$ Esa referencia de la ley a los casos en los que un extranjero fuera parte no tenía sustento en el texto de la Constitución de 1787.

El caso surgió a raíz de una demanda presentada por un mercader británico de apellido Higginson en un tribunal federal de circuito para cobrar una vieja deuda. La demanda se había iniciado en un tribunal federal bajo el artículo 11 de la Judiciary Act de 1789. Los abogados de Mossman, que era albacea del deudor fallecido, alegaron que no surgía del expediente que alguna de las partes fuera un ciudadano norteamericano. Además, alegaron que el Congreso no podía ni alterar ni extender a través de una ley las disposiciones de la Constitución, que no establecía en ninguna parte la jurisdicción federal para los juicios entre dos extranjeros. ${ }^{142}$ La Suprema Corte le dio la razón a Mossman. A pesar de lo establecido en el texto de la Judiciary Act de 1789, la Corte explicó que el poder del Congreso para establecer la jurisdicción federal estaba limitado a los casos entre ciudadanos y extranjeros y que la ley debía interpretarse de esa forma. ${ }^{143}$

Si bien el reporte del caso es también escueto, lo cierto es que la Corte ejerció efectivamente el control de constitucionalidad de la Judiciary Act de 1789, y lo

1404 U.S. 12 (1800).

141 En su parte pertinente, el artículo 11 de la Judiciary Act de 1789 establecía que: "That the circuit courts shall have original cognizance, concurrent with the courts of the several States, of all suits of a civil nature at common law or in equity, where the matter in dispute exceeds, exclusive of costs, the sum or value of five hundred dollars, and the United States are plaintiffs or petitioners; or an alien is a party, or the suit is between a citizen of the State where the suit is brought and a citizen of another State". Énfasis agregado.

1424 U.S., p. 13.

143 "[T]he 11th section of the judiciary act can, and must, receive a construction, consistent with the constitution. It says, it is true, in general terms, that the Circuit Court shall have cognizance of suits 'where an alien is a party;' but as the legislative power of conferring jurisdiction on the federal Courts, is, in this respect, confined to suits between citizens and foreigners, we must so expound the terms of the law, as to meet the case, 'where, indeed, an alien is one party,' but a citizen is the other." (4 U.S., p. 14) 
hizo a través de una peculiar interpretación del texto de la ley para poder ajustarla a la Constitución. ${ }^{144}$ Algunos podrían alegar, no sin cierta razón, que estamos frente a un ejercicio temprano de lo que la doctrina europea denominaría modernamente como "interpretación conforme con la Constitución".

\subsubsection{Conclusión}

Marbury no fue el primer caso en el que un tribunal federal controló la constitucionalidad de una ley del Congreso en los Estados Unidos. Tampoco el primero en el que se declaró inconstitucional una ley del Congreso.

De la revisión de los casos reseñados ${ }^{145}$ surge que, tal como explica Whittington (2019), Marbury v. Madison fue la sexta (o la séptima, agrego yo) ocasión en la que la Suprema Corte de los Estados Unidos ejerció de forma sustantiva el control de constitucionalidad de legislación federal desde 1789. Y también es la tercera (o la cuarta, agrego yo) en la que un tribunal federal se rehusó a aplicar una ley del Congreso en un caso concreto por considerarla inconsistente con la Constitución. ${ }^{146} \mathrm{~A}$ pesar de que en la actualidad se la sigue evocando como la sentencia que estableció el control judicial de constitucionalidad, lo cierto es que en la época no generó esa apreciación. De hecho, los contemporáneos de Marshall no trataron el caso como una decisión trascendente que hubiera creado un nuevo poder o decidido algo especialmente importante en relación con el rol de los jueces (Whittington, 2009, p. 1286). Incluso más de un siglo después, en su clásico estudio sobre la Corte, Warren (1922, pp. 231 y ss.) lo denomina como "el caso del mandamus" ("the mandamus case"). Cabe tener en cuenta, además, que en muchos de los casos reseñados hay evidencias que demuestran que eran los propios abogados de las partes los que planteaban la eventual inconstitucionalidad de las leyes. Esto sugiere claramente la aceptación generalizada del control judicial de constitucionalidad de las leyes a nivel federal. ${ }^{147}$ Por ello, es que no llama la atención que parte de la doctrina moderna en los Estados Unidos afirme ahora que la famosa sentencia de Marshall

144 Según Currie (1981, p. 851), la Corte se tomó por primera vez en este caso la libertad de interpretar una ley federal de modo tal de evitar tener que declarar su inconstitucionalidad.

145 Parte de la doctrina norteamericana incluye otros casos, como el voto en disidencia de James Iredell en United Sates v. Ravara de 1793 (Treanor, 2005, pp. 538-540). No lo incluyo porque existe muy poco material de peso como para poder analizar y formarse algún tipo de convicción al respecto.

146 Cfr. Whittington (2019, p. 81).

147 Se ha dicho, con razón, que "judicial review [...] was part of the legal spirit of the time" (Schwartz, 1963, p. 18). 
"es bastante menos importante de lo que comúnmente se supone" (Klarman, 2001, p. 1113). ${ }^{148}$

\subsection{Dred Scott $v$. Sandford no fue el segundo caso en el que la Suprema Corte declaró inconstitucional una ley del Congreso}

En algunas de sus variantes, el mito de Marbury va también acompañado de un cuestionamiento implícito: dado que Marshall había logrado que los jueces federales se autoadjudicaran la judicial review en medio de un conflicto político, fueron prudentes en no volver a ejercer esa extraordinaria facultad. Y cuando volvieron a hacerlo en 1857, ayudaron a desatar la Guerra Civil norteamericana.

Esa afirmación, que aparece solamente en las posturas más extremas de aquellos que sostienen la fábula acerca de los orígenes supuestamente peculiares del control judicial de constitucionalidad, es falsa. En un libro minucioso publicado en 2019, Whittington demuestra que entre 1789 y 1863 la Suprema Corte evaluó de forma sustantiva la constitucionalidad de leyes federales en nada menos que sesenta y dos ocasiones. Durante ese período, la Corte limitó o declaró la invalidez de leyes federales en el 32\% de los casos, número que supera el promedio del 26\% que tiene el tribunal entre 1789 y 2019 (lo que también desmiente empíricamente el carácter supuestamente contramayoritario de la judicial review) (Whittington, 2019, p. 62). Es decir que el ejercicio del control de constitucionalidad fue mucho más habitual en la época de lo que se supone.

Además, hay que tener en cuenta que, en los primeros años de la República, la Suprema Corte no tuvo tantos planteos judiciales con cuestiones constitucionales para resolver. De hecho, hasta 1820 , resolvería un promedio de menos de un caso por año en el que tuviera que ejercer el control y revisión de la constitucionalidad de una ley federal. Sin embargo, a partir de 1830, la Corte resolvería uno o más por año, especialmente a partir de la presidencia de Andrew Jackson (Whittington, 2009, p. 1268).

Si bien existe discusión sobre algunos de esos precedentes en los que la Corte ejerció el control judicial de constitucionalidad antes de Dred Scott, ${ }^{149}$ lo cierto es que los casos fueron, como mínimo, más de cincuenta. ${ }^{150} \mathrm{~A}$ modo de ejemplo, aun durante la presidencia de Marshall, la Corte tuvo que resolver planteos

148 Aclaro que no comparto todas las críticas que Klarman hace a la sentencia en sí.

149 Ver, por ejemplo, Mahoney (1982, p. 725).

150 El listado completo de esos casos se puede consultar en Whittington (2009, pp. 1330-1331). 
de inconstitucionalidad de leyes federales relacionadas con la delegación legislativa, ${ }^{151}$ con cuestiones impositivas, ${ }^{152}$ con problemas asociados al otorgamiento de tierras, ${ }^{153}$ al derecho a ser juzgado mediante el juicio por jurados, ${ }^{154}$ etc. Con el cambio paulatino en su integración, así como su transición a la presidencia del Chief Justice Roger B. Taney, la Suprema Corte no solo continuaría ejerciendo el control judicial de constitucionalidad sobre leyes federales, sino que lo haría de forma más frecuente. Y, tal como explica Whittington (2009, p. 1308), varias veces encontró que tanto la redacción como la aplicación de varias leyes federales excedían la autoridad constitucional del Congreso. Así lo hizo, por ejemplo, en materia de federalismo en el marco de disputas por tierra, ${ }^{155}$ para proteger el derecho de propiedad, ${ }^{156}$ para extender la jurisdicción federal en casos de almirantazgo, ${ }^{157}$ para limitar el poder del Congreso sobre los nuevos estados, ${ }^{158}$ etcétera.

Una vez más recurro a Whittington (2009), quien afirma que:

La práctica de revisar la constitucionalidad de la legislación federal y sus aplicaciones se desarrolló gradualmente a lo largo de las primeras décadas de la república. Esa práctica no consistió en un solo caso inventando el poder de la judicial review y otro, décadas más tarde, utilizando ese poder de manera impactante. A lo largo de los primeros años de la república, se le pidió rutinariamente a la Suprema Corte que resolviera cuestiones constitucionales relacionadas con el alcance de la autoridad legislativa del Congreso y que impusiera límites constitucionales contra esa rama coordinada del gobierno nacional. La Corte alentó rápidamente a los litigantes a plantear estas cuestiones, ya que expresó pocas dudas acerca de su propia responsabilidad para evaluar la constitucionalidad de las acciones legales que se le pedía tomar en los casos que se le presentaron y de negarse a aplicar las leyes federales de formas que excedieran la autoridad del Congreso. Aunque esos desafíos constitucionales dieron como resultado que la

151 Ver, por ejemplo, Aurora v. United States, 11 U.S. (7 Cranch) 382 (1813); United States v. Smith, 18 U.S. (5 Wheat.) 153 (1820); y Wayman v. Southard, 23 U.S. (10 Wheat.) 1 (1825).

152 Loughborough v. Blake, 18 U.S. (5 Wheat.) 317 (1820).

153 Reynolds v. M'Arthur, 27 U.S. (2 Pet.) 417 (1829) y United States v. Percheman, 32 U.S. (7 Pet.) 51 (1833).

154 Parsons v. Bedford, 28 U.S. (3 Pet.) 433 (1830) y United States v. Phelps, 33 U.S. (8 Pet.) 700 (1834).

155 Mayor of New Orleans v. United States, 35 U.S. (10 Pet.) 662 (1836) y Pollard v. Hagan, 44 U.S. (3 How.) 212 (1845).

156 Lylte v. Arkansas, 50 U.S. (9 How.) 314 (1850).

157 Propeller Genesee Chief v. Fitzhugh (The Genesee Chief), 53 U.S. (12 How.) 443 (1851); N.J. Steam Navigation Co. v. Merchants' Bank of Boston, 47 U.S. (6 How.) 344 (1848); y Waring v. Clarke, 46 U.S. (5 How.) 441 (1847).

158 Benner v. Porter, 50 U.S. (9 How.) 235 (1850) y McNulty v. Batty, 51 U.S. (10 How.) 72 (1850). 
Corte aprobara, generalmente, la política federal, la Corte se constituyó en un foro dentro del cual los argumentos constitucionales podían ser planteados y decididos. (p. 1325)

En definitiva, los casos Marbury y Dred Scott, más allá de su innegable importancia, son apenas la punta del iceberg y no todo el edificio del control judicial de constitucionalidad construido entre 1787 y $1857 . .^{159}$

\section{La construcción de la historia oficial en los Estados Unidos}

A la luz de lo expuesto, llama la atención que el mito de Marbury se haya impuesto con tanta contundencia. Máxime cuando, entre 1803 y 1894, la célebre sentencia de Marshall fue citada solamente una vez por la Suprema Corte como precedente acerca de la posibilidad que los jueces federales tienen para imponer límites constitucionales al Congreso. ${ }^{160}$ En efecto, a pesar de los numerosos casos en los que la Corte declaró la inconstitucionalidad o limitó la aplicación de una ley federal en los Estados Unidos durante ese período de tiempo, la Corte citó Marbury v. Madison por primera vez en su historia en un caso similar recién en $1887 .^{161}$

En los libros o artículos de doctrina referidos a cuestiones relacionadas con el control judicial de constitucionalidad que fueron publicados durante esos años no se hace especial referencia a Marbury, sino que se lo menciona como

159 Cfr. Whittington (2019, p. 60).

160 Cfr. Clinton (1989, pp. 28-33).

161 La cita aparece en el caso Mugler v. Kansas, 123 U.S. 623 (1887): "While every possible presumption is to be indulged in favor of the validity of a statute (Sinking Fund Cases, 99 U.S. 718), the courts must obey the Constitution, rather than the lawmaking department of Government, and must, upon their own responsibility, determine whether, in any particular case, these limits have been passed. 'To what purpose,' it was said in Marbury v. Madison, 1 Cranch 137, 5 U. S. 167, 'are powers limited, and to what purpose is that limitation committed to writing if these limits may, at any time, be passed by those intended to be restrained? The distinction between a Government with limited and unlimited powers is abolished if those limits do not confine the persons on whom they are imposed and if acts prohibited and acts allowed are of equal obligation.' The courts are not bound by mere forms, nor are they to be misled by mere pretenses. They are at liberty, indeed, are under a solemn duty, to look at the substance of things whenever they enter upon the inquiry whether the legislature has transcended the limits of its authority. If, therefore, a statute purporting to have been enacted to protect the public health, the public morals, or the public safety has no real or substantial relation to those objects, or is a palpable invasion of rights secured by the fundamental law, it is the duty of the courts to so adjudge, and thereby give effect to the Constitution" (123 U.S., p. 661). En casos anteriores, Marbury es citado por la Corte solamente en el contexto de cuestiones jurisdiccionales o de casos relacionados con un writ of mandamus". De hecho, como ya dije, Warren (1922, pp. 231 y ss.) lo denomina como "The Mandamus Case". 
un caso más en una saga que empieza antes de la sanción de la Constitución en 1787 y se mantiene a partir de Hayburn. ${ }^{162}$ Y en algunas publicaciones directamente ni se lo menciona. ${ }^{163}$ Además, hasta 1894, el ejercicio del deber de los jueces de controlar las leyes federales que contradijeran la Constitución en los casos que tuvieran que decidir no había generado mayores debates públicos. Sin embargo, el año 1895 marca un cambio rotundo a partir del caso Pollock, ${ }^{164}$ una decisión tomada por una mayoría de cinco votos contra cuatro. En esa célebre decisión, esta vez citando de forma directa a Marbury v. Madison en relación con el poder de los jueces de invalidar una ley, ${ }^{165}$ la Suprema Corte declaró inconstitucional una ley federal que había establecido el impuesto a las ganancias. ${ }^{166}$ A partir de allí, se produjo un intenso debate acerca de lo que hoy conocemos como la judicial review y el rol de los jueces en el sistema constitucional estadounidense. ${ }^{167}$ Es en el marco de las polémicas suscitadas en relación con el caso Pollock que comenzó a tomar cuerpo el mito de Marbury.

Uno de los principales impulsores del mito fue el gobernador del estado de Oregon, Sylvester Pennoyer. ${ }^{168}$ Cuando todavía era gobernador, publicó en la American Law Review una crítica inusualmente dura contra la sentencia de la Suprema Corte (Pennoyer, 1895, p. 550). Allí denunció la existencia de una oligarquía judicial, planteó la necesidad de remover a los jueces a través del impeachment y afirmó que la Corte había usurpado una facultad legislativa que la Constitución no le había otorgado (Pennoyer, 1895, pp. 556-558). Un año des-

162 Entre otros, J. H. M. (1870, p. 585), Elliot (1890, p. 224), etcétera.

163 Ver, entre otros, el sorprendente libro de Spooner (1845), Kent, (1872), etc. Resulta sugestivo también el libro de García (1863). Manuel Rafael García fue comisionado por el Gobierno argentino para estudiar el sistema judicial estadounidense. En este libro, que fue considerado como un antecedente de la todavía vigente Ley 48 en la República Argentina, desarrolla el estudio que hizo en los Estados Unidos y, al momento de referirse al control judicial de constitucionalidad, cita el caso Hayburn (García, 1863, pp. 10-11), pero no Marbury v. Madison.

164 Pollock v. Farmers' Loan EF Trust Company, 157 U.S. 429 (1895).

165 "Since the opinion in Marbury v. Madison, 1 Cranch 137, 5 U. S. 177, was delivered, it has not been doubted that it is within judicial competency, by express provisions of the Constitution or by necessary inference and implication, to determine whether a given law of the United States is or is not made in pursuance of the Constitution, and to hold it valid or void accordingly" (157 U.S., p. 554).

166 El impuesto a las ganancias sería finalmente convalidado a través de la Enmienda XVI en 1913. El fallo Pollock sería dejado sin efecto más de cien años después de dictado en South Carolina v. Baker, 485 U.S. 505 (1988).

167 Ver, entre otros, Edwards (1896, p. 183); Fowler (1895, p. 711); Lewis (1895, p. 189); Taft (1895, p. 576); Parker (1896, p. 357); Tiedeman (1895, p. 72); etc.

168 Pennoyer había perdido una propiedad unos años antes en un caso en la Suprema Corte (ver Pennoyer v. Neff, 95 U.S. 714 [1878]). 
pués, en 1896, insistió con la supuesta "usurpación” pergeñada por la sofistería de Marshall y acusó a la Suprema Corte de haberse apropiado una facultad que no tenía (Pennoyer, 1896, p. 188). Pennoyer, líder del entonces Partido Populista, usó esa crítica a Marbury como plataforma para acusar a la Suprema Corte de defender los intereses de las corporaciones y de los ricos y de dar la espalda a medidas que tenían fuerte apoyo popular, como, por ejemplo, la ley que creaba el impuesto a las ganancias (Pennoyer, 1896, pp. 201-202).

Si bien los ataques de Pennoyer fueron descalificados ya en la misma época como "absurdos e indefendibles" (Carson, 1895, p. 796), lo cierto es que la insistencia en ese tipo de tesis fue ganando terreno durante las primeras décadas del siglo XX. ${ }^{169}$ En un escenario de gran activismo judicial, ${ }^{170}$ el control judicial de constitucionalidad seguiría siendo duramente cuestionado por quienes apoyaban las transformaciones que se querían lograr a través de medidas legislativas, tanto a nivel estatal como federal. ${ }^{171}$ Así, no solo el Poder Judicial y, en especial, la Suprema Corte, sino también la propia Constitución ${ }^{172}$ serían sometidos a una crítica sistemática en esos años, ${ }^{173}$ especialmente desde la escuela del realismo y del movimiento político e intelectual conocido como "the American Progressivism". ${ }^{174}$ Esas críticas, a su vez, se dieron en medio de una incipiente discusión, entre muchas otras cosas, ${ }^{175}$ acerca del conflicto entre "in-

169 Cfr. Watson (2009).

170 No uso el término "activismo" de forma peyorativa. Coincido con Barnett (2007, pp. 493-496) que, en realidad, se trata de un "cliché" constitucional.

171 La actuación de la Suprema Corte en esos años ha sido reseñada de forma magistral en castellano por Bianchi (2005).

172 La crítica más influyente de la época fue la de Beard (1913). A través de una interpretación marxista de la historia, Beard acusó a los Founding Fathers de haber impuesto una constitución ideada meramente para proteger sus intereses económicos. La tesis de Beard fue demolida años después en un libro no tan conocido, cuya lectura recomiendo: Charles Beard and the Constitution. A critical Analysis of "An Economic Interpretation of the Constitution" (Brown, 1956).

173 El estudio más completo al respecto es el de Ross (1994).

174 Al respecto, ver Eisench (2006). Las figuras más relevantes de ese amplio movimiento reformista fueron Oliver Wendell Holmes, Woodrow Wilson, Charles Beard, Karl Llewellyn, Max Lerner, Edward Corwin, John Dewey, Roscoe Pound, Benjamin Cardozo y Louis D. Brandeis.

175 Una de las discusiones importantes giró en torno a la interpretación de la Constitución por parte de los jueces. Aunque excede el alcance de este trabajo, cito la opinión de Tiedeman a modo ilustrativo: "The American people are not, and should not be, ruled by the commands of dead men, however distinguished they may be, and however much they and their political wisdom challenge and deserve our veneration. In so far as their ideas of political wisdom are embodied in the written word of the Constitution, public opinion now requires them to be generally followed and obeyed by the courts and legislatures, and to that extent do the courts recognize the constitutional limitations upon the powers of the different branches of the government. But when the written word of the Constitution 
dividualismo y socialismo" (Tiedeman, 1895, p. 82), de una revisión radical del concepto de libertad (Smith, 2013, pp. 7-25), de un cuestionamiento abierto a la idea de que el sistema constitucional estadounidense había instaurado un gobierno de leyes y no de hombres ${ }^{176} \mathrm{y}$, en definitiva, de una discusión fundamental acerca de cuál era el valor fundamental que debía proteger la Constitución: la libertad o la democracia (Horwitz, 1993, p. 30).

En ese contexto, es en 1909 que aparece por primera vez la expresión judicial review como sinónimo del poder (y no del deber) de los jueces de declarar la in-

hampers the actions of the government in a way that public opinion considers so injurious that they require the written word of the Constitution to be ignored, the courts justly obey the popular mandate, at the same time keeping up a show of obedience to the written word by the skillful use of legal fictions" (Tiedeman, 1895, p. 82). Tiedeman anticipó ya en 1895 las discusiones que se darían en los Estados Unidos a lo largo del siglo XX y que aún hoy se mantienen vigentes en materia de interpretación constitucional. Para un análisis de las discusiones y cambios que se produjeron en este período es indispensable ver Gillman (1997).

176 Esa idea política condensa lo que se conoce en el mundo anglosajón como Rule of Law. Si bien la frase "a government of laws, and not of men" podría remontarse hasta Aristóteles ("ies más ventajoso ser gobernados por el mejor de los hombres o por las mejores leyes?" [Aristóteles, 1885, p. 98]), lo cierto es que en el mundo anglosajón fue popularizada a través de James Harrington. En su influyente Oceana, en 1656, defendió la utopía de un "Empire of Laws, and not of Men" (Harrington, 1700, p. 37). En 1742, David Hume (1882) quiso aplicarla al gobierno monárquico: "But though all kinds of government be improved in modern times, yet monarchical government seems to have made the greatest advances towards perfection. It may now be affirmed of civilized monarchies, what was formerly said of republics alone, that they are a government of Laws, not of Men. They are found susceptible of order, method, and constancy, to a surprising degree” (p. 161). Esa relación que Hume marcaba entre monarquía civilizada y legalidad fue cuestionada abiertamente en 1776 por Thomas Paine (2005) en su célebre Common Sense: "But where, say some, is the King of America? [...] [I]n America the law is king" (p. 44). Más allá de este contrapunto, Harrington fue el vehículo a través del cual la frase llegó a John Adams, quien redactó la Constitución de Massachusetts de 1780, cuyo artículo 30 dice: "In the government of this commonwealth, the legislative department shall never exercise the executive and judicial powers, or either of them; the executive shall never exercise the legislative and judicial powers, or either of them; the judicial shall never exercise the legislative and executive powers, or either of them; to the end it may be a government of laws, and not of men" (Kurland y Lerner, 1987, pp. 13-14). De ahí, finalmente, la tomó John Marshall y la citó en Marbury v. Madison: "The Government of the United States has been emphatically termed a government of laws, and not of men. It will certainly cease to deserve this high appellation if the laws furnish no remedy for the violation of a vested legal right" (5 U.S. (1 Cranch), p. 163). A pesar del pedigrí de la idea (y de la frase), comenzó a ser fuertemente cuestionada a comienzos del siglo XX en los Estados Unidos. Primero pretendió haber sido superada: "The history of the United States, since the adoption of the constitution, covers less than 128 years. Yet in that short period the American ideal of government has been greatly modified. At first our ideal was expressed as 'A government of laws and not of men.' Then it became 'A government of the people, by the people and for the people.' Now it is 'Democracy and social justice" (Brandeis, 1916, p. 461). Luego, fue frontalmente atacada por los realistas por tratarse de un dogma absurdo, con expresiones como esta: "Let us banish from our professional tenets the absurd dogma 'a government of laws and not of men' [...] there is no place for it in legal science" cfr. Kennedy (1945, p. 24). 
constitucionalidad de una ley en los Estados Unidos. ${ }^{177}$ El creador de esa expresión fue Edward Samuel Corwin (1909, pp. 660 y 670), politólogo de la Universidad de Princeton y presidente de la American Political Science Association. ${ }^{178}$ Corwin tuvo una gran influencia en diversos campos, especialmente en su defensa de la idea de la existencia de una "constitución viviente"179 y sus constantes cuestionamientos al control judicial de constitucionalidad. ${ }^{180}$ De hecho, fue uno de los grandes impulsores del mito de Marbury. ${ }^{181}$ Por eso, no es casual que la historiadora Mary Sarah Bilder (2010) concluya que "Marbury no inventó la judicial review. Esa hazaña le corresponde a Corwin" (p. 1144).

Más allá de la influencia de Corwin, lo cierto es que quienes rechazaban esa judicial review continuaban denunciándola, de forma abierta o subrepticia, como una usurpación. ${ }^{182} \mathrm{O}$ la cuestionaban por obsoleta ya que, en teoría, el surgimiento de los entes administrativos empezaba a desplazar a los tribunales como mediadores entre el Estado y el individuo. ${ }^{183} \mathrm{O}$, peor aún, al igual que había hecho Pennoyer, la seguían atacando por ser un ejemplo del comportamiento de una oligarquía judicial que defendía los intereses de empresarios inescrupulosos. ${ }^{184}$

Como explica Clinton (1989, p. 18), dentro de esta estrategia de cuestionamientos a los tribunales federales desplegada por los críticos reformistas durante ese período, uno de sus puntos de ataque fue Marbury v. Madison. Es en este contexto que lo que había comenzado como una crítica aislada después de la controvertida decisión en el caso Pollock termina de tomar cuerpo y asentarse a través de las sucesivas críticas y réplicas. Es también en ese ambiente

177 Cfr. Bilder (2010, p. 1131).

178 Corwin ingresó a Princeton invitado por Woodrow Wilson en 1905.

179 Cfr. Gillman (1997, p. 235).

180 Entre muchos otros, destaco: Corwin (1906, p. 616; 1911a, p. 102; 1911b, p. 283), etc. Corwin (1911a) afirma erróneamente que "the establishment of judicial review gave the constitution the character of law" (p. 110) y se refiere al control judicial de constitucionalidad como "a retarding agency" (p. 113).

181 Además de criticar la judicial review por esconder siempre el ejercicio de algún tipo de prejuicio por parte de los jueces, Corwin (1909, p. 625) afirma por primera vez que Marbury fue el primer caso y Dred Scott el segundo en el que la Corte determinó los méritos constitucionales de una ley del Congreso. Corwin (1911b) también fue el creador de la leyenda acerca del carácter de maniobra política magistral de la decisión: "Regarded merely as a judicial decision, the decision of Marbury v. Madison must be considered as most extraordinary, but regarded as a political pamphlet designed to irritate an enemy to the very limit of endurance, it must be considered a huge success" (p. 292).

182 Ver, entre muchos otros, Tricket (1906, p. 356), Boudin (1911, p. 238), etcétera.

183 Ver, por ejemplo, Corwin (1913, p. 572).

184 Ver, por ejemplo, Lerner (1933, p. 668). 
de constantes críticas a Marbury v. Madison que el senador Albert Beveridge (1916) publica en cuatro tomos la biografía más completa sobre Marshall, que colaboraría aún más para agigantar su figura. ${ }^{185}$ Así es que la leyenda acerca de la supuesta genialidad política de Marshall que, a través de la célebre sentencia de 1803, habría logrado que la Suprema Corte se autoasignara la judicial review como forma de salir de la incómoda situación en la que Jefferson la había puesto se convierte en parte de la historia oficial. ${ }^{186}$

Si bien hubo voces que continuaron defendiendo la versión tradicional del rol de los jueces y del deber que tenían de dejar sin efecto las leyes que contradijeran la Constitución, ${ }^{187}$ lo cierto es que luego de la reconfiguración total de la Suprema Corte durante las cuatro presidencias consecutivas de Franklin Delano Roosevelt, ${ }^{188}$ esas voces fueron apagándose poco a poco. A su vez, el control judicial sufriría una drástica mutación para intentar reconciliarlo con el sistema mayoritario. ${ }^{189}$ Como contrapartida, el mito de Marbury sería repetido de forma mecánica durante gran parte del siglo XX tanto por defensores como por detractores de la judicial review en cualquiera de sus variantes.

\section{La revisión de la historia oficial}

La revisión de la historia oficial no se concentró al principio en intentar corregir alguno de los aspectos del mito de Marbury ni en poner en su justo lugar la importancia del caso en relación con el origen del control judicial de constitucionalidad. Por el contrario, comenzó de forma genérica en la década de $1960^{190}$ a través del cuestionamiento de algunas exageraciones impuestas por el progresismo en la historiografía constitucional. ${ }^{191}$ White (2010, p. 1174), uno de

185 El último tomo se publicaría en 1919.

186 Por todos, ver Lerner (1939, p. 396).

187 Burr (1912, p. 624), Carson (1912, p. 687), Lanier (1923, p. 577), etcétera.

188 Contrariamente a lo que se suele afirmar, Roosevelt tenía previsto desde por lo menos 1932, es decir, antes de asumir su primera presidencia, desarrollar un plan para limitar el accionar de la Suprema Corte, incluida la posibilidad de un "court-packing" plan (cfr. McKenna, 2002, p. xxi y pp. 158 y ss.). A pesar de su infructuoso embate para modificar la composición del número de integrantes de la Suprema Corte, Roosevelt terminaría designando, en un lapso de apenas seis años (entre 1937 y 1943) la friolera de nueve Justices en la Suprema Corte: Hugo L. Black, Stanley Forman Reed, Felix Frankfurter, William O. Douglas, Frank Murphy, James F. Byrnes, Harlan Frisk Stone, Robert H. Jackson y Wiley Blount Rutledge. Su influencia sería decisiva y se extendería por décadas.

189 Al respecto, ver García-Mansilla (2009, pp. 303 y ss.).

190 Ver, por ejemplo, Jones (1967, p. 751).

191 Uso el término "progresismo" no en sentido moderno, sino para reflejar lo que en los Estados Unidos 
los historiadores del derecho más importantes de los Estados Unidos, explica que el progresismo en la historiografía jurídica tenía como premisas centrales las siguientes: una lectura de la historia norteamericana como una lucha de clases e intereses, la consideración de la labor del Poder Judicial como algo meramente instrumental e ideológico y la idea de que para poder entender las sentencias hay que aplicar un análisis del comportamiento de los jueces (exagerando, ver qué desayunaron para entender sus fallos).

Ese tipo de historiografía no solo había impulsado la consolidación del mito de Marbury, sino otras relacionadas, como por ejemplo la que se refiere al origen del conflicto entre la Suprema Corte y el New Deal. ${ }^{192}$ Pero fue sistemáticamente revisada y cuestionada en los Estados Unidos por varios autores y sobre diversos períodos históricos a partir de la década de 1980, especialmente en lo que se refiere al origen del control judicial de constitucionalidad. Recurro nuevamente a White (2010) para comprender el impacto del revisionismo de los últimos años:

La ortodoxia historiográfica tiene típicamente una duración muy extensa. Ha llevado casi un siglo para que la ortodoxia del progresismo se desmorone. Pero se está desmoronando ciertamente -tal vez al borde de la desintegración- en la historia legal y constitucional estadounidense. (p. 1151)

En lo que se refiere concretamente a los orígenes de la judicial review, la obra de muchos de los autores citados en este trabajo, como William M. Treanor, Keith E. Whittington, Mary S. Bilder, Mark D. Hall, Kermit L. Hall, William R. Casto, Scott D. Gerber, y, fundamentalmente, Philip Hamburger, ha sido decisiva para corregir los errores históricos de la leyenda oficial en torno al mito de Marbury. El esfuerzo de estos autores no solo significó el estudio completo de la actuación de la Suprema Corte anterior al ingreso de John Marshall en $1801^{193}$ - a la que la historiografía constitucional oficial en general menospreciaba por considerarla de escasa importancia- ${ }^{194}$ sino también la elaboración exhaustiva de la biografía de sus integrantes. ${ }^{195}$ A su vez, el trabajo de Maeva

se conoce como "the progressive legal and constitutional historiography".

192 En este punto también hubo una revisión profunda de la historia oficial en los últimos años. Entre muchos otros, ver Cushman (1998).

193 Al respecto, ver Gerber (2018, p. 27).

194 Ver, por ejemplo, Schwartz (1993, p. 33).

195 Algunas de esas biografías, citadas en este trabajo, se publicaron en conjunto: Gerber (1998). Otras fueron publicadas de forma individual. 
Macus y James Perry (1985), con su historia de la Suprema Corte entre 1789 y 1800 documentada en varios tomos, ${ }^{196}$ y el estudio exhaustivo de Stephen Presser sobre la figura de Samuel Chase (2009) contribuyeron también para poder contar con todo el material disponible para el análisis del período indicado. ${ }^{197}$

El bicentenario de Marbury v. Madison en 2003 representó, además, una oportunidad para revisar nuevamente la importancia de la sentencia en la historia constitucional de los Estados Unidos. Como explica Bilder (2010), la mayoría de los nuevos trabajos académicos publicados acerca de esta célebre sentencia sugirieron que no fue tan determinante y su significado ha sido puesto en duda por muchos de ellos. ${ }^{198}$

En ese marco, varios de los autores mencionados encararon un trabajo sistemático para poder explicar los orígenes del control judicial de constitucionalidad. El análisis de cada una de las teorías que surgieron en los últimos años requeriría un nuevo trabajo de mi parte. Sin perjuicio de ello, puedo mencionar: las que van desde explicar el origen de la judicial review como una práctica judicial continua, que comienza con los numerosos casos de revisión de leyes locales por parte de tribunales de diversos estados previos a 1787 (Treanor, 2005, p. 455); como la expresión de una teoría política que se expresa en la importancia de la conexión inescindible entre la judicial review y el surgimiento de la independencia del Poder Judicial entre los siglos XVII y XVIII (Gerber, 2011); como una práctica originada en el derecho corporativo inglés que exigía la anulación de normas de diversa jerarquía (Bilder, 2006, p. 502); o hasta la que encuentra el origen del control de constitucionalidad en el deber que tenían los jueces de resolver los casos aplicando el derecho vigente, incluida la Constitución, también en la Inglaterra medieval (Hamburger, 2008).

Estas teorías modernas tienen muy sólidos fundamentos en cada caso y son compatibles entre sí. De hecho, en muchos casos se complementan. Sin perjuicio de ello, creo que la más convincente es la de Philip Hamburger. En su demoledor Law and Judicial Duty (2008) demuestra que el origen de la judicial review tiene lugar en la Inglaterra medieval, cuyos jueces tenían el deber de resolver los casos aplicando el derecho del reino. ${ }^{199}$ Dado que la constitución

196 A la fecha, se han publicado siete tomos más, el último de ellos en 2007. Lamentablemente, no tuve acceso a esta obra al momento de escribir este trabajo.

197 Ver, entre otros, Presser y Hurley (1984, p. 771) y Presser (2009, p. 349).

198 Cfr. Bilder (2010, p. 1142).

199 Hamburger no otorga mayor relevancia al famoso dictum del juez Edward Coke en el caso Bonham, al que considera un caso de "equitable interpretation" (Cfr. Hamburger, 2008, pp. 622-630). Sin 
era la parte de mayor jerarquía de ese derecho, los jueces en el cumplimiento de su deber judicial tenían que declarar la inconstitucionalidad y la nulidad de costumbres, normas y actos de gobierno (Hamburger, 2008, pp. 101 y ss.). Ese deber, a su vez, se reflejaba en el juramento que prestaban los jueces al momento de asumir el cargo (pp. 106 y ss.). Durante una evolución que llevó cientos de años y que incluyó debates riquísimos acerca de, por ejemplo, la discrecionalidad de los jueces ya en el siglo XVI (pp. 132 y ss.), la función judicial fue concebida incluyendo ese deber como inherente al cargo de juez. Desde ese paradigma del deber judicial no existe un poder especial en cabeza de los jueces para revisar la constitucionalidad de actos de los otros poderes, sino que la judicial review es simplemente un aspecto más del deber general que tienen que cumplir habitualmente a la hora de decidir casos y controversias (Hamburger, 2010, p. 1162). Y esa misma concepción de la función judicial fue adoptada en los Estados Unidos, pero con diferencias fundamentales, incluyendo el desplazamiento de la soberanía desde el Parlamento a la Constitución. ${ }^{200}$ Por supuesto, este origen y desarrollo histórico de la judicial review contrasta notablemente con el supuestamente heroico en manos de Marshall. Por eso, se ha dicho con razón que se trata de una teoría que nos muestra sencillamente "la grandeza de lo ordinario" (Althouse, 2010, p. 1123).

Cualquiera sea la opinión que pueda tenerse sobre cuál es "la" teoría que explica mejor el origen de la judicial review, tema ajeno a este trabajo, lo cierto es que esta nueva escuela historiográfica ha desterrado por completo todos los errores históricos que sustentan lo que he denominado "el mito de Marbury", incluida la leyenda acerca del nacimiento del control judicial de constitucionalidad en Marbury v. Madison a través de la intervención proverbial y exclusiva de la figura de John Marshall.

perjuicio de ello, sobre los pormenores del caso Bonham sugiero ver el excelente trabajo de Rey Martínez (2007, p. 163).

200 Obviamente, los jueces ingleses no podían declarar la inconstitucionalidad de las leyes del Parlamento, pero esa imposibilidad no tenía que ver con la falta de poder de los jueces ni con la soberanía del Parlamento. Ese obstáculo, en realidad, tenía que ver con el estatus judicial que tenía el Parlamento británico, que era la máxima jerarquía judicial. Bajo esa perspectiva, el resto de los tribunales eran considerados de rango inferior y, obviamente, no podían dejar sin efecto decisiones de la corte superior (Cfr. Hamburger, 2008, pp. 239 y ss.). Ese y otros obstáculos, como la falta de una constitución escrita, no estaban presentes ni podían condicionar a los jueces de los Estados Unidos, que daban por sentado el deber judicial de invalidar los actos de gobierno que contradijeran la constitución (pp. 398 y ss.). 


\section{5. ¿Por qué es importante corregir el mito de Marbury?}

Llegados a este punto, el lector podría plantear que todo lo expuesto es un mero ejercicio de revisión académica e histórica que no tiene otro sentido que corregir por corregir. $\mathrm{O}$, peor aún, corregir lo que ya estaba corregido (aunque no tan difundido). Sin embargo, ese planteo sería un grave error. Rectificar de raíz el mito de Marbury es importante por varias razones.

En primer lugar, porque es evidente que el mito no se corresponde con los hechos históricos. No desconozco que la revisión de la historia es muchas veces una tarea compleja y no exenta de errores, y no pretendo criticar a quienes se guiaron por la corriente considerada ortodoxa durante tantos años, pero es obvio que sacralizar una versión distorsionada de la historia inevitablemente contamina el análisis que se hace a partir de ella. Además, la revisión de la historia oficial basada en nuevas evidencias, o nuevos análisis de evidencias existentes, ayuda a comprender mejor a instituciones centenarias con las que todavía convivimos. Y no hace falta ser historiador para darse cuenta de que la historia tiene un papel relevante para el derecho constitucional y corresponde hacerla correctamente. ${ }^{201}$

En segundo lugar, y más importante aún, el mito de Marbury perpetúa la creencia de que la principal atribución de los jueces en un sistema constitucional de cuño estadounidense fue autoadjudicada en medio de un conflicto político, ${ }^{202}$ es decir, una facultad inventada por ellos mismos y bendecida solamente por el paso del tiempo y la conformidad tácita de los otros dos poderes. En definitiva, que se impuso desde fuera de la constitución. Así, cada vez que se enseña el mito de Marbury y su supuesta creación del control judicial de constitucionalidad, en lugar de fortalecer el Estado de derecho se lo socava de forma involuntaria. Se enseña que los jueces no están limitados por la norma más importante del derecho vigente y a la que deben su autoridad para juzgar: la constitución. Se enseña que la constitución es el barro que los jueces moldean a su gusto y preferencia, como decía Jefferson. ${ }^{203} \mathrm{Y}$ se olvida también que

201 Sobre este punto, ver Belz (1994, p. 45).

202 A modo de ejemplo, obsérvese la elocuente apreciación que hace Rosen (2007) acerca del genio político de Marshall para lidiar con el seguro incumplimiento de Jefferson en caso de que la Corte ordenara la designación de Marbury: "Marshall extricated himself from this exquisite dilemma with an act of judicial jujitsu that, two centuries later, still inspires awe for its craftiness" (p. 30).

203 Carta de Thomas Jefferson a Spencer Roane del 6 de septiembre de 1819: "[T]he Constitution, on this hypothesis, is a mere thing of wax in the hands of the judiciary which they may twist and shape into any form they please" (The Papers of Thomas Jefferson. Retirement Series, tomo 15 (septiembre de 1819 a mayo de 1820), 2018, Nueva Jersey: Princeton University Press, p. 17). 
la constitución, como norma de máxima jerarquía del orden jurídico, limita no solo al Ejecutivo y al Congreso, sino principalmente a los jueces cuyo rol es decidir casos y controversias de conformidad con lo previsto en la constitución. ${ }^{204}$

En un simposio académico organizado por The George Washington Law Review en 2009, el Justice Anthony Kennedy sostuvo que si fuera cierto que la judicial review había sido inventada por la Suprema Corte, entonces los jueces "podrían hacer lo que se les dé la gana” (Althouse, 2010, p. 1127). Aun cuando suene exagerado, lo cierto es que parece lógico que si aceptamos, aunque más no sea prima facie, la tesis que sostiene que los jueces se autoadjudicaron su principal atribución, entonces resultaría razonable que ellos mismos puedan decidir cuándo ejercerla o hasta dónde pueden hacerlo. De hecho, esta es la premisa de la que generalmente se parte a la hora de analizar las distintas modalidades del control judicial de constitucionalidad, la aplicación de la presunción de constitucionalidad o no en diversas circunstancias, la idea de la existencia de "libertades preferidas", etc. Se corre así el peligro de que la constitución se convierta en un acordeón que se estira o se contrae dependiendo del contenido que se le quiera extraer o de la visión que se tenga de ella.

En tercer lugar, el mito de la creación de la judicial review en Marbury presupone de alguna forma que la constitución es lo que los jueces dicen que es. ${ }^{205}$ No me refiero a la autoridad que tienen los jueces de la Suprema Corte de decidir un caso concreto como máxima instancia judicial, sino más bien a la idea de que la interpretación que se hace de la constitución tenga el mismo valor que ella por fuera de esa decisión en particular. ${ }^{206} \mathrm{Y}$ eso no es lo que surge de Marbury v. Madison.

El punto anterior me lleva, en cuarto lugar, a observar que la revisión del mito de Marbury es importante para distinguir conceptualmente entre judicial review y judicial supremacy: una cosa es el deber de los jueces de declarar inconstitucional una ley del Congreso que contradiga la constitución en el marco de

204 A modo de ejemplo, el artículo 112 de la Constitución argentina dispone que los jueces de la Suprema Corte deben administrar justicia "bien y legalmente, y en conformidad a lo que prescribe la Constitución".

205 Charles Evan Hughes, siendo gobernador del estado de Nueva York, dijo en 1907: "We are under a Constitution but the Constitution is what the judges say it is", ver Leahy (1989, p. 491).

206 Si bien la cuestión excede largamente los límites de este trabajo, creo que si esa tesis fuera correcta, no tendríamos punto de apoyo en la Constitución para criticar los fallos de la Corte, ya que, por definición, serían siempre correctos. Al respecto, ver Baude (2019, p. 260). En contra, ver Alexander y Schauer (2000, p. 455). La defensa de Alexander y Schauer no es en términos históricos, sino filosóficos. 
un caso concreto y otra muy distinta es que la Suprema Corte tenga la última palabra en materia de interpretación de la constitución con efectos fuera de ese caso. Es evidente que judicial review y judicial supremacy son claramente distinguibles a nivel conceptual y que requieren argumentos propios en cada caso para ser defendidas. Sin embargo, ambas cuestiones se atribuyen erróneamente a Marbury v. Madison y se suelen confundir. Como explica Barnett (2004), la confusión surge cuando se ignora que la negación judicial de una norma por su eventual inconstitucionalidad no puede ser asimilada a la legislación ("judicial negation is not legislation"). ${ }^{207}$

Lo cierto es que Marbury tampoco establece la judicial supremacy ni pretende hacerlo. ${ }^{208}$ Ninguno de los argumentos expuestos por Marshall en esa sentencia permite explicar por qué la Suprema Corte tiene que ser el "intérprete final" de la Constitución con un alcance que exceda el marco del asunto decidido. ${ }^{209}$ Y una cosa es que lo sea en el marco de ese caso concreto, con la consiguiente obligación para el Poder Ejecutivo y el Legislativo de acatar su decisión, y otra muy distinta es que ese carácter implique que todos los poderes están obligados a seguir su interpretación de modo general fuera de ese asunto. Ese último carácter fue expuesto por primera vez en Cooper v. Aaron ${ }^{210}$ en 1958, distorsionando lo decidido en Marbury, ${ }^{211}$ y posteriormente fue llevado al paroxismo en Dickerson v. United States ${ }^{212}$ en el año 2000.

Finalmente, el quinto y último punto que quiero destacar es que en el

207 Cfr. Barnett (2004, p. 133).

208 Cfr. Garay (2009, p. 132).

209 A través de un análisis minucioso de la sentencia de Marshall, Paulsen (2003) concluye que el razonamiento de Marbury y la moderna práctica constitucional son irreconciliables y que la lógica de esta sentencia contradice cualquier planteo acerca de la supremacía judicial (pp. 2718 y ss.).

210 Cooper v. Aaron, 358 U.S. 1 (1958). Al respecto, la Corte sostuvo: "In 1803, Chief Justice Marshall, speaking for a unanimous Court, referring to the Constitution as "the fundamental and paramount law of the nation," declared in the notable case of Marbury v. Madison, 1 Cranch 137, 5 U. S. 177, that "It is emphatically the province and duty of the judicial department to say what the law is." This decision declared the basic principle that the federal judiciary is supreme in the exposition of the law of the Constitution, and that principle has ever since been respected by this Court and the Country as a permanent and indispensable feature of our constitutional system" (358 U.S., p. 18).

211 Al respecto, ver Engdahl (1992, p. 279).

212 Dickerson v. United States, 530 U.S. 428 (2000). En el voto de la mayoría, el Chief Justice Rehnquist sostuvo que Miranda v. Arizona era una "decisión constitucional" y que el Congreso no podía modificar las célebres reglas establecidas en ese caso: "In Miranda v. Arizona, 384 U.S. 436 (1966), we held that certain warnings must be given before a suspect's statement made during custodial interrogation [...]. Congress retains the ultimate authority to modify or set aside any judicially created rules of evidence and procedure that are not required by the Constitution. [...] But Congress may not legislatively supersede our decisions interpreting and applying the Constitution” (530 U.S., p. 431 y p. 437). 
ámbito de los países que son parte de la Convención Americana de Derechos Humanos (CADH), la revisión del mito de Marbury permite poner en contexto crítico la creación ex nihilo del llamado "control de convencionalidad" por parte de la Corte Interamericana de Derechos Humanos (Corte IDH). En 2006, en el caso Almonacid Arellano, la Corte IDH dispuso la obligación de los jueces locales de ejercer el "control de convencionalidad" sobre las normas jurídicas internas, así como de la pretendida obligación de seguir sus fallos por tratarse del "intérprete final" de la CADH. ${ }^{213}$

Ese control de convencionalidad pretende someter a través de los jueces locales a todo el derecho interno, incluida la propia constitución de cada país, a un examen de compatibilidad con la CADH. Y dado que, además, se pretende que ese examen incluya no solo las disposiciones de la $\mathrm{CADH}$, sino también la jurisprudencia de la Corte IDH, entonces estamos ante un intento de mutación radical que contradice frontalmente los sistemas de constitución rígida. ${ }^{214}$ Se trata, esto es obvio, de un problema de enorme magnitud: no puede escapar a nadie que la idea de un control de convencionalidad que incluya a la propia constitución no solo viola los mecanismos de reforma constitucional en un sistema rígido, sino que introduce un elemento de enorme inseguridad jurídica al permitir que cualquier juez local deje sin efecto a la constitución a la que, paradójicamente, deben su designación y autoridad para juzgar. Sin embargo, bajo el paradigma del mito de Marbury parecería no haber mayor conflicto ya que estaríamos nuevamente ante un caso de creación, invención o autoadjudicación de atribuciones, pero a través de una sentencia internacional. No creo que sea casual que frecuentemente se cite a Marbury v. Madison en trabajos académicos referidos al control de convencionalidad ${ }^{215}$ y que, en algunos casos, se pretenda trazar un paralelismo entre ambas sentencias. ${ }^{216}$ De forma consciente o no, el planteo parece ser: si lo hizo John Marshall, ¿por qué no podrían hacerlo los jueces de la Corte IDH?

213 Corte IDH, "Caso Almonacid Arellano y otros vs. Chile", Excepciones Preliminares, Fondo, Reparaciones y Costas, sentencia del 26 de septiembre de 2006, Serie C, № 154, párr. 124 (“[E]l Poder Judicial debe ejercer una especie de 'control de convencionalidad' entre las normas jurídicas internas que aplican en los casos concretos y la Convención Americana sobre Derechos Humanos. En esta tarea, el Poder Judicial debe tener en cuenta no solamente el tratado, sino también la interpretación que del mismo ha hecho la Corte Interamericana, intérprete última de la Convención Americana").

214 He analizado la relación compleja entre el derecho internacional y el derecho interno en el contexto argentino en García-Mansilla (2013, pp. 356-374) y (2018, pp. 16-43), a los que remito. Sugiero también leer el trabajo de Ramírez Calvo (1995, p. 773), que sigue siendo de consulta obligada.

215 Ver, por ejemplo, Ghisio y Junco (2019, p. 78).

216 "La jurisprudencia de la CIDH a partir del caso 'Almonacid Arellano y otros v. Chile' de 2006, sobre el 'control de convencionalidad' a cargo de los jueces y tribunales del Poder Judicial de los 


\section{Conclusión}

Nada de lo expuesto en este trabajo implica un demérito acerca de la figura de John Marshall. El planteo acerca de que no debe ser considerado como "el padre del control judicial de constitucionalidad" no desmerece en nada su actuación pública como juez ni la importancia de su estudio. Fue, sin lugar a dudas, un Chief Justice brillante que ayudó decisivamente a solidificar una institución tan trascendente como la Suprema Corte de los Estados Unidos y también a la propia Constitución de 1787. La lectura de su vida, de su trayectoria pública y, fundamentalmente, de sus fallos deja y dejará siempre enormes enseñanzas.

Tampoco debe leerse como un intento de desmerecer la importancia de la decisión en Marbury v. Madison, sino de ubicarla en una adecuada perspectiva histórica. ${ }^{217}$ Sí quiero llamar la atención acerca de que el control judicial de constitucionalidad no fue una creación pretoriana como pretende el mito de Marbury, y también advertir que la judicial review era considerada como un deber inherente a la función judicial prevista en la Constitución de los Estados Unidos y así había sido concebida mucho antes de $1803 .{ }^{218}$

Finalmente, como ya dije, no pretendo criticar a quienes, basados en fuentes bibliográficas norteamericanas, repiten una historia que no se cuestionó durante mucho tiempo en su país de origen. Por el contrario, creo que para el conocimiento cabal del derecho constitucional es indispensable el seguimiento de los debates académicos que existen en el mundo anglosajón, especialmente en los Estados Unidos. No es por un "afán norteamericanista”, como me acusaron alguna vez junto con Ricardo Ramírez Calvo, sino por la enorme riqueza

Estados Partes, puede considerarse de tanta importancia como el caso 'Marbury v. Madison' de la Suprema Corte de los EE.UU., de 1803, dado que consagra una especie de 'supranacionalidad' en materia de derechos humanos, aun sin norma expresa que así lo habilite" (Pérez Manrique, p. 12).

217 En Estados Unidos hay quienes han llegado al extremo de no enseñar más el caso en sus cursos de Derecho Constitucional (ver Levinson, 2003, p. 553). Al respecto, sugiero ver las interesantes reflexiones de Garay (2009, p. 134), en especial cuando destaca la gran maestría con la que la sentencia está redactada, aspecto en el que coincido con el autor.

218 Así lo había advertido hace más de 130 años un observador tan lúcido como Bryce (1995): "The so-called 'power of anulling an unconstitutional statute' is a duty rather than a power" (p. 224) (la primera edición de la obra data de 1888). Además de todos los trabajos citados previamente que demuestran este punto, sugiero ver también el artículo de Barnett citado en la nota 207. Allí, después de un minucioso análisis acerca de la expresión "judicial power" en el artículo III de la Constitución de 1787, Barnett (2004) concluye: "We are now in a position to understand why the Constitution did not contain a passage reading something like: 'The Supreme Court, and such inferior courts as may be established by Congress, shall have power to nullify a Law enacted by Congress and signed by the President if the Law is unconstitutional.' The evidence from the Constitutional Convention and from the state ratification conventions is overwhelming that the original public meaning of the term 'judicial power' included the power to nullify unconstitutional laws” (p. 138). 
que tiene esa discusión, cosa que comprueba periódicamente todo aquel que se anima a bucear en ese verdadero (y complejo) océano académico.

Para terminar, creo que la revisión del mito de Marbury es útil para recordar cuál es el rol que corresponde a los jueces en un sistema constitucional de tipo estadounidense. Y ese rol no es otro que el que describió John Roberts, actual Chief Justice de la Suprema Corte de los Estados Unidos, durante las audiencias previas a su designación:

Los jueces y los Justices [de la Suprema Corte] son servidores de la ley, y no al revés. Los jueces son como los árbitros deportivos. Los árbitros no hacen las reglas, las aplican. El rol del árbitro y del juez es crítico. Ellos aseguran que todos jueguen bajo las reglas, pero es un rol limitado. ${ }^{219}$

\section{Bibliografía}

Ahumada Ruiz, M. A. (2006). Marbury versus Madison doscientos años (y más) después. Fundamentos, (4), 109-150.

Alexander, L. y Schauer, F. (2000). Defending Judicial Supremacy: A Reply. Constitutional Commentary, 17, 455-482.

Althouse, A. (2010). The Historical Ordinariness of Judicial Review. The George Washington Law Review, 78, 1123-1128.

Amaya, J. A. (2017) Marbury v. Madison. Origen, argumentos y contraargumentos del control judicial de constitucionalidad (5ª ed.). Buenos Aires: Astrea.

Arballo, G. (2003). El Bicentenario del Control de Constitucionalidad. John Marshall y la trastienda de "Marbury vs. Madison”. El Derecho, 201-844.

Aristóteles (1885). Política. En The Politics of Aristotle. (Tomo I). Londres: Oxford at the Clarendon Press.

Barnett, R. E. (2004). The original meaning of the judicial power. Supreme Court Economic Review, 12, 115-138.

Barnett, R. E. (2007). Constitucional Clichés. Capital University Law Review, 36, 493-510.

Barnett, R. E. (2016). Our Republican Constitution. Securing the Liberty and Sovereignty of We the People. Nueva York: Broadside Books.

Baude, E. (2019) The Court, or the Constitution? En Hurd, H. M. (Ed.), Moral Puzzles and Legal Perplexities: Essays on the Influence of Larry Alexander. Nueva York: Cambridge University Press.

219 "Judges and Justices are servants of the law, not the other way around. Judges are like umpires. Umpires don't make the rules, they apply them. The role of an umpire and a judge is critical. They make sure everybody plays by the rules, but it is a limited role" ("Hearings on the Nominations of John G. Roberts, Jr. to be Chief Justice of the Supreme Court of the United States, 2005). 
Beveridge, A. J. (1916) The Life of John Marshall (Tomo I. Frontiersman, Soldier, Lawmaker 1755-1788). Boston: Houghton Mifflin Co.

Bianchi, A. B. (1992). Control de Constitucionalidad. Buenos Aires: Ábaco.

Bianchi, A. B. (2005). Capitalismo y Derecho Constitucional (La experiencia en los Estados Unidos entre la Guerra Civil y la Primera Guerra Mundial). Buenos Aires: Ediciones Rap.

Bilder, M. S. (2006). The Corporate Origins of Judicial Review. Yale Law Journal, 116, 502-566.

Bilder, M. S. (2010). Expounding the Law: Law and Judicial Duty. The George Washington Law Review, 78, 1129-1144.

Beard, C. A. (1913). An Economic Interpretation of the Constitution of the United States. Nueva York: Macmillan.

Belz, H. (1994). History, Theory and the Constitution. Constitutional Commentary, 11, 45-64.

Bickel, A. M. (1962). The Least Dangerous Branch. The Supreme Court at the Bar of Politics (2a ed). New Haven: Yale University Press.

Bidart Campos, G. (2005). Manuel de la Constitución Reformada (Tomo I). Buenos Aires: Ediar.

Bidegain, C. M. (1994). Curso de Derecho Constitucional (Tomo I). Buenos Aires: Abeledo-Perrot.

Boudin, L. B. (1911). Government by Judiciary. Political Science Quarterly, 26(2), 238-270.

Brandeis, L. D. (1916). The Living Law. Illinois Law Review, 10(7), 461-471.

Brown, R. E. (1956). Charles Beard and the Constitution. A critical Analysis of "An Economic Interpretation of the Constitution". Nueva York: W.W. Norton \& Company.

Browning, J. R. y Glenn, B. (1960). Supreme Court Collection at the National Archives. The American Journal of Legal History, 4(3), 241-256.

Bryce, J. (1995). The American Commonwealth. (Tomo I). Indianápolis: Liberty Fund.

Burr, C. H. (1912). Unconstitutional Laws and the Federal Judicial Power. University of Pennsylvania Law Review, 60(9), 624-642.

Carson, H. L. (1895). Judicial Power and Unconstitutional Legislation. The American Law Register and Review, 43, 796-810.

Carson, H. L. (1912). The Historic Relation of Judicial Power to Unconstitutional Legislation. University of Pennsylvania Law Review, 60(10), 687-699.

Casto, W. R. (1995). James Iredell and the American Origins of Judicial Review. Connecticut Law Review, 27(2), 329-363.

Casto, W. R. (1996). Oliver Ellsworth. Journal of Supreme Court History, 1996(2), 73-91.

Casto, W. R. (2009). There Were Great Men Before Agamemnon. Vanderbilt Law Review, 62, 371-405.

Chernow, R. (2004). Alexander Hamilton. Nueva York: The Penguin Press.

Clinton, R. (1989). The Strange History of Marbury v. Madison in the Supreme Court of the United States. Saint Louis University Public Law Review, 8, 13-45.

Connor, H. G. (1912). James Iredell: Lawyer, Statesman, Judge. 1751-1799. University of Pennsylvania Law Review, 60(4), 225-253.

Corwin, E. S. (1906). The Supreme Court and Unconstitutional Acts of Congress. Michigan Law Review, 4, 616-630.

Corwin, E. S. (1909). The Supreme Court and the Fourteenth Amendment. Michigan Law Review, 7, 643-672.

Corwin, E. S. (1911a). The Establishment of Judicial Review - Part I. Michigan Law Review, 9, $102-125$. 
Corwin, E. S. (1911b). The Establishment of Judicial Review - Part II. Michigan Law Review, 9, 283-316.

Corwin, E. S. (1913). Marbury v. Madison and the Doctrine of Judicial Review. Michigan Law Review, 12, 538-572.

Corwin, E. S. (1939). The Posthumous Career of James Madison as Lawyer. American Bar Association Journal, 25, 821-824.

Currie, D. P. (1981). The Constitution in the Supreme Court: 1789-1801. The University of Chicago Law Review, 48(4), 819-885.

Cushman, B. (1998). Rethinking the New Deal Court. The Structure of a Constitutional Revolution. Nueva York: Oxford University Press.

Davis, J. C. B. (1889). Appendix to the Reports of the Decisions of the Supreme Court of the United States. From September 24, 1789, to the end of October Term, 1888. Nueva York: Banks \& Brothers.

Degnan, D. A., S. J. (1998). William Paterson. Small States' Nationalist”. En Gerber, S. D. (Ed.), Seriatim: The Supreme Court Before John Marshall. Nueva York: New York University Press.

Dellinger, W. (1983). The Legitimacy of Constitutional Change: Rethinking the Amendment Process. En Harvard Law Review, 97, 386-432.

Dionisopoulos, P. A. y Peterson, P. (1984). Rediscovering the American Origins of Judicial Review: A Rebuttal to the Views Stated by Currie and Other Scholars. The John Marshall Law Review, 18, 49-76.

Edwards, P. L. (1896). The Federal Judiciary and its Attitude Towards the People. Michigan Law Journal, 5(6), 183-194.

Eisench, E. J. (Ed.). (2006). The Social and Political Thought of American Progressivism. Cambridge: Hacket.

Elliot, C. B. (1890). The Legislatures and the Courts: The Power to Declare Statutes Unconstitutional. Political Science Quarterly, 5(2), 224-258.

Elliot, J. (Ed.). (1836). The Debates in the Several State Conventions, on the Adoption of the Federal Constitution, as recommended by the General Convention at Philadelphia in 1787 (2a ed., Tomos I a IV). Washington.

Engdahl, D. E. (1992). John Marshall's “Jeffersonian” Concept of Judicial Review. Duke Law Journal, 42, 279-339.

Farrand, M. (1908). The First Hayburn Case, 1792. The American Historical Review, 13(2), 281. 285.

Farrand, M. (1913). The Framing of the Constitution of the United States. New Haven: Yale University Press.

Farrand, M. (1937). The Records of the Federal Convention of 1787. (Tomos I y II). New Haven: Yale University Press.

Fernández Segado, F. (2011). La Judicial review en la pre-Marshall Court. Teoría y Realidad Constitucional, (28), 133-178.

Fowler, R. L. (1895). The Origin of the Supreme Court Power in the Federal Constitution. American Law Review, 30(5), 711-725.

Frankel, R. P. (2003). Before Marbury: Hylton v. United States and the Origins of Judicial Review. Journal of Supreme Court History, 28, 1-13.

Garay, A. F. (2009). La enseñanza del caso "Marbury v. Madison”. Academia. Revista Sobre Enseñanza del Derecho, 7(13), 121-136. 
García, M. R. (1863). Estudios sobre la aplicación de la justicia federal norteamericana a la organización constitucional argentina. Florencia: Imprenta de Andrés Bettini.

García de Enterría, E. (2006). La Constitución como Norma y el Tribunal Constitucional (4a ed.). Madrid: Thomson Civitas.

García-Mansilla, M. J. (2009). Estado actual del debate sobre el control judicial de constitucionalidad en los Estados Unidos. Anales de la Academia Nacional de Ciencias Morales y Políticas, XXXV - 2008, Parte II, 303-343.

García-Mansilla, M. J. (2013). Las arbitrariedades del caso "F., A.L.”. Omisiones, debilidades y (ho)(e)rrores del "Roe v. Wade" argentino. Anales de la Academia Nacional de Ciencias Morales y Politicas, XXXIX - 2012, Parte II, 347-385.

García-Mansilla, M. J. (2014). ¿Presunción de Constitucionalidad o Presunción de Libertad? Un análisis desde el artículo 33 de la Constitución Nacional. Anales de la Academia Nacional de Ciencias Morales y Politicas, Tomo XL - 2013, Parte II, 493-606.

García-Mansilla, M. J. (2016). El impeachment al Justice Samuel Chase. El contexto y las consecuencias del caso. En Santiago, A. (h) (Dir.), La responsabilidad de los jueces por el contenido de sus decisiones jurisdiccionales. Marco teórico y análisis de algunos casos paradigmáticos (pp. 185214). Buenos Aires: Thomson Reuters La Ley.

García-Mansilla, M. J. (2018). El proyecto de ley de aborto y la Constitución Nacional. Revista del Colegio de Abogados de la Ciudad de Buenos Aires, 78(1), 16-43.

García-Mansilla, M. J. y Ramírez Calvo, R. (2003). James Madison y la Constitución Nacional. En Homenaje a la Constitución Nacional de 1853 en el sesquicentenario de su sanción (pp. 139. 157). Buenos Aires: Instituto Urquiza de Estudio Históricos, Universidad de Belgrano.

Gargarella, R. (2008). El Contenido Igualitario del Constitucionalismo. Teoría y Crítica del Derecho Constitucional (Tomo I). Buenos Aires: Abeledo-Perrot.

Ghisio, A. y Junco, S. (2019). Derechos Humanos y control de convencionalidad. La recepción de la Corte Suprema tras la reforma constitucional de 1994. Revista Jurídica de la Universidad de San Andrés, 8, 69-102.

Gillman, H. (1997). The Collapse of Constitutional Originalism and the Rise of the Notion of the "Living Constitution" in the Course of American State-Building. Studies in American Political Development, 11, 191-247.

Gerber, S. D. (Ed.). (1988). Seriatim: The Supreme Court Before John Marshall. Nueva York: New York University Press.

Gerber, S. D. (2011). A Distinct Judicial Power. The Origins of an Independent Judiciary, 1606-1787. Nueva York: Oxford University Press.

Gerber, S. D. (2018). The Supreme Court Before John Marshall. University of St. Thomas Law Journal, 14(1), 27-55.

Hall, K. L. (Ed.). (2005). The Oxford Guide to the Supreme Court of the United States. Nueva York: Oxford University Press.

Hall, K. L. y Hall, M. D. (Eds.). (2007). Collected Works of James Wilson (Tomo I). Indianápolis: Liberty Fund.

Hall, M D. (1988). James Wilson. Democratic Theorist and Supreme Court Justice. En Gerber, S. D. (Ed.), Seriatim: The Supreme Court Before John Marshall. Nueva York: New York University Press. 
Hall, M D. (2004). Notes and Documents. James Wilson's Law Lectures. The Pennsylvania Magazine of History and Biography, 128(1), 63-76.

Hamburger, P. A. (1989). The Constitution's Accommodation to Social Change. Michigan Law Review, 88, 239-327.

Hamburger, P. A. (2008). Law and Judicial Duty. Cambridge: Harvard University Press.

Hamburger, P. A. (2010). A Tale of Two Paradigms: Judicial Review and Judicial Duty. The George Washington Law Review, 78, 1162-1177.

Hamilton, A., Madison, J. y Jay, J. (1818). The Federalist, on the New Constitution, written in the year 1788. Washington: Jacob Gideon.

Harrington, J. (1700). The Oceana of James Harrington, and his other works. Londres: Booksellers of London and Westminster.

Haw, J. (1981). Samuel Chase's "Objections to the Federal Government”. Maryland Historical Magazine, 76(3), 272-285.

Higginbotham, D. (Ed.). (1976). The Papers of James Iredell (Tomo II). Raleigh: North Carolina Division of Archives and History.

Hobson, C. F. (1996). The Great Chief Justice. John Marshall and the Rule of Law. Lawrence: University Press of Kansas.

Holt, W. (1998). John Blair. "A Safe and Conscientious Judge”. En Gerber, S. D. (Ed.), Seriatim: The Supreme Court Before John Marshall. Nueva York: New York University Press.

Horwitz, M. J. (1993). The Constitution of Change: Legal Fundamentality Without Fundamentalism. Harvard Law Review, 107, 30-117.

Hume, D. (1882). Of Civil Liberty. En Green, T. H. y Grose, T. H., Essays. Moral, Political, and Literary by David Hume (Tomo I). Londres.

J. H. M. (1870). The Power of the Judiciary to Declare an Act of Congress Void for Unconstitutionality. The American Law Register, 18(10), 585-604.

Jones, A. (1967). Thomas M. Cooley and "Laissez-Faire Constitutionalism": A Reconsideration. Journal of American History, 53(4), 751-771.

Joyce, C. (1985). The Rise of the Supreme Court Reporter: An Institutional Perspective on Marshall Court Ascendancy. Michigan Law Review, 83, 1291-1391.

Kennedy, W. B. (1945). Portrait of the New Supreme Court II. Fordham Law Review, 14(1), 8-36.

Kent, C. A. (1872). Power of the Judiciary to Declare a Law Unconstitutional. The American Law Register, 20(12), 729-737.

Ketcham, R. (1990). James Madison. A biography. Charlottesville: University of Virginia Press.

Klarman, M. J. (2001). How Great Were the "Great" Marshall Court Decisions? Virginia Law Review, 87, 1111-1184.

Koche, A. y Peden, W. (Eds.). (2004). The Life and Selected Writings of Thomas Jefferson. Nueva York: Random House.

Kurland, P. B. y Lerner, R. (Eds.). (1987). The Founders' Constitution (Tomo I). Indianápolis: Liberty Fund.

Lanier, A. S. (1923). Congress and the Supreme Court. The North American Review, 218, 577-588. Laplacette, C. J. (2016). Teoría y Práctica del Control de Constitucionalidad. Buenos Aires: BdeF. Leahy, J. E. (1989). The Constitution is what the judges say it is'. North Dakota Law Review, 65, 491-527. 
Leonard, G. (2006). Iredell Reclaimed: Farewell to Snowiss's History of Judicial Review. Chicago-Kent Law Review, 81, 867-882.

Lerner, M. (1933). The Supreme Court and American Capitalism. Yale Law Journal, 42, 668-701.

Lerner, M. (1939). John Marshall and the Campaign of History. Columbia Law Review, 39, 396-431.

Lerner, R. (1967). The Supreme Court as Republican Schoolmaster. Supreme Court Review, 1967, 127-180.

Levinson, S. (2003). Why I Do Not Teach Marbury (Except to Eastern Europeans) and Why You Shouldn't Either. Wake Forest Law Review, 38, 553-578.

Levy, L. W. (1999). Origins of the Bill of Rights. New Haven: Yale University Press.

Lewis, W. D. (1895). The Constitutionality of the Income Tax. The American Law Register and Review, 43(3), 189-195.

Linares Quintana, S. V. (1978). Tratado de la Ciencia del Derecho Constitucional Argentino y Comparado (2a ed., Tomo III). Buenos Aires: Plus Ultra.

Loewenstein, K. (1964). Teoría de la Constitución. Barcelona: Ariel.

Löffler, E. (2016). John Marshall ¿Padre del control de constitucionalidad? Acerca de algunos precedentes que habrían inspirado su decisión en el caso "William Marbury versus James Madison”. Revista de Derecho Público de Venezuela, 147/148, 153-171.

Lowrie, W. y Franklin, W. S. (Eds.). (1834). American Sates Papers. Documents, Legislative and Executive, of the Congress of the United States, Class X. Miscellaneous (Vol. 1). Washington: Gales \& Seaton.

Madison, J. (1999). Writings. Nueva York: The Library of America.

Mahoney, D. J. (1982). A Historical Note on Hodgson v. Bowerbank. The University of Chicago Law Review, 49, 725-740.

Marcus, M. (2019). Wilson as a Justice. The Georgetown Journal of Law Ë Public Policy, 17, 147-166.

Marcus, M. y Perry, J. R. (Eds.). (1985). The Documentary History of the Supreme Court of the United States, 1789-1800 (Tomo I). Nueva York: Columbia University Press.

Marcus, M. y Tier, R. (1988). Hayburn's Case: A Misinterpretation of Precedent. Wisconsin Law Review, 1988, 527-546.

McKenna, M. C. (2002). Franklin Roosevelt and the Great Constitutional War. The court-packing crisis of 1937. Nueva York: Fordham University Press.

McRee, G. J. (1858). Life and Correspondence of James Iredell, one of the Associate Justices of the Supreme Court of the United States (Tomo II, D). Nueva York: Appleton and Company.

Nino, C. S. (1992). Fundamentos de derecho constitucional. Análisis filosófico, jurídico y politológico de la práctica constitucional. Buenos Aires: Astrea.

O'Connor, S. D. (2004). The Majesty of the Law. Reflections of a Supreme Court Justice. Nueva York: Random House.

Paine, T. (2005).Common Sense and other writings. Nueva York: Barnes \& Noble.

Parker, J. (1896). The Supreme Court and its Constitutional Duty and Power. American Law Review, 30, 357-364.

Patterson, P. C. (1939). James Madison and Judicial Review. California Law Review, 28, 22-33.

Paulsen, M S. (2003). The Irrepressible Myth of Marbury. Michigan Law Review, 101, 2706-2743.

Pennoyer, S. (1895). The Income Tax Decision, and the Power of the Supreme Court to Nullify Acts of Congress. American Law Review, 29, 550-558. 
Pennoyer, S. (1896). The case of Marbury v. Madison. American Law Review, 30, 188-202.

Pérez Manrique, R. C. La experiencia de los Máximos Tribunales nacionales en el control de convencionalidad y diálogo jurisprudencial: el caso de Uruguay. Derecho Internacional de los Derechos Humanos, Número Especial de Jurisprudencia Argentina, t. 2016-III, 4-12.

Prakash, S. B. y Yoo, J. C. (2003). The Origins of Judicial Review. The University of Chicago Law Review, 70, 887-982.

Presser, S. B. (2002). Some Alarming Aspects of the Legacies of Judicial Review and of John Marshall. William and Mary Law Review, 43, 1495-1511.

Presser, S. B. (2009). Samuel Chase: In Defense of the Rule of Law and Against the Jeffersonians. Vanderbilt Law Review, 62(2), 349-370.

Presser, S. B. y Hurley, B. B. (1984). Saving God's Republic: The Jurisprudence of Samuel Chase. University of Illinois Law Review, 1984, 771-822.

Rakove, J. N. (1992). James Madison and the Bill of Rights: A Broader Context. Presidential Studies Quarterly, 22(4), 667-677.

Ramírez Calvo, R. (1995). La Constitución reformada y los tratados internacionales. La Ley, t. 1995-B, 773-778.

Rey Martínez, F. (2007). Una relectura del Dr. Bonham's Case y de la aportación de Sir Edward Coke a la creación de la judicial review. Revista Española de Derecho Constitucional, (81), 163. 181.

Ritz, W. J. (1958). United States v. Yale Todd (U.S. 1794). Washington and Lee Law Review, 15, 220-231.

Ritz, W. J. (1990). Rewriting the History of the Judiciary Act of 1789. Exposing Myths, Challenging Premises, and Using New Evidence. Norman: University of Oklahoma Press.

Rosen, J. (2007). The Supreme Court. The Personalities and Rivalries that Defined America. Nueva York: Holt \& Co.

Rosenberg, L. B. (1969). Constitutional Supremacy: An Early Advocate of Judicial Review. Duquesne Law Review, 7(4), 515-541.

Ross, W. G. (1994). A Muted Fury: Populists, Progressives, and Labor Unions Confront the Courts, 1890-1937. Nueva Jersey: Princeton University Press.

Schwartz, B. (1963). A Commentary on the Constitution of the United States (Tomo I). Nueva York: The Macmillan Co.

Schwartz, B. (1993). A History of the Supreme Court. Nueva York: Oxford University Press.

Sheehan, C. A. y McDowell, G. L. (1998). Friends of the Constitution. Writings of the "Other" Fedralists. 1787-1788. Indianápolis: Liberty Fund.

Sherman, G. E. (1905). The case of John Chandler v. The Secretary of War. Yale Law Journal, $14,431-451$.

Smith, G. H. (2013). The System of Liberty. Themes in the History of Classical Liberalism. Nueva York: Cambridge University Press.

Sola, J. V. (2001). Control Judicial de Constitucionalidad. Buenos Aires: Abeledo-Perrot.

Spooner, L. (1845). The Unconstitutionality of Slavery. Boston: Bela Marsh.

Surrency, E. C. (Ed.). (1961a). The Minutes of the Supreme Court of the United States - 1789. 1806. The American Journal of Legal History, 5(1), 67-86.

Surrency, E. C. (Ed.). (1961b). The Minutes of the Supreme Court of the United States - 1789. 1806. The American Journal of Legal History, 5(2), 166-196. 
Surrency, E. C. (Ed.). (1963a). The Minutes of the Supreme Court of the United States - 1789. 1806. The American Journal of Legal History, 7(1), 63-82.

Surrency, E. C. (Ed.). (1963b). The Minutes of the Supreme Court of the United States - 17891806. The American Journal of Legal History, 7(3), 246-271.

Taft, W. H. (1895). Recent Criticism of the Federal Judiciary. The American Law Register and Review, 43(9), 576-610.

Tiedeman, C. G. (1895). The Income Tax Decisions as an Object Lesson in Constitutional Construction. The Annals of the American Academy of Political and Social Science, 6, 72-83.

Treanor, W. M. (1994). The Case of the Prisoners and the Origins of Judicial Review. University of Pennsylvania Law Review, 143, 491-570.

Treanor, W. M. (2005). Judicial Review before Marbury, 58, 455-562.

Tricket, W. (1906). The Great Usurpation. American Law Review, 40(3), 356-376.

Tucker, St. G. (1803). Appendix to Volume First. Part First of Blackstone's Commentaries. En Blackstone's Commentaries: with note of reference, to the Constitution and Laws, of the Federal Government of the United States, and the Commonwealth of Virginia (Tomo I). Filadelfia: William Young Birch \& Abraham Small.

Varnum, J. M. (1787). The Case, Trevett Against Weeden: On Information and Complaint, for refusing Paper Bills in Payment for Butcher's Meat, in Market, at Par with Specie: Tried before the Honourable Superior Court, in the County of Newport, September Term, 1786. Providence: impreso por John Carter.

Warren, C. (1922). The Supreme Court in United States History (Tomo I). Boston: Little, Brown \& Co. Warren, C. (1923). Earliest Cases of Judicial Review of State Legislation by Federal Courts. Yale Law Journal, 32, 15-28.

Watson, B. C. S. (2009). Living Constitution, Dying Faith. Progressivism and the New Science of Jurisprudence. Wilmington: Isi Books.

Wexler, N. (2006). In the Beginning: The First Three Chief Justices. University of Pennsylvania Law Review, 154, 1373-1419.

White, G. E. (2010). The Lost Origins of American Judicial Review. The George Washington Law Review, 78(6), 1145-1161.

Whittington, K. E. (2009). Judicial Review Before the Civil War. The Georgetown Law Journal, 97, 1257-1331.

Whittington, K. E. (2019). Repugnant Laws. Judicial Review of Acts of Congress from the Founding to the present. Lawrence: University Press of Kansas.

\section{Fuentes}

Annals of the Congress of the United States (1792). House of Representatives, Vol. 3. Annals of the Congress of the United States (1794). House of Representatives, Vol. 4. Annals of the Congress of the United States (1798). House of Representatives, Vol. 8. Annals of the Congress of the United States (1802). House of Representatives, Vol. 11. Arguments and Judgment of the Major's Court of the City of New York, in a cause between Elizabeth Rutgers and Joshua Waddington (1784). Nueva York: Samuel Loudon.

"Hearings on the Nominations of John G. Roberts, Jr. to be Chief Justice of the Supreme Court of the United States, September 12-15, 2005, Senate Committee. on the Judiciary", 
109th Congress, p. 55 (2005). https://www.govinfo.gov/content/pkg/GPO-CHRG-ROBERTS/pdf/GPO-CHRG-ROBERTS-2-3-1.pdf.

Letters and other writings of James Madison (1865). (Vol. I, 1769-1793). Filadelfia: J. B. Lippincott \& Co.

The Constitution of North Carolina, adopted December 17, 1776; and the amendments thereto, submitted to the people by the convention which assembled at Raleigh, June 4, 1835; together with an ordinance for carrying the same into effect. (1835). Raleigh: J. Gales \& Son.

The Papers of Thomas Jefferson. Retirement Series (2018). (Tomo 15, septiembre 1819 a mayo 1820). Nueva Jersey: Princeton University Press.

\section{Fuentes inéditas}

Carta de Edmund Randolph a George Washington, 5 de abril de 1792, Biblioteca del Congreso de los Estados Unidos, George Washington Papers, Series 4, General Correspondence, 1697-1799. https://www.loc.gov/resource/mgw4.101_1002_1003/?st=gallery.

Carta de Edmund Randolph a George Washington, 5 de agosto de 1792, Biblioteca del Congreso de los Estados Unidos, George Washington Papers, Series 4, General Correspondence, 1697-1799. https://www.loc.gov/resource/mgw4.102_0336_0341/?sp=2.

National Gazette, (16 de abril de 1792). Chronicling America: Historic American Newspapers, Vol. I, $\mathrm{N}^{\circ} 49$, p. 195. Biblioteca del Congreso de los Estados Unidos. https://chroniclingamerica. loc.gov/lccn/sn83025887/1792-04-16/ed-1/seq-3/.

\section{Legislación citada}

United States Statutes at Large, Vol. 1, 2 ${ }^{\text {nd }}$. Congress, 1". Session, Ch. 11, p. 243 (1792) ("An Act to provide for the settlement of the Claims of Widows and Orphans barred by the limitations heretofore established, and to regulate the Claims to Invalid Pensions").

United States Statutes at Large, Vol. 1, 2 $2^{\text {nd }}$. Congress, $2^{\text {nd }}$ Session, Ch. 17, p. 324 (1793) ("An Act to regulate the Claims to Invalid Pensions").

United States Statutes at Large, Vol. 1, $3^{\text {rd }}$ Congress, $1^{\text {st }}$ Session, Ch. 57, p. 392 ("An Act concerning Invalids”) (1794).

\section{Jurisprudencia citada}

\section{Court of Appeals of Virginia}

Commonwealth v. Caton, 8 Va. (4 Call.) 5 (1782).

\section{Major's Court of the City of New York}

Rutgers v. Waddington, s/d (1784).

\section{Superior Court of Rhode Island}

Trevett $v$. Weeden, s/d (1786). 


\section{Supreme Court of North Carolina}

Bayard v. Singleton, 1 N.C. 5 (1787).

\section{United Sates Circuit Court of Virginia}

United States v. Callender, 25 F. Cas. 239, No. 14, 709 (C.C. Va.) (1800).

\section{Supreme Court of the United States}

Aurora v. United States, 11 U.S. (7 Cranch) 382 (1813).

Benner v. Porter, 50 U.S. (9 How.) 235 (1850).

Brailsford v. Georgia, no reportado (1798).

Calder v. Bull, 3 U.S. (Dall.) 386 (1798).

Chisholm v. Georgia, 2 U.S. (2 Dall.) 419 (1793).

Cooper v. Aaron, 358 U.S. 1 (1958).

Dickerson v. United States, 530 U.S. 428 (2000).

Dred Scott v. Sanford, 60 U.S. (19 How.) 393 (1857).

Hayburn's case, 2 U.S. (2 Dall.) 409 (1792).

Hollingsworth v. Virginia, 3 U.S. (3 Dall.) 378 (1798).

Hylton v. United States, 3 U.S. (3 Dall.) 171 (1796).

John Chandler v. Secretary of War, no reportado (1794).

Loughborough v. Blake, 18 U.S. (5 Wheat.) 317 (1820).

Lylte v. Arkansas, 50 U.S. (9 How.) 314 (1850).

Marbury v. Madison, 5 U.S. (1 Cranch) 137 (1803).

Mayor of New Orleans v. United States, 35 U.S. (10 Pet.) 662 (1836).

McNulty v. Batty, 51 U.S. (10 How.) 72 (1850).

Mossman v. Higginson, 4 U.S. 12 (1800).

Moultrie v. Georgia, no reportado (1798).

Mugler v. Kansas, 123 U.S. 623 (1887).

N.J. Steam Navigation Co. v. Merchants' Bank of Boston, 47 U.S. (6 How.) 344 (1848).

New York Trust Co. v. Eisner, 256 U.S. 345 (1921).

Parsons v. Bedford, 28 U.S. (3 Pet.) 433 (1830).

Pennoyer v. Neff, 95 U.S. 714 (1878).

Pollard v. Hagan, 44 U.S. (3 How.) 212 (1845).

Pollock v. Farmers' Loan 87 Trust Company, 157 U.S. 429 (1895).

Propeller Genesee Chief v. Fitzhugh (The Genesee Chief), 53 U.S. (12 How.) 443 (1851).

Reynolds v. M'Arthur, 27 U.S. (2 Pet.) 417 (1829).

South Carolina v. Baker, 485 U.S. 505 (1988).

United States v. Ferreira, 54 U.S. (13 How.) 40 (1852).

United States v. La Vengeance, 3 U.S. 297 (3 Dall.) (1796).

United States v. Percheman, 32 U.S. (7 Pet.) 51 (1833).

United States v. Phelps, 33 U.S. (8 Pet.) 700 (1834).

United States v. Smith, 18 U.S. (5 Wheat.) 153 (1820). 
United States v. Yale Todd, no reportado (1794).

Vanhorne's Lessee v. Dorrance, 2 U.S. (2 Dall.) 304 (1795).

Ware v. Hylton (3 U.S. (3 Dall.) 199 (1796).

Waring v. Clarke, 46 U.S. (5 How.) 441 (1847).

Wayman v. Southard, 23 U.S. (10 Wheat.) 1 (1825).

Wheaton v. Peters, 33 U.S. (8 Pet.) 591 (1834).

\section{Corte Interamericana de Derechos Humanos}

Caso Almonacid Arellano y otros vs. Chile, Excepciones Preliminares, Fondo, Reparaciones y Costas, sentencia del 26 de septiembre de 2006, Serie C, Nº 154. 
